NUREG/CR-6382

PNL-10747

\title{
Comparisons of ASTM Standards Cited in the NRC Standard Review Plan, NUREG-0800, and Related Documents
}

Manuscript Completed: September 1995

Date Published: October 1995

Prepared by

A. R. Ankrum, K. L. Bohlander, E. R. Gilbert, R. A. Pawlowski, J. B. Spiesman

Pacific Northwest Laboratory

Richland, WA 99352

G. Suh, NRC Project Manager

Prepared for

Division of Inspection and Support Programs

Office of Nuclear Reactor Regulation

U.S. Nuclear Regulatory Commission

Washington, DC 20555-0001

NRC Job Code L2013 


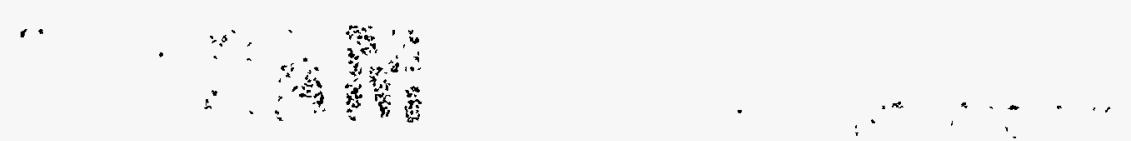




\section{DISCLAIMER}

This report was prepared as an account of work sponsored by an agency of the United States Government. Neither the United States Government nor any agency thereof, nor any of their employees, makes any warranty, express or implied, or assumes any legal liability or responsibility for the accuracy, completeness, or usefulness of any information, apparatus, product, or process disclosed, or represents that its use would not infringe privately owned rights. Reference herein to any specific commercial product, process, or service by trade name, trademark, manufacturer, or otherwise does not necessarily constitute or imply its endorsement, recommendation, or favoring by the United States Government or any agency thereof. The views and opinions of authors expressed herein do not necessarily state or reflect those of the United States Government or any agency thereof. 


\section{DISCLAIMER}

Portions of this document may be illegible in electronic image products. Images are produced from the best available original document. 
This report provides the results of comparisons of the cited and latest versions of ASTM standards cited in the NRC Standard Review Plan for the Review of Safety Analysis Reports for Nuclear Power Plants (NUREG 0800) and related documents. The comparisons were performed by Battelle Pacific Northwest Laboratories in support of the NRC's Standard Review Plan Update and Development Program. Significant changes to the standards, from the cited version to the latest version, are described and discussed in a tabular format for each standard. Recommendations for updating each citation in the Standard Review Plan are presented. Technical considerations and suggested changes are included for related regulatory documents (i.e., Regulatory Guides and the Code of Federal Regulations) citing the standard. The results and recommendations presented in this document have not been subjected to NRC staff review. 


\begin{tabular}{|c|c|c|c|}
\hline \multicolumn{3}{|c|}{ Abstract } & \multirow{2}{*}{$\frac{\text { iii }}{\text { vii }}$} \\
\hline & ive $S$ & mary & \\
\hline \multicolumn{3}{|c|}{ Acronyms } & $\mathrm{ix}$ \\
\hline \multirow[t]{7}{*}{1} & \multicolumn{2}{|c|}{ Introduction } & $1-1$ \\
\hline & 1.1 & Background & $1-1$ \\
\hline & 1.2 & Purpose and Anticipated Use of This Document & $1-1$ \\
\hline & 1.3 & Contents of This Document & $1-1$ \\
\hline & 1.4 & Methodology & $1-2$ \\
\hline & 1.5 & Summary of Results & 1-3 \\
\hline & 1.6 & Current Status of the ASTM Standard Comparisons & $1-8$ \\
\hline \multirow[t]{7}{*}{2} & \multicolumn{2}{|c|}{ Straightforward Comparisons } & $2-1$ \\
\hline & 2.1 & $\begin{array}{l}\text { ASTM A262 Standard Practices for Detecting Susceptibility to Intergranular Attack } \\
\text { in Austenitic Stainless Steels }\end{array}$ & $2.1-1$ \\
\hline & 2.2 & ASTM C512 Standard Test Method for Creep of Concrete in Compression & $2.2-1$ \\
\hline & 2.3 & ASTM D2854 Standard Test Method for Apparent Density of Activated Carbon & $2.3-1$ \\
\hline & 2.4 & $\begin{array}{l}\text { ASTM D2862 Standard Test Method for Particle Size Distribution of Granular } \\
\text { Activated Carbon }\end{array}$ & $2.4-1$ \\
\hline & 2.5 & $\begin{array}{l}\text { ASTM E23 Standard Test Methods for Notched Bar Impact Testing of Metallic } \\
\text { Materials }\end{array}$ & $2.5-1$ \\
\hline & 2.6 & $\begin{array}{l}\text { ASTM E208 Standard Test Method for Conducting Drop-Weight Test to Determine } \\
\text { Nil-Ductility Transition Temperature of Ferritic Steels }\end{array}$ & $2.6-1$ \\
\hline \multirow[t]{4}{*}{3} & \multicolumn{2}{|c|}{ Problematic Comparisons } & $3-1$ \\
\hline & 3.1 & ASTM D1587 Standard Test Method for Thin-Walled Tube Sampling of Soils & $3.1-1$ \\
\hline & 3.2 & $\begin{array}{l}\text { ASTM D3286 Standard Test Method for Gross Calorific Value of Coal and Coke by } \\
\text { the Isoperibol Bomb Calorimeter }\end{array}$ & $3.2-1$ \\
\hline & 3.3 & ASTM E11 Standard Specification for Wire Cloth Sieves for Testing Purposes & $3.3-1$ \\
\hline
\end{tabular}




\section{EXECUTIVE SUMMARY}

\section{Background and Purpose}

This report provides the results of comparisons of the cited and latest versions of ASTM standards cited in the Nuclear Regulatory Commission (NRC) Standard Review Plan for the Review of Safety Analysis Reports for Nuclear Power Plants (NUREG 0800) and associated Regulatory Guides and Code of Federal Regulations (CFR) sections. The comparisons were performed by Battelle Pacific Northwest Laboratories in support of the NRC's Standard Review Plan Update and Development Program (SRP-UDP) under JCN L-2013, and will be used by the NRC to evaluate whether the SRP citations to ASTM standards should be updated. The report will also afford nuclear plant vendors, utilities, and the public an opportunity to review and provide comments on the rationale and supporting documentation for updating citations to ASTM standards in the SRP and associated Regulatory Guides and CFR sections. The NRC will publish a Federal Register Notice of availability of this document and solicit public comments on whether ASTM standard citations should be updated, and if so, what exceptions should be included with the citation.

\section{Contents}

This document presents the comparisons of selected ASTM standards cited in the SRP and associated Regulatory Guides and CFR sections. Straightforward comparisons are presented first, followed by problematic comparisons, e.g., those requiring further analysis or involving a number of significant changes. "Significant," as used herein, is defined as that which the NRC has relied upon to establish a position in the regulatory document, and specifically, in the case of SRP citations, that which is relied upon as the basis for SRP acceptance criteria.

A separate section has been prepared for each ASTM standard comparison. Each section is comprised of three parts. Part I lists the sources and locations of the citations of the standard in the SRP and associated Regulatory Guides and CFR sections and briefly describes the context of the citation.

Part II presents a detailed comparison of the cited version of the standard to the latest version in a tabular format and discusses the ramifications of updating the citation to the latest version.

Part III presents further consideration of the effects of the changes described in Part II on the SRP and associated Regulatory Guides and CFR sections citing the standard. Recommendations for updating each citation in the SRP to the latest version are presented. Technical considerations and suggested changes are also included for related regulatory documents citing the ASTM standard in Part III.

\section{METHODOLOGY}

ASTM standards were selected for comparison based on the following criteria:

1. Comparisons are considered for standards cited in SRP Sections, Regulatory Guides and Title 10 of the CFR. Comparisons are not performed on standards cited in other documents unless specifically requested by the NRC. 
2. Comparisons are performed for standards cited in the SRP if the citation is determined to have safety significance, i.e., if it provides a basis for SRP acceptance criteria.

3. Comparisons are performed for standards cited in the Regulatory Guides that have potential impact on associated SRP sections, unless the citation is a secondary reference or the standard is cited in a portion of the Regulatory Guide which is not applicable to the associated SRP section.

4. Comparisons are performed for standards cited in the $10 \mathrm{CFR}$ if the citation has potential impact on the associated SRP section(s).

A side by side comparison of the cited and latest versions is made to identify any changes that are "significant" as defined above. Significant differences between the cited and latest versions are presented and discussed in tabular form in Part II. To facilitate evaluation of the citations and presentation of the results, significant differences are classified into one of five change types, as listed below:

1. new or changed requirements affecting established NRC positions and requirements,

2. new or changed requirements not addressed by established NRC positions and requirements,

3. new or changed requirements allowing more flexibility,

4. deleted or relaxed requirements, and

5. new or changed requirements implementing or adding detail to established NRC regulatory positions.

Part III presents further consideration of the effects of the changes described in Part II on the SRP and associated regulatory documents citing the standard. Those changes classified as types $1-4$ are summarized in this section. Evaluations and recommendations regarding action on the specific citations are also presented.

\section{Results}

An overall summary of results is given in Section 1.5 of the Introduction. In this summary, recommendations and suggestions are tabulated by ASTM standard for each of the documents citing the standard. Results of the ASTM standard comparisons show that updating of the SRP relative to its citation of and reliance on ASTM standards for acceptance criteria involves coordination with revisions to other regulatory documents, especially the NRC's

Regulatory Guides. In many cases, citations can be updated to cite the latest version of the standard, but usually with exceptions necessary to preserve established regulatory positions. These exceptions can be addressed in a corresponding Regulatory Guide that may already exist and which may delineate exceptions to the cited version of the ASTM standard. Alternatively, the exceptions could be addressed in some other reference document or included in the SRP. For several of the ASTM standards, considerable analysis is required for proper evaluation and eventual endorsement of more recent versions of ASTM standards than those currently cited in the SRP. 


\section{ACRONYM LIST}

$\begin{array}{ll}\text { ALAG } & \text { Automotive Industry Action Group } \\ \text { ASTM } & \text { American Society for Testing Materials } \\ \text { ANSI } & \text { American National Standards Institute } \\ \text { ASME } & \text { American Society of Mechanical Engineers } \\ \text { ASTM } & \text { American Society for Testing and Materials } \\ \text { BTP } & \text { Branch Technical Position } \\ \text { CFR } & \text { Code of Federal Regulations } \\ \text { MT } & \text { Mill Treated } \\ \text { NFPA } & \text { National Fire Protection Association } \\ \text { NRC } & \text { Nuclear Regulatory Commission } \\ \text { NUREG } & \text { NRC Technical Report Designation } \\ \text { PNL } & \text { Pacific Northwest Laboratory } \\ \text { SRP } & \text { Standard Review Plan } \\ \text { SRP-UDP } & \text { Standard Review Plan Update \& Development Program }\end{array}$


Background information on the Nuclear Regulatory Commission (NRC) Standard Review Plan Update Development Program (SRP-UDP) effort to evaluate citations to ASTM standards is provided in Section 1.1. The purpose and anticipated use of this document are described in Section 1.2. The contents of the document are described in Section 1.3. Section 1.4 describes the methodology for selecting the standards and performing the comparisons. Section 1.5 provides a summary of the results of the comparisons. The current status of the comparisons is discussed in Section 1.6.

\subsection{Background}

A large number of nuclear industry consensus codes and standards are cited and referenced in regulatory documents such as the NRC Standard Review Plan for the Review of Safety Analysis Reports for Nuclear Power Plants NUREG-0800 (SRP), Regulatory Guides, the Code of Federal Regulations (CFR), NRC Bulletins, Information Notices, Circulars, Generic Letters, and Policy Statements. A list of these citations and references is available as NUREG/CR-5973, "Codes and Standards and Other Guidance Cited in Regulatory Documents," prepared by Pacific Northwest Laboratory (PNL) as part of the SRP-UDP.

As noted in NUREG/CR-5973, only a small percentage of the codes and standards cited in the regulatory documents are the latest versions of those codes and standards. To assess the regulatory impact of revising the citations to the latest versions of the codes and standards, comparisons of the cited and latest ${ }^{(1)}$ versions of selected standards have been performed by PNL as part of the SRP-UDP under JCN L-2013.

\subsection{Purpose and Anticipated Use of This Document}

It is anticipated that the information and recommendations in this ASTM comparison topical report will be used by the NRC to evaluate whether the SRP citations to ASTM standards should be updated. This report will also afford nuclear plant vendors, utilities, and the public an opportunity to review and comment on the rationale and supporting documentation for updating citations to ASTM standards in the SRP and associated Regulatory Guides and CFR sections.

\subsection{Contents of this Document}

This document presents the comparisons of selected ASTM standards cited in the SRP and associated Regulatory Guides and CFR sections. The basis for selection of these standards for comparison is discussed in Subsection 1.4, Methodology. Straightforward comparisons are presented first. Problematic comparisons (e.g., those requiring further analysis, and/or those involving a number of significant changes) are presented last. was chosen as representative of the citations for that standard for comparison to the "latest" version. The term "latest" refers to that version of the ASTM standard which was used as the reference version for comparison to the cited version. In most cases the "latest" version is the version in effect at the time the comparison was performed. Any exceptions to this will be addressed in the specific sections on the affected standards. 
A separate section has been prepared for each ASTM standard comparison. Each section is comprised of three parts. Part I lists the sources and location of the citations of the standard in the SRP and associated Regulatory Guides and CFR sections and briefly describes the context of the citation.

Part II presents a detailed comparison of the cited version of the standard to the latest version in a tabular format and discusses the ramifications of updating the citation to the latest version.

Part III presents further consideration of the effects of the changes described in Part II on the SRP and associated Regulatory Guides and CFR sections citing the standard. Those changes classified as types $1-4$ are summarized in this section. Evaluation and recommendations regarding action on the citation are also presented in Part III. Technical considerations and suggested changes are also included for related regulatory documents citing the ASTM standard.

\subsection{Methodology}

The methodology for selection of standards for comparison as well as guidelines for performing the comparisons are described below.

\subsubsection{Selection of Standards}

ASTM standards were selected for comparison based on the following criteria:

1. Standard comparisons are considered for citations from SRP Sections, Regulatory Guides, and Title 10 of the CFR. Comparisons are not performed on standards cited in other documents unless they are specifically requested by the NRC.

2. Comparisons are performed for standards cited in the SRP if the citation is determined to have "safety significance," i.e., if it provides a basis for SRP acceptance criteria.

3. Comparisons are performed for standards cited in the Regulatory Guides that have potential impact on associated SRP sections unless:

a. The citation is a secondary reference and the performance of a comparison is not justified, or

b. The standard is cited in a portion of the Regulatory Guide which is not applicable to the associated SRP Section.

4. Comparisons are performed for standards cited in the 10 CFR if the citation has potential impact on the associated SRP(s). 


\subsubsection{Performance of Standard Comparisons}

A side-by-side comparison of the cited and latest versions is made to identify changes that are "significant." "Significant," as used herein, is defined as that which the NRC has relied upon to establish a position in the regulatory document, and specifically, in the case of SRP citations, that which is relied upon as the basis for SRP acceptance criteria. For example, a change to a standard is deemed to be "significant" if the revised wording, deletion, or addition is not consistent with regulatory requirements or recommendations. Any change that constitutes a relaxation of standard requirements is considered to be significant. Similarly, added or deleted requirements are considered significant unless the change clearly and explicitly aligns the standards with latest regulatory criteria. Changes that use a modified method, test, or process to achieve the same results are also considered significant until they are reviewed and accepted by the NRC. Significant changes identified in the side-by-side comparison are presented and discussed in Part II of the section for that ASTM standard.

To facilitate evaluation of the citations and presentation of the evaluation, significant differences between the cited and latest versions are classified into one of five change types, listed below:

1. new or changed requirements affecting established NRC positions and requirements,

2. new or changed requirements not addressed by established NRC positions and requirements,

3. new or changed requirements allowing more flexibility,

4. deleted or relaxed requirements, and

5. new or changed requirements implementing or adding detail to established NRC regulatory positions.

Part III presents further consideration of the effects of the changes described in Part II on the SRP and associated Regulatory Guides and CFR sections citing the standard. Those changes classified as types 1 - 4 are summarized in this section. Evaluations and recommendations regarding action on the SRP citations are presented in Part III. Technical considerations and suggested changes are also included for related regulatory documents citing the ASTM standard.

\subsection{Summary of Results}

The results of the ASTM standard comparisons are summarized in this section. In this summary, recommendations, considerations, and suggestions are tabulated by ASTM standard for those regulatory documents citing the standard. The results of the straightforward comparisons are presented first, followed by the results for the problematic comparisons. 


\section{STRAIGHTFORWARD COMPARISONS}

\begin{tabular}{|c|c|c|c|c|}
\hline $\begin{array}{l}\text { ASTM } \\
\text { Standard }\end{array}$ & $\begin{array}{c}\text { Cited } \\
\text { Version }\end{array}$ & $\begin{array}{c}\text { Latest } \\
\text { Version }\end{array}$ & $\begin{array}{l}\text { Report } \\
\text { Section }\end{array}$ & Citing Document(s) \\
\hline \multirow[t]{2}{*}{ A262 } & $1979 *$ & 1993 & 2.1 & $\begin{array}{l}\text { SRP } 4.5 .1 \text { ( } 2 \text { places), } \\
\text { SRP 5.2.3 ( } 1 \text { place), } \\
\text { SRP 6.1.1 (2 places), } \\
\text { Regulatory Guide } 1.44 \text { ( } 2 \text { places), } \\
\text { Regulatory Guide } 1.84 \text { (1 place) }\end{array}$ \\
\hline & \multicolumn{4}{|c|}{$\begin{array}{l}\text { Except for the citation of A262-1970 in Regulatory Guide } 1.84 \text {, consider updating } \\
\text { the citations of A262 to the } 1993 \text { version. The significant changes primarily } \\
\text { expand the applicability of the standard to additional alloys not covered in the } \\
\text { cited version of the standard and add a new testing practice. The citation of } \\
\text { A262-1970 in Regulatory Guide } 1.84 \text { is for historical purposes and should be } \\
\text { retained and not updated. Code Case N-238, in which A262-1970 is cited, has } \\
\text { been annulled by action of the ASME and is considered as deleted from the list } \\
\text { of acceptable Code Cases by the NRC. }\end{array}$} \\
\hline \multirow[t]{2}{*}{ C512 } & 1976 & 987 (R94) & 2.2 & Regulatory Guide 1.35 .1 (1 place) \\
\hline & \multicolumn{4}{|c|}{$\begin{array}{l}\text { A subsection added to the } 1987 \text { version to describe a new procedure for } \\
\text { introducing the effect of temperature on the elastic and inelastic properties of } \\
\text { concrete was the only significant change identified. This added subsection does } \\
\text { not appear to conflict with the regulatory positions stated in Appendix A of } \\
\text { Regulatory Guide 1.35.1. Consider updating the citation of C512-1976 with C512- } \\
1987 \text { (R94). }\end{array}$} \\
\hline D2854 & 1970 & 1989 (R93) & 2.3 & Regulatory Guide 1.140 (1 place) \\
\hline
\end{tabular}

Consider updating the citation to the latest version. No significant changes were identified.

D2862 $1970 \quad 1992 \quad 2.4 \quad$ Regulatory Guide 1.140 (2 places)

D2862 is cited for the test method for particle size distribution of granular activated carbon. The added reference to ASTM E300 for collecting and preparing granular activated carbon samples was the only significant change identified. This change represents advances in the sampling technology. Consider updating the citation to the latest version.

KEY TO NOTES

Date of cited standard is inferred from the context of the citation in the regulatory document. 


\section{ASTM Cited Latest Report \\ $\underline{\text { Standard Version } \text { Version Section }}$ \\ $\begin{array}{lllll}\text { E23 } & 1981^{*} & 1993 \mathrm{a} & 2.5 & \text { SRP } 5.2 .3 \text { (1 place) }\end{array}$ \\ The changes to the requirements, specifications, methods and implementation of E23 increase testing controls and do not appear to conflict with the regulatory requirements of SRP 5.2.3. Consider updating the citation to the latest version. \\ E208 1969* \\ 1991 \\ 2.6 SRP 5.2 .3 ( 1 place), \\ SRP 5.3 .2 in BTP MTEB 5-2 (1 place), SRP 5.4.1.1 (2 places), \\ SRP 10.2 .3 (2 places)}

E208 is cited as the standard method for conducting drop-weight tests to determine nil-ductility transition temperature of ferritic steels. Changes identified to be significant appear to increase requirements for test specimen preparation, electrode specifications, and testing procedures. Consider updating the citation to the latest version. 


\section{PROBLEMATIC COMPARISONS}

\begin{tabular}{|c|c|c|c|c|}
\hline $\begin{array}{l}\text { ASTM } \\
\text { Standard }\end{array}$ & $\begin{array}{c}\text { Cited } \\
\text { Version }\end{array}$ & $\begin{array}{l}\text { Latest } \\
\text { Version }\end{array}$ & $\begin{array}{l}\text { Report } \\
\text { Section }\end{array}$ & Citing Document(s) \\
\hline \multirow[t]{2}{*}{ D1587 } & 1967 & 1983 & 3.1 & Regulatory Guide 1.132 (2 places) \\
\hline & \multicolumn{4}{|c|}{$\begin{array}{l}\text { Most significant changes identified appear to increase requirements for boring } \\
\text { tubes. Regulatory Guide } 1.132 \text { provides guidance for boring tubes in those cases } \\
\text { with reduced requirements in the } 1983 \text { version. Consider updating the citation to } \\
\text { the latest version. }\end{array}$} \\
\hline D3286 & 1973 & 1991a & 3.2 & $\begin{array}{l}\text { SRP 9.5.1 in BTP CMEB } 9.5-1 \text { (1 place), } \\
\text { Regulatory Guide } 1.120 \text { ( } 2 \text { places) }\end{array}$ \\
\hline
\end{tabular}

Updating BTP CMEB 9.5-1 to cite the latest version of the standard (ASTM D3286 - 1991a) is not recommended based on the change of applicability from solid fuels in the cited version to only coal and coke in the latest version. The existing citation of ASTM D3286 (1973) in references of BTP CMEB 9.5-1 appears to have been carried over in the revision to the previous version of the BTP (BTP ASB 9.5-1). However, the text in BTP ASB 9.5-1 that was associated with the standard was deleted in BTP CMEB 9.5-1. This deleted text allowed alternatives to non-combustible interior finishes based in part on material heat release as determined using ASTM D3286 (1973). BTP CMEB 9.5-1 states that interior finishes should be non-combustible. Therefore it is recommended that the references to ASTM D3286 -1973 be deleted from BTP CMEB 9.5-1, because the reference does not support any current positions or guidance contained within the BTP.

Updating Regulatory Guide 1.120 to cite the latest version of the standard (ASTM D3286 - 1991a) is not recommended based on the change of applicability from solid fuels in the cited version to only coal and coke in the latest version. Regulatory Guide 1.120, Revision 1, was issued for comment in November 1977. If the NRC decides to revise Regulatory Guide 1.120 in the future, it is expected that the existing version of the Regulatory Guide would require considerable updating to reflect current regulatory positions and guidance that have been developed or evolved since the Regulatory Guide was issued. If such an update to Regulatory Guide 1.120 occurs, consideration should be given to assessing the continued applicability of ASTM D3286 (1973) in light of more recent or updated standards such as NFPA 259, "Standard Test Method for Potential Heat of Building Materials." 


\begin{tabular}{|c|c|c|c|c|}
\hline $\begin{array}{l}\text { ASTM } \\
\text { Standard }\end{array}$ & $\begin{array}{c}\text { Cited } \\
\text { Version }\end{array}$ & $\begin{array}{c}\text { Latest } \\
\text { Version } \\
\end{array}$ & $\begin{array}{l}\text { Report } \\
\text { Section }\end{array}$ & Citing Document(s) \\
\hline E11 & 1970 & 1987 & 3.3 & Regulatory Guide 1.140 (1 place) \\
\hline & \multicolumn{4}{|c|}{$\begin{array}{l}\text { E11 is cited for specifications for wire cloth sieves for determining particle size } \\
\text { distribution of activated carbon. The changes that were identified as being } \\
\text { significant do not appear to reduce the requirements for testing activated carbon } \\
\text { applicable to Regulatory Guide } 1.140 \text {. Consider updating the citation to the latest } \\
\text { version. }\end{array}$} \\
\hline
\end{tabular}




\subsection{Current Status of the ASTM Standard Comparisons}

The ASTM standard comparisons presented herein have been prepared by PNL and have not been reviewed by the NRC staff. Therefore the suggestions and recommendations contained in this report are the work of PNL, and their implementation is contingent upon NRC acceptance of justifications for revisions to the SRP and other regulatory documents citing the ASTM standards. It is anticipated that PNL's recommendations for SRP citations in the straightforward standard comparisons presented in Section 2 will be implemented, subject to NRC staff review and NRC evaluation of public comments. Further NRC staff review and evaluation, including evaluation of public comments, will be needed prior to updating the SRP citations for the problematic standard comparisons presented in Section 3 of this report. Comments and suggestions concerning the comparisons are solicited, specifically on whether an update to the latest version is appropriate and on any necessary exceptions and qualifications required to update citations to the latest version. Please reply by mail to Gene Y. Suh, SRP-UDP Engineer (JCN L-2013), at the following address:

Mr. Gene Y. Suh

U. S. Nuclear Regulatory Commission

Office of Nuclear Reactor Regulation

Mail Stop 0-12 E4

Washington, DC 20555-0001 
Section 2

STRAIGHTFORWARD COMPARISONS 


\subsection{ASTM Standard A262 Comparison}

This section presents a comparison of the version of ASTM A262 cited in the Standard Review Plan (SRP) and associated Regulatory Guides and Code of Federal Regulation (CFR) sections with the latest version of the standard, in support of the Nuclear Regulatory Commission's (NRC's) Standard Review Plan Update and Development Program (SRP-UDP).

\section{CITED STANDARD:}

ASTM A262 (version not specified), "Standard Recommended Practices for Detecting Susceptibility to Intergranular Attack in Stainless Steels." The 1979 version of ASTM A262 was in effect in July 1981 when SRP Section 4.5.1 was issued, and is used for this comparison.

\section{LATEST STANDARD:}

ASTM A262-93, "Standard Practices for Detecting Susceptibility to Intergranular Attack in Austenitic Stainless Steels"

\section{CONTENTS}

I. REGULATORY CITATIONS $\ldots \ldots \ldots \ldots \ldots \ldots \ldots \ldots \ldots \ldots \ldots \ldots \ldots \ldots \ldots \ldots \ldots \ldots \ldots \ldots \ldots \ldots \ldots \ldots \ldots .1-2$

SRP Citations $\ldots \ldots \ldots \ldots \ldots \ldots \ldots \ldots \ldots \ldots \ldots \ldots \ldots \ldots \ldots \ldots \ldots \ldots \ldots \ldots \ldots \ldots \ldots \ldots \ldots \ldots .1-2$

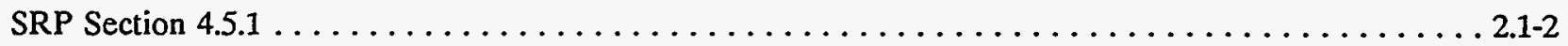

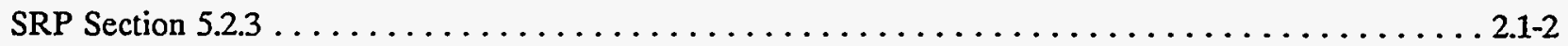

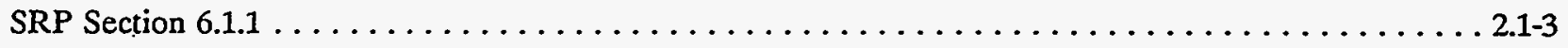

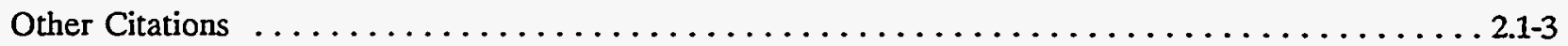

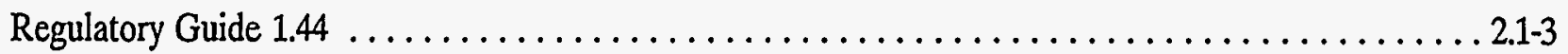

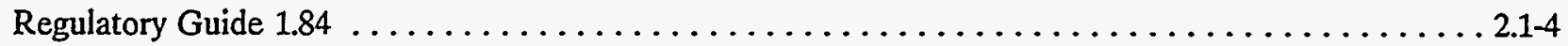

II. CITED VS. LATEST STANDARD DIFFERENCES $\ldots \ldots \ldots \ldots \ldots \ldots \ldots \ldots \ldots \ldots \ldots \ldots \ldots \ldots \ldots \ldots .1-4$

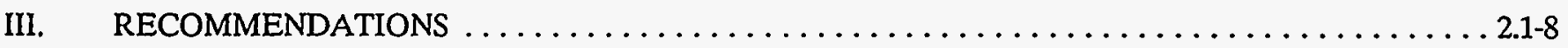

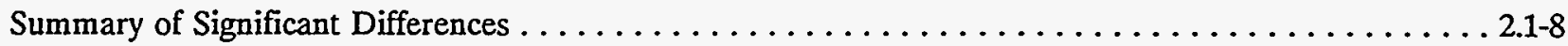

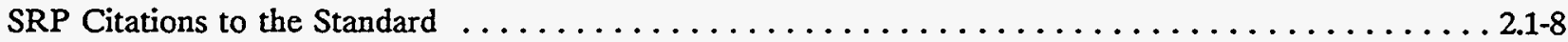

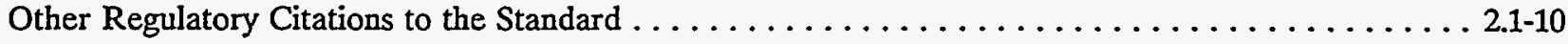




\section{REGULATORY CITATIONS}

This part of the comparison identifies specific citations to ASTM A262 in the SRP and associated Regulatory Guides and 10 CFR sections. Recommendations on the disposition of these citations based on the results of this standard comparison are presented in Part III, Recommendations.

\section{SRP Citations}

The SRP citations addressed here do not reference a specific version (year) for ASTM A262. A review of the contents of the 1968, 1979, and 1982 versions of ASTM A262 indicates that there were no major changes to the contents of the standard over the period of 1968 to 1979. With the exception of adding Subsection 36.1.5 to the 1979 version, changes were editorial in nature, with some addition of detail and reformatting (e.g., the figures and tables were moved to the end of the standard in 1970). Subsection 36.1.5, added to the 1979 version, provides guidance for applying the bend test (Practice E) to austenitic steel plates 0.1875 inch thick or more. Each of the three SRP sections is dated July 1981. ASTM A262 was revised in July 1979, then revised again in July 1981, approved on July 31, 1981, and published in November 1981. The 1979 version of ASTM A262 was in effect in July 1981, the date of the three SRP sections. Therefore, this analysis assumes that the cited standard was ASTM A262-1979.

\section{SRP Section 4.5.1}

Revision/Title: Rev. 2, July 1981, "Control Rod Drive Structural Materials"

Locations: ASTM A262 is cited in two subsections: III and VI.

Context: In subsection III. Review Procedures, ASTM A262 is cited for verification of non-sensitization of materials and testing the qualification welds for degree of sensitization. In VI. References, ASTM A262 Practices $\mathrm{A}$ and $\mathrm{E}$ is listed as Reference 6.

\section{SRP Section $\mathbf{5 . 2 . 3}$}

Revision/Title: Rev. 2, July 1981, "Reactor Coolant Pressure Boundary Materials"

Locations: ASTM A262 is cited in subsection VI.

Context: In subsection VI. References, ASTM A262 Practice E is listed as Reference 5 for detecting susceptibility to intergranular attack in stainless steels. 


\section{SRP Section 6.1.1}

Revision/Title: Rev. 2, July 1981, "Engineered Safety Features Materials"

Locations: ASTM A262 is cited in two subsections: III and VI.

Context: In subsection III. Review Procedures, ASTM A252 is cited for verification of nonsensitization of the materials and the qualification of welding procedures. In subsection VI. References, ASTM A262 Practice $\mathrm{E}$ is listed as Reference 3 for detecting susceptibility to intergranular attack in stainless steel.

\section{Other Citations}

The regulatory guide citations addressed here reference the 1968 and 1970 versions for ASTM A262. A review of the contents of the 1968, 1979, and 1982 versions of ASTM A262 indicates that there were no major changes to the contents of the standard over the period of 1968 to 1979. With the exception of adding Subsection 36.1 .5 to the 1979 version, changes were editorial in nature, with some addition of detail and reformatting (e.g., the figures and tables were moved to the end of the standard in 1970). Subsection 36.1.5, added to the 1979 version, provides guidance for applying the bend test (Practice E) to austenitic steel plates 0.1875 inch thick or more. Three SRP sections that cite a nonspecific version of ASTM A262 are dated July 1981. ASTM A262 was revised in July 1979, then revised again in July 1981, approved on July 31, 1981, and published in November 1981. The 1979 version of ASTM A262 was in effect in July 1981, the date of the three SRP sections. Therefore, this analysis uses ASTM A262-1979 for the cited standard.

\section{Regulatory Guide 1.44}

Revision/Title: Rev. 2, July 1981, "Control of the Use of Sensitized Steel"

Locations: ASTM A262-1970 is cited in two subsections: B and C.

Context: In subsection B. Discussion, Practice E of ASTM A252-70 and the accompanying screening test Practice $A$ are cited as suitable tests for verifying non-susceptibility of material to intergranular corrosion. In subsection C. Regulatory Position, Practice A or E of ASTM A262 are specified to show non-sensitization in austenitic stainless steel. 


\section{Regulatory Guide 1.84}

Revision/Title: Rev. 28 (April 1992), Rev. 20 (July 1993), and Rev. 30 (October 1994), "Design and Fabrication Code Case Acceptability ASME Section III Division 1 "

Locations: ASTM A262-1970 is cited in subsection C. Regulatory Position.

Context: In subsection C. Regulatory Position, ASTM A262 is cited in Code Case N-238 which has been annulled by the ASME and is considered by the NRC to be deleted from the list of acceptable code cases. The citation of ASTM A262-1970 is retained in Code Case N-238 for historical purposes.

\section{CITED VS. LATEST STANDARD DIFFERENCES}

This part of the comparison presents those changes from the cited version (1979) to the latest version (1993) identified for ASTM A262. Many of these changes involve formatting, editorial and grammatical differences. Others involve clarification (e.g., the addition of a figure or illustration) and have no effect on requirements. Those differences between the cited and latest versions of ASTM A262 which are judged to be significant and warranted further investigation relative to the technical and regulatory effects of their citation in regulatory documents are tabulated and discussed on the following pages.

To facilitate review and consideration of their effects on ASTM A262 citations in regulatory documents, significant differences between the cited and latest versions are classified into the following change types:

1. new or changed requirements affecting established NRC positions and requirements,

2. new or changed requirements not addressed by established NRC positions and requirements,

3. new or changed requirements allowing more flexibility,

4. deleted or relaxed requirements, and

5. new or changed requirements adding detail to established NRC regulatory positions.

Further consideration of the effects of the changes presented in this section on the SRP and associated Regulatory Guides and CFR sections that cite ASTM A262 is provided in the Part III, Recommendations, of this section. Those differences classified as change types 1-4 are summarized in Part III. 


\begin{tabular}{|c|c|c|c|}
\hline \multicolumn{4}{|c|}{ CITED VS. LATEST STANDARD DIFFERENCES: ASTM A262 } \\
\hline $\begin{array}{l}\text { Section } \\
\text { cited \& } \\
\text { [latest] }\end{array}$ & $\frac{\text { Significant Changes }}{\text { cited \& [latest] }}$ & $\begin{array}{l}\text { Type of } \\
\text { Change }\end{array}$ & $\begin{array}{c}\cdot \\
\text { Discussion }\end{array}$ \\
\hline $\begin{array}{c}\text { Table } 1 \\
\text { [Table 1] }\end{array}$ & $\begin{array}{l}\text { Chromium carbide detectability in "316LN, } 316 \mathrm{~N} \text {," } \\
\text { was added for the Nitric-Hydrofluoric Acid Test. } \\
\text { AISI Steel Types "201, 202, 301, 304H, and 316H" } \\
\text { and "Chromium carbide in 201, 202, 301" were } \\
\text { added for the Copper-Copper Sulfate-Sulfuric Acid } \\
\text { Test (24 h in boiling solution). The "Copper- } \\
\text { Copper Sulfate-50 \% Sulfuric Acid Testing Boiling } \\
\text { Solution," its applicability to "ACI: CF-3M and CF- } \\
8 \mathrm{M} \text {," and "Chromium carbide detectability in: CF- } \\
\text { 3M, CF-8M" were added. }\end{array}$ & 1 & $\begin{array}{l}\text { The identification of additional alloys that can be } \\
\text { tested with the procedures of this standard and the } \\
\text { addition of Practice } F \text { appear to be a significant } \\
\text { expansion to the applicability of this standard. }\end{array}$ \\
\hline $\begin{array}{c}2.2 \\
{[3.2]}\end{array}$ & $\begin{array}{l}\text { The "16\%" specification was added to the Copper- } \\
\text { Copper Sulfate-Sulfuric Acid Test, and "Practice F } \\
\text { - Copper-Copper Sulfate- } 50 \% \text { Sulfuric Acid Test" } \\
\text { was added. }\end{array}$ & 1 & $\begin{array}{l}\text { The identification of the copper-copper sulfate-16\% } \\
\text { sulfuric acid test is not significant because it is only a } \\
\text { change in title to the same test in the } 1979 \text { version; } \\
\text { however, the added provision for using the oxalic } \\
\text { acid etch test to screen specimens intended for } \\
\text { testing in Practice F - copper-copper sulfate- } 50 \% \\
\text { sulfuric acid test appears to be a significant } \\
\text { expansion to the standard. }\end{array}$ \\
\hline
\end{tabular}




\begin{tabular}{|c|c|c|c|}
\hline \multicolumn{3}{|c|}{$\begin{array}{l}\text { STRAIGHTFORWARD } \\
\text { COMPARISONS }\end{array}$} & \multirow[b]{2}{*}{ NCES: ASTM A262 } \\
\hline \multicolumn{3}{|c|}{ CITED VS. LATEST STANDARD DIFFERENCES: ASTM A262 } & \\
\hline $\begin{array}{l}\text { Section } \\
\text { cited \& } \\
\text { [latest] }\end{array}$ & $\begin{array}{c}\text { Significant Changes } \\
\text { cited \& [latest] }\end{array}$ & $\begin{array}{l}\text { Type of } \\
\text { Change }\end{array}$ & Discussion \\
\hline $\begin{array}{l}\text { Table 2 } \\
\text { [Table 2] }\end{array}$ & $\begin{array}{l}\text { The "16\% " specification was added to the Copper- } \\
\text { Copper Sulfate-Sulfuric Acid Test and "Practice F- } \\
\text { Copper-Copper Sulfate-50 \% Sulfuric Acid Test" } \\
\text { was added. AISI Grade No. 201, } 202,301,304 \mathrm{H} \text {, } \\
\text { and } 316 \mathrm{H} \text { were added for applicability of the } \\
\text { Practice E Test. ACI Grade No. CF-8M and CF- } \\
3 \mathrm{M} \text { were added for applicability of the Practice F } \\
\text { Test. }\end{array}$ & 1 & $\begin{array}{l}\text { The addition of the } 16 \% \text { specification is not } \\
\text { significant because it is only a change in title to the } \\
\text { same test in the } 1979 \text { version; however, the addition } \\
\text { of Practice } F \text { and the addition of other alloys that } \\
\text { this standard is applicable to appear to be significant } \\
\text { expansions to this standard. }\end{array}$ \\
\hline $\begin{array}{c}2.4 \\
{[3.4]}\end{array}$ & $\begin{array}{l}\text { The } 1993 \text { version adds "and stabilized grades" " } 321 \text {, } \\
\text { and } 347 . " \text { The primary fahrenheit and secondary } \\
\text { centigrade temperature units were interchanged. } \\
\text { Specification of the most commonly used } \\
\text { sensitization temperature in primary centigrade } \\
\text { units was added. }\end{array}$ & 1 & $\begin{array}{l}\text { The presentation of the metric temperature units as } \\
\text { the primary units for use in the latest version of the } \\
\text { standard is not significant; however, the addition of } \\
\text { Alloys } 321 \text { and } 347 \text { for testing by this standard } \\
\text { appears to be a significant expansion to the } \\
\text { requirements. }\end{array}$ \\
\hline $\begin{array}{c}6.2 \\
{[7.2]}\end{array}$ & $\begin{array}{l}\text { Applicability of the test was extended to "and in } \\
\text { cast chromium-nickel-molybdenum stainless steels } \\
\text { (CF-3M, C6-8M, and CG-3M)." }\end{array}$ & 1 & $\begin{array}{l}\text { The extension of the applicability of the standard to } \\
\text { additional alloys appears to be a significant } \\
\text { expansion of the standard. }\end{array}$ \\
\hline $\begin{array}{l}\text { None } \\
{[7.6]}\end{array}$ & Practice $F$ was added. & 1 & $\begin{array}{l}\text { The addition of Practice } F \text { appears to be a } \\
\text { significant expansion of this standard. There are no } \\
\text { similar provisions in the cited version. }\end{array}$ \\
\hline $\begin{array}{c}7.1 .1 \\
{[8.1 .1]}\end{array}$ & $\begin{array}{l}\text { "The ferric sulfate-sulfuric acid test will detect } \\
\text { intergranular corrosion associated with sigma phase } \\
\text { in the cast stainless steels CF-3M and CF-8M." was } \\
\text { added. }\end{array}$ & 1 & $\begin{array}{l}\text { The extension of the applicability of the standard to } \\
\text { additional alloys appears to be a significant } \\
\text { expansion of the standard. }\end{array}$ \\
\hline
\end{tabular}




\begin{tabular}{|c|c|c|c|}
\hline \multicolumn{4}{|c|}{ CITED VS. LATEST STANDARD DIFFERENCES: ASTM A262 } \\
\hline $\begin{array}{l}\text { Section } \\
\text { cited \& } \\
\text { [latest] }\end{array}$ & $\begin{array}{c}\text { Significant Changes } \\
\text { cited \& [latest] }\end{array}$ & $\begin{array}{l}\text { Type of } \\
\text { Change }\end{array}$ & Discussion \\
\hline $\begin{array}{c}7.2 \\
{[8.2]}\end{array}$ & $\begin{array}{l}\text { The phrase, "and cast austenitic stainless steels } \\
\text { containing molybdenum such as Types CF-8M, CF- } \\
3 \mathrm{M}, \mathrm{CG}-8 \mathrm{M} \text {, and CG-3M," was added. }\end{array}$ & 1 & $\begin{array}{l}\text { The extension of the applicability of the standard to } \\
\text { additional alloys appears to be a significant } \\
\text { expansion of the standard. }\end{array}$ \\
\hline $\begin{array}{c}\text { Table } 6 \\
\text { [Table 6] }\end{array}$ & $\begin{array}{l}\text { The sulfuric acid content was identified as } 16 \% \text { in } \\
\text { the title and in the footnote. Alloys } 201,202,301 \text {, } \\
304 \mathrm{H} \text { and } 316 \mathrm{H} \text { were added. }\end{array}$ & 1 & $\begin{array}{l}\text { The identification of the } 16 \% \text { acid is for clarity (i.e., } \\
\text { the cited version refers to } 16 \% \text { in Note } 24 \text { ) and does } \\
\text { not add new requirements. However, the } \\
\text { identification of the applicability of the method to } \\
\text { additional alloys is a significant expansion of the } \\
\text { standard. }\end{array}$ \\
\hline $\begin{array}{l}\text { None } \\
\text { [Practice } \\
\text { F] }\end{array}$ & The new test, Practice F, was added. & 1 & $\begin{array}{l}\text { The added Practice } \mathrm{F} \text { is a new application for this } \\
\text { standard. There is no similar provision in the } 1989 \\
\text { version. }\end{array}$ \\
\hline
\end{tabular}




\section{RECOMMENDATIONS}

This part of the comparison summarizes significant differences (identified in Part II) between the cited and latest versions of the standard and addresses their regulatory effects on the citing documents. Those changes in the standard that only added detail to existing requirements are not included in the summary of significant differences. The regulatory citations to ASTM A262 (identified in Part I) are evaluated based on the significant differences between the cited and latest versions of this standard. Citations in the SRP are evaluated first, followed by citations in associated Regulatory Guides and 10 CFR sections. Recommendations concerning the updating of these citations as they relate to the SRP-UDP are also included in this part of the comparison.

\section{Summary of Significant Differences}

Differences between the 1979 and 1993 versions that appear to be significant include the identification of additional alloys to which test procedures have been found to be applicable, and the addition of a new quantitative test, Practice F, "Copper-Copper Sulfate - 50\% Sulfuric Acid Test for Detecting Susceptibility to Intergranular Attack in Molybdenum-Bearing Cast Austenitic Stainless Steels." These changes appear to be significant because they expand the scope of the standard to include an additional test method, and additional alloys to which the standard is applicable. Subject to NRC analysis of these differences, consideration should be given to revising SRP citations to endorse ASTM A262-93 as a replacement for ASTM A262 (version not specified).

\section{SRP Citations to the Standard}

\section{SRP Section 4.5.1, Rev. 2, "Control Rod Drive Structural Materials" (July 1981)}

Subject to NRC analysis of the apparently significant differences identified, consideration should be given to revising SRP Section 4.5.1 to endorse ASTM A262-93 as a replacement for ASTM A262 (version not specified).

SRP 4.5.1

Paragraph

III. REVIEW PROCEDURES

2. Austenitic

Stainless Steel

Components

VI. REFERENCES

\section{Recommendation}

Standard ASTM A262 (version not specified) is cited in Section III.c REVIEW PROCEDURES for austenitic stainless steel components in SRP Section 4.5.1. The latest version, ASTM A262-1993, includes guidance on applicability of the tests to additional alloys and introduces Practice $F$ as a new quantitative test. Consider revising SRP 4.5.1 Section III.c REVIEW PROCEDURES to replace ASTM A262-1979 with the latest version, ASTM A262-1993.

Standard ASTM A262 is also included in the Section VI REFERENCES to SRP 4.5.1. The version listed in Section VI should be maintained to agree with the version cited in Section III. 
SRP Section 5.2.3, Rev. 2, "Reactor Coolant Pressure Boundary Materials" (July 1981)

Subject to NRC analysis of the identified significant differences, consideration should be given to replace the reference to Standard ASTM A262 (version not specified), Practice E, in SRP Section 5.2.3 with the latest version, ASTM A262-1993, Practice E.

SRP 5.2.3

Paragraph $\quad$ Recommendation

VI. REFERENCES Standard ASTM A262 (version not specified), Practice E, is included in the REFERENCE to SRP 5.2.3, but is not cited in the text. The latest version, ASTM A262-1993 includes guidance on applicability of Practice $E$ to additional alloys. Consider revising SRP 5.2.3 to reference ASTM A262-1993, Practice E in Section VI.

\section{SRP Section 6.1.1, Rev. 2, "Engineered Safety Features Materials" (July 1981)}

Subject to NRC analysis of the identified significant differences, consideration should be given to replace the reference to Standard ASTM A262 (version not specified), in SRP Section 6.1.1 with the latest version, ASTM A2621993.

SRP 6.1.1

Paragraph

III. $\underline{\text { REVIEW }}$ PROCEDURES

A. Primary Review Area

VI. REFERENCES $\underline{\text { Recommendation }}$

Standard ASTM A262 (version not specified) is cited in subsection III. REVIEW PROCEDURES, A. Primary Review Area of SRP Section 6.1.1. The latest version, ASTM A262-1993 includes guidance on applicability of the tests to additional alloys and includes a new quantitative test. Consider revising SRP 6.1.1 Section III.A REVIEW PROCEDURES to replace ASTM A262 with the latest version, ASTM A262-1993, that is maintained by ASTM.

Standard ASTM A262 is also included in the Section VI REFERENCES to SRP 6.1.1. The version listed in Section VI should be maintained to agree with the version cited in Section III. 


\section{Other Regulatory Citations to the Standard}

Regulatory Guide 1.44, Rev. 2, "Control of the Use of Sensitized Steel" (July 1981)

Subject to NRC analysis of the identified significant differences consideration should be given to replace the reference to Standard ASTM A262 1968, in Regulatory Guide 1.44 Revision 0 (May 1973) with the latest version, ASTM A2621993.

Regulatory Guide

1.44 Paragraph

B. DISCUSSION

C. REGULATORY POSITION

3. No Title $\underline{\text { Recommendation }}$

Practice E of ASTM A262-70, "Copper Copper Sulfate--Sulfuric Acid Test," and the accompanying screening test Practice A, "Oxalic Acid Etch Test," are considered suitable tests in Section B. DISCUSSION of Regulatory Guide 1.44 Rev. 0 (May 1973) for verifying non-susceptibility of the material to intergranular stress corrosion. The latest version, ASTM A262-1993 includes guidance on applicability of the tests to additional alloys and includes a new quantitative test. Consider revising Section B of Regulatory Guide 1.44 to cite ASTM A262-1993.

Section C. REGULATORY POSITION 3. of Regulatory Guide 1.44 endorses ASTM A262-70, "Recommended Practices for Detecting Susceptibility to Intergranular Attack in Stainless Steel," Practices A or E to verify non-sensitization of unstabilized, austenitic stainless steel of the AISI Type 3XX series used for components that are part of (1) the reactor coolant pressure boundary, (2) systems required for reactor shutdown, (3) systems required for emergency core cooling, and (4) reactor vessel internals that are relied upon to permit adequate core cooling for any mode of normal operation or under credible postulated accident conditions.

The latest version, ASTM A262-1993 includes guidance on applicability of the tests to additional alloys and includes a new quantitative test. Consider revising Regulatory Guide 1.44 Section C REGULATORY POSITION 3. to replace ASTM A262-70 with the latest version, ASTM A262-1993. 
Regulatory Guide 1.84, Rev. 30), "Design and Fabrication Code Case Acceptability ASME Section III Division 1" (October 1994)

Consideration should be given for Regulatory Guide 1.84 to continue to cite ASTM A262-1970 in Code Case N-238. Regulatory Guide 1.84 indicates that Code Case N-238 was annulled by ASME on January 1, 1982. As stated in Regulatory Guide 1.84, Regulatory Position C.2., the NRC considers that code cases that were endorsed by the NRC in a prior version of Regulatory Guide 1.84 and were later annulled by action of the ASME should be considered as deleted from the list of acceptable Code Cases as of the date of the ASME action that approved the annulment. The retention of the record of Code Case N-238 in Regulatory guide 1.84 appears to be for historical purposes. Updating the citation of ASTM A262-1970 to ASTM A262-1993 in Regulatory Guide 1.84 to support Code Case N-238 that was annulled in 1982 and considered as deleted by the NRC would be inappropriate.

Regulatory Guide 1.84 Paragraph C. REGULATORY POSITION

2. No Title

\section{Recommendation}

The retention of the record of Code Case N-238 in Regulatory Guide 1.84 appears to be for historical purposes. Updating the citation of ASTM A262-1970 to ASTM A262-1993 in Regulatory Guide 1.84 to support Code Case N-238 that was annulled in 1982 and considered as deleted by the NRC appears to be inappropriate. Consider retaining the citation of ASTM A262-1970 in Code Case N-238 for Regulatory Guide 1.84 . 


\subsection{ASTM Standard C512 Comparison}

This section presents a comparison of the version of C512 cited in the Standard Review Plan (SRP) and associated Regulatory Guides and Code of Federal Regulation (CFR) sections with the latest version of the standard, in support of the Nuclear Regulatory Commission's (NRC's) Standard Review Plan Update and Development Program (SRP-UDP).

\section{CITED STANDARD:}

ANSI/ASTM C512-1976, "Standard Test Method for Creep of Concrete in Compression"

\section{LATEST STANDARD:}

ASTM C512-1987 (R94), "Standard Test Method for Creep of Concrete in Compression"

\section{CONTENTS}

$\underline{\text { Page }}$

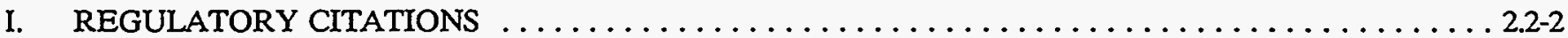

SRP Citations $\ldots \ldots \ldots \ldots \ldots \ldots \ldots \ldots \ldots \ldots \ldots \ldots \ldots \ldots \ldots \ldots \ldots \ldots \ldots \ldots \ldots \ldots \ldots \ldots \ldots \ldots \ldots \ldots \ldots \ldots .2-2$

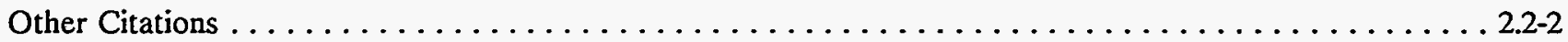

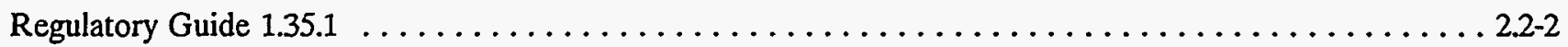

II. CITED VS. LATEST STANDARD DIFFERENCES $\ldots \ldots \ldots \ldots \ldots \ldots \ldots \ldots \ldots \ldots \ldots \ldots \ldots \ldots \ldots \ldots \ldots \ldots \ldots .2 .2$

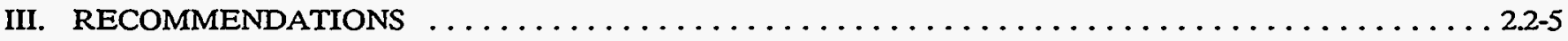

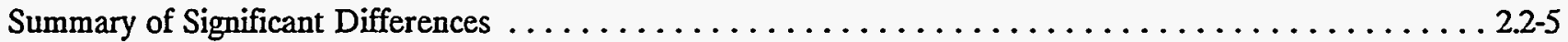

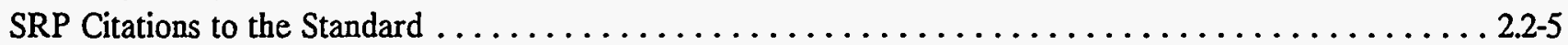

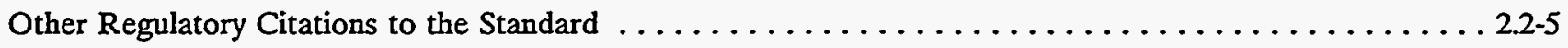




\section{REGULATORY CITATIONS}

This part of the comparison identifies specific citations to ASTM C512-1976 in the SRP and associated Regulatory Guides and 10 CFR sections. Recommendations on the disposition of these citations based on the results of this standard comparison are presented in Part III, Recommendations.

\section{SRP Citations}

None

Other Citations

Regulatory Guide 1.35.1

Revision/Title: Rev. 0, July 1990, "Determining Prestressing Forces for Inspection of Prestressed Concrete Containments"

Location: Regulatory Guide 1.35.1 lists ANSI/ASTM C512-76 in the Reference subsection as Reference 15.

Context: ANSI/ASTM C512-76 is listed as Reference 15 in the Reference subsection in Regulatory Guide 1.35.1. Reference 15 is cited in Appendix A, last paragraph, for the performance of short-term creep tests, results of which provide input to the recommended creep formula. Appendix A provides six specific provisions to be used with ASTM C512. The review of concrete containment designs is covered in SRP Section 3.8.1, "Concrete Containment," Revision 1, dated July 1981.

\section{CITED VS. LATEST STANDARD DIFFERENCES}

This part of the comparison presents those changes from the cited version (1976) to the latest version (1987 (R94)) identified for ASTM C512. Many of these changes involve formatting, editorial and grammatical differences. Others involve clarification (e.g., the addition of a figure or illustration) and have no effect on requirements. Those differences between the cited and latest versions of ASTM C512 which are judged to be significant and warranted further investigation relative to the technical and regulatory effects of their citation in regulatory documents are tabulated and discussed on the following pages. 
To facilitate review and consideration of their effects on ASTM C512 citations in regulatory documents, significant differences between the cited and latest versions are classified into the following change types:

1. new or changed requirements affecting established NRC positions and requirements,

2. new or changed requirements not addressed by established NRC positions and requirements,

3. new or changed requirements allowing more flexibility,

4. deleted or relaxed requirements, and

5. new or changed requirements adding detail to established NRC regulatory positions.

Further consideration of the effects of the changes presented in this section on the SRP and associated Regulatory Guides and CFR sections that cite ASTM C512 is provided in the Part III, Recommendations, of this section. Those differences classified as change types 1-4 are summarized in Part III. 


\begin{tabular}{|c|l|c|c||}
\hline \multicolumn{3}{|c|}{ CITED VS. LATEST STANDARD DIFFERENCES: ASTM C512 } \\
\hline $\begin{array}{c}\text { Section } \\
\text { cited \& } \\
\text { [latest] }\end{array}$ & \multicolumn{1}{|c|}{$\begin{array}{c}\text { Significant Clianges } \\
\text { cited \& [latest] }\end{array}$} & $\begin{array}{l}\text { Type of } \\
\text { Change }\end{array}$ & \\
\hline $\begin{array}{c}\text { None } \\
{[6.3]}\end{array}$ & $\begin{array}{l}\text { A new procedure was added for introducing the } \\
\text { effect of temperature on the elastic and inelastic } \\
\text { properties of concrete. }\end{array}$ & 1 & $\begin{array}{l}\text { The addition of a new procedure in the } 1987 \text { version } \\
\text { to enable evaluation of the effect of temperature on } \\
\text { the elastic and inelastic properties of concrete adds } \\
\text { new procedures and requirements. }\end{array}$ \\
\hline
\end{tabular}




\section{RECOMMENDATIONS}

This part of the comparison summarizes significant differences (identified in Part II) between the cited and latest versions of the standard and addresses their regulatory effects on the citing documents. The regulatory citations to ASTM C512 (identified in Part I) are evaluated based on the significant differences between the cited and latest versions of this standard. Citations in the SRP are evaluated first, followed by citations in associated Regulatory Guides and 10 CFR sections. Recommendations concerning the updating of these citations as they relate to the SRP-UDP are also included in this part of the comparison.

\section{Summary of Significant Differences}

Only one significant change was identified. A subsection was added to the 1987 (R94) version to describe a new procedure for introducing the effect of temperature on the elastic and inelastic properties of concrete. This added subsection does not appear to conflict with the regulatory positions stated in Appendix A of Regulatory Guide 1.35.1.

ASTM C512-1987 (R94) does not appear to have any significant changes that would cause it to be unacceptable to replace ANSI/ASTM C512-1976 as a reference in Regulatory Guide 1.35.1. Consideration should be given for Regulatory Guide 1.35.1 to reference ASTM C512-1987 (R94), "Standard Test Method for Creep of Concrete in Compression," as a replacement for ANSI/ASTM C512-1976, "Standard Test Method for Creep of Concrete in Compression."

\section{SRP Citations to the Standard}

None

Other Regulatory Citations to the Standard

Regulatory Guide 1.35.1, Rev. 0, "Determining Prestressing Forces for Inspection of Prestressed Concrete Containments" (July 1990)

Reg. Guide Location

Reference 15

\section{Suggested Changes}

Consider replacing the reference to ANSI/ASTM C512-1976 with ASTM C512-1987 (R94). 


\subsection{ASTM Standard D2854 Comparison}

This section presents a comparison of the version of ASTM D2854 cited in the Standard Review Plan (SRP) and associated Regulatory Guides and Code of Federal Regulation (CFR) sections with the latest version of the standard, in support of the Nuclear Regulatory Commission's (NRC's) Standard Review Plan Update and Development Program (SRP-UDP).

\section{CITED STANDARD:}

ASTM D2854-1970, "Standard Method of Test for Apparent Density of Activated Carbon"

\section{LATEST STANDARD:}

ASTM D2854-1989 (R1993), "Standard Test Method for Apparent Density of Activated Carbon"

\section{CONTENTS}

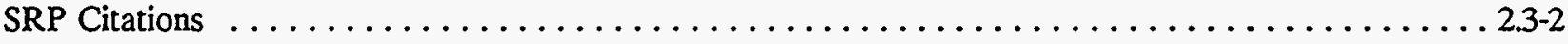

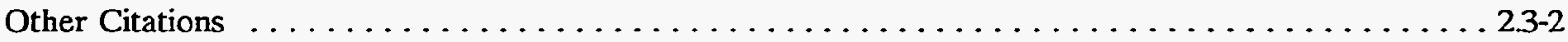

Regulatory Guide $1.140 \ldots \ldots \ldots \ldots \ldots \ldots \ldots \ldots \ldots \ldots \ldots \ldots \ldots \ldots \ldots \ldots \ldots \ldots \ldots \ldots \ldots \ldots \ldots .2$

II. CITED VS. LATEST STANDARD DIFFERENCES $\ldots \ldots \ldots \ldots \ldots \ldots \ldots \ldots \ldots \ldots \ldots \ldots \ldots \ldots \ldots \ldots . .2$

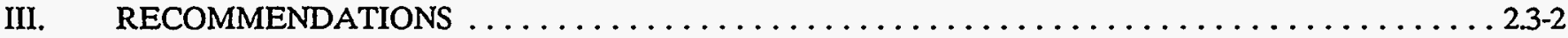

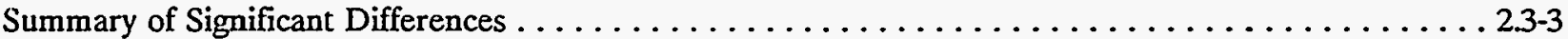

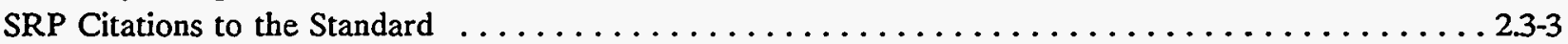

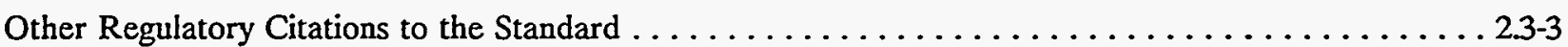




\section{REGULATORY CITATIONS}

This part of the comparison identifies specific citations to ASTM D2854 in the SRP and associated Regulatory Guides and 10 CFR sections. Recommendations on the disposition of these citations based on the results of this standard comparison are presented in Part III, Recommendations.

\section{SRP Citations}

None

\section{Other Citations}

\section{Regulatory Guide 1.140}

Revision/Title: Rev. 1, October 1979, "Design, Testing, and Maintenance Criteria for Normal Ventilation Exhaust System Air Filtration and Adsorption Units of Light-Water-Cooled Nuclear Power Plants"

Location: Regulatory Guide 1.140 cites ASTM D2854-1970 in Table 1, Item 6 and as Reference 11 in the Reference subsection.

Context: ASTM D2854 is cited for an acceptable test method for the apparent density of activated carbon. Regulatory Guide 1.140, relevant to this comparison, is cited as Acceptance Criteria in SRP Sections 11.1, 11.3 and 14.2.

\section{CITED VS. LATEST STANDARD DIFFERENCES}

This part of the comparison presents those changes from the cited version (1970) to the latest version (1989 (R 1993)) identified for ASTM D2854. The cited version of the standard was compared with the latest version, and no significant differences were found.

\section{RECOMMENDATIONS}

This part of the comparison summarizes significant differences (identified in Part II) between the cited and latest versions of the standard and addresses their effects on the citing documents. Those changes in the standard that added detail to existing requirements are not included in the summary of significant differences. The regulatory citations to ASTM D2854 (identified in Part I) are evaluated based on the significant differences between the cited and latest versions of this standard. Citations in the SRP are evaluated first, followed by citations in associated Regulatory Guides and 10 CFR sections. Recommendations concerning the updating of these citations as they relate to the SRP-UDP are also included in this part of the comparison. 


\section{Summary of Significant Differences}

No significant changes were identified. Even though there do not appear to be significant differences between the 1970 version and the 1989 (R1993) version of ASTM D2854, the latest version provides additional detail and appears to reflect current industry practice. It appears that Regulatory Guide 1.140 would be enhanced by citing the latest version (1989(R93)) of ASTM D2854.

\section{SRP Citations to the Standard}

None

Other Regulatory Citations to the Standard

Regulatory Guide 1.140, "Design, Testing, and Maintenance Criteria for Normal Ventilation Exhaust System Air Filtration and Adsorption Units of Light-Water-Cooled Nuclear Power Plants" (October 1979)

Recommendations for updating specific references in Regulatory Guide 1.140 are as follows:

Regulatory Guide

1.140 Paragraph

Table 1 and

Reference 11

\section{$\underline{\text { Recommendation }}$}

Even though there do not appear to be significant differences between the 1970 version and the 1989 (R93) version of ASTM D2854, the 1989 (R93) version provides additional detail and appears to reflect current industry practice. It appears that Regulatory Guide 1.140 would be enhanced by citing the current [1989 (R93)] version of ASTM D2854 that is maintained by ASTM. Pending revision of Regulatory Guide 1.140 to endorse ASTM D2854-1989 (R93), it is recommended that citations of Regulatory Guide 1.140 in SRP Sections 11.1, 11.3, and 14.2 be revised to indicate that the use of ASTM D2854-1989 (R93) is acceptable in meeting the relevant positions of the Regulatory Guide. 


\subsection{ASTM Standard D2862 Comparison}

This section presents a comparison of the version of ASTM D2862 cited in the Standard Review Plan (SRP) and associated Regulatory Guides and Code of Federal Regulation (CFR) sections with the latest version of the standard, in support of the Nuclear Regulatory Commission's (NRC's) Standard Review Plan Update and Development Program (SRP-UDP).

\section{CITED STANDARD:}

ASTM D2862-1970, "Standard Method of Test for Particle Size Distribution of Granular Activated Carbon"

\section{LATEST STANDARD:}

ASTM D2862-1992, "Standard Test Method for Particle Size Distribution of Granular Activated Carbon"

\section{CONTENTS}

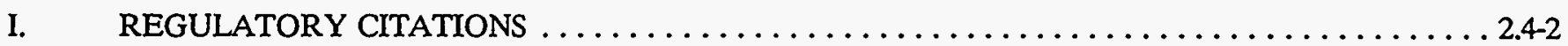

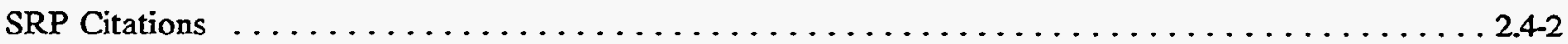

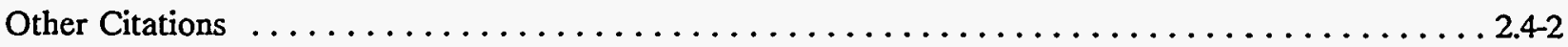

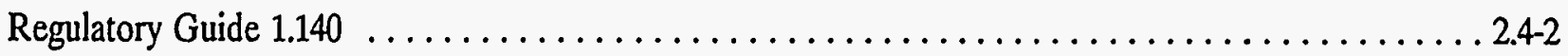

II. CITED VS. LATEST STANDARD DIFFERENCES $\ldots \ldots \ldots \ldots \ldots \ldots \ldots \ldots \ldots \ldots \ldots \ldots \ldots \ldots \ldots \ldots \ldots .2 .2$

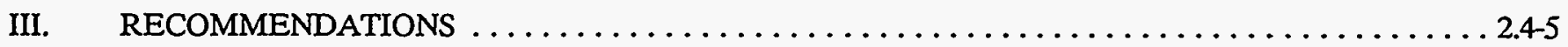

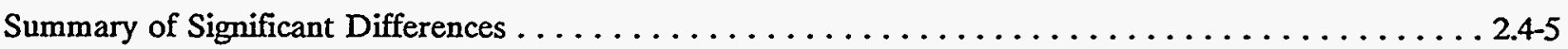

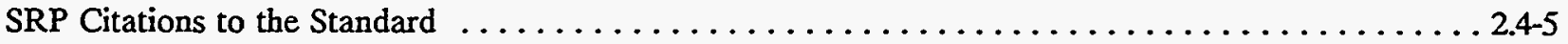

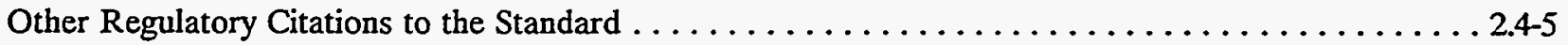




\section{REGULATORY CITATIONS}

This part of the comparison identifies specific citations to ASTM D2862 in the SRP and associated Regulatory Guides and 10 CFR sections. Recommendations on the disposition of these citations based on the results of this standard comparison are presented in Part III, Recommendations.

\section{SRP Citations}

None

\section{Other Citations}

\section{Regulatory Guide $\mathbf{1 . 1 4 0}$}

Revision/Title: October 1979, "Design, Testing, and Maintenance Criteria for Normal Ventilation Exhaust System Air Filtration and Adsorption Units of Light-Water-Cooled Nuclear Power Plants."

Location: Regulatory Guide 1.140 cites ASTM D2862-1970 in subsection C, "Regulatory Position."

Context: ASTM D2862 is endorsed by Regulatory Guide 1.140 as an acceptable test method for testing the particle size distribution of activated carbon. Regulatory Guide 1.140 is cited in the Acceptance Criteria and Review Procedures in SRP Section 11.3, "Gaseous Waste Management Systems," for the design, testing and maintenance of normal ventilation exhaust systems. Acceptance Criterion II.B.5 and Review Procedures III.5 deal specifically with design, testing, and maintenance criteria for charcoal adsorbers in filtration systems.

\section{CITED VS. LATEST STANDARD DIFFERENCES}

This part of the comparison presents those changes from the cited version (1970) to the latest version (1992) identified for ASTM D2862. Many of these changes involve formatting, editorial and grammatical differences. Others involve clarification (e.g., the addition of a figure or illustration) and have no effect on requirements. Those differences between the cited and latest versions of ASTM D2862 which are judged to be significant and warranted further investigation relative to the technical and regulatory effects of their citation in regulatory documents are tabulated and discussed on the following pages. 
To facilitate review and consideration of their effects on ASTM D2862 citations in regulatory documents, significant differences between the cited and latest versions are classified into the following change types:

1. new or changed requirements affecting established NRC positions and requirements,

2. new or changed requirements not addressed by established NRC positions and requirements,

3. new or changed requirements allowing more flexibility,

4. deleted or relaxed requirements, and

5. new or changed requirements adding detail to established NRC regulatory positions.

Further consideration of the effects of the changes presented in this section on the SRP and associated Regulatory Guides and CFR sections that cite ASTM D2862 is provided in the Part III, Recommendations, of this section. Those differences classified as change types 1-4 are summarized in Part III. 


\section{STRAIGHTFORWARD}

COMPARISONS

Section 2

\begin{tabular}{||c|l|c|c||}
\hline \multicolumn{3}{|c|}{ CITED VS. LATEST STANDARD DIFFERENCES: ASTM D2862 } \\
\hline $\begin{array}{c}\text { Section } \\
\text { cited \& } \\
\text { [latest] }\end{array}$ & \multicolumn{1}{|c||}{$\begin{array}{c}\text { Significant Changes } \\
\text { cited \& [latest] }\end{array}$} & $\begin{array}{l}\text { Type of } \\
\text { Change }\end{array}$ & \multicolumn{1}{c||}{ Discussion } \\
\hline $\begin{array}{l}\text { None } \\
{[6.1]}\end{array}$ & $\begin{array}{l}\text { Section 6 references Practice E 300 for collecting } \\
\text { and preparing the granular activated carbon } \\
\text { samples. }\end{array}$ & 1 & $\begin{array}{l}\text { The addition of ASTM E300 "Practice for Sampling } \\
\text { Industrial Chemicals," for collecting and preparing } \\
\text { granular activated carbon samples is new material } \\
\text { added to the 1992 version. }\end{array}$ \\
\hline
\end{tabular}

$\stackrel{N}{f}$ 


\section{RECOMMENDATIONS}

This part of the comparison summarizes significant differences (identified in Part II) between the cited and latest versions of the standard and addresses their regulatory effects on the citing documents. Those changes in the standard that added detail to existing requirements are not included in the summary of significant differences. The regulatory citations to ASTM D2862 (identified in Part I) are evaluated based on the significant differences between the cited and latest versions of this standard. Citations in the SRP are evaluated first, followed by citations in associated Regulatory Guides and $10 \mathrm{CFR}$ sections. Recommendations concerning the updating of these citations as they relate to the SRP-UDP are also included in this part of the comparison.

\section{Summary of Significant Differences}

The only significant change identified is a new reference to ASTM E300 "Practice for Sampling Industrial Chemicals," for collecting and preparing granular activated carbon samples. This change represents advances in the sampling technology and should enhance the application of this standard.

\section{SRP Citations to the Standard}

None

\section{Other Regulatory Citations to the Standard}

Regulatory Guide 1.140, Rev. 1, "Design, Testing, and Maintenance Criteria for Normal Ventilation Exhaust System Air Filtration and Adsorption Units of Light-Water-Cooled Nuclear Power Plants" (October 1979)

Regulatory Guide $\underline{1.140 \text { Paragraph }}$

C.3.g.

\section{$\underline{\text { Recommendation }}$}

Consider updating the citation of ASTM D2862 from the 1970 to the 1992 version. The paragraph states that each original or replacement batch of impregnated activated carbon used in the adsorber section should meet the qualification and batch test results summarized in Table 1 of this guide. In Table 1, it states that the acceptable test method for determining that the acceptable particle size distribution for new activated carbon is provided in ASTM D2862-70. 
Even though there appears to be one significant difference between the 1970 version and the 1992 version of ASTM D2862, the difference updates the requirements for sample selection and enhances the applicability of the standard. The nonsignificant changes in the 1992 version provide additional detail and appear to reflect the latest industry practice. It appears that Regulatory Guide 1.140 would be enhanced by citing the latest (1992) version of ASTM D2862 that is maintained by ASTM. Pending revision of Regulatory Guide 1.140 to endorse ASTM D28621992, it is recommended that citations of Regulatory Guide 1.140 in SRP Section 11.3 be revised to indicate that the use of ASTM D2862-1992 is acceptable in meeting the relevant positions of the Regulatory Guide. 


\subsection{ASTM Standard E23 Comparison}

This section presents the comparison for ASTM E23 for the Nuclear Regulatory Commission's (NRC's) Standard Review Plan Update and Development Program (SRP-UDP).

\section{CITED STANDARD:}

ASTM E23 (version not specified), "Standard Methods for Notched Bar Impact Testing of Metallic Materials" The 1981 version of ASTM E23 was in effect in July 1981 when SRP Section 5.2.3 was issued, and is used for this comparison.

\section{LATEST STANDARD:}

ASTM E23-1993a, "Standard Test Methods for Notched Bar Impact Testing of Metallic Materials"

\section{CONTENTS}

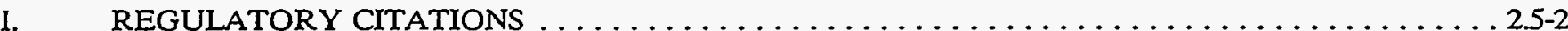

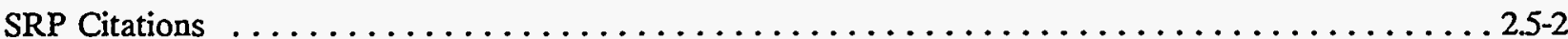

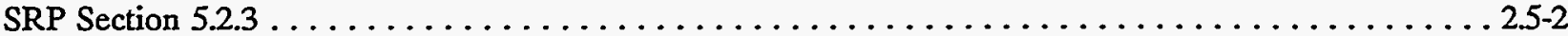

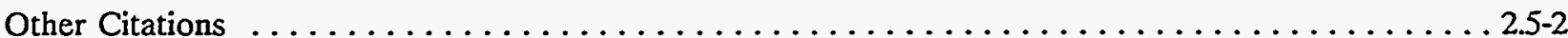

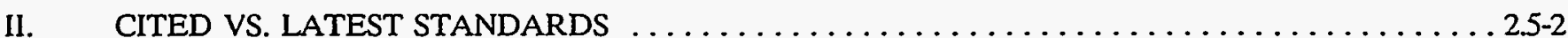

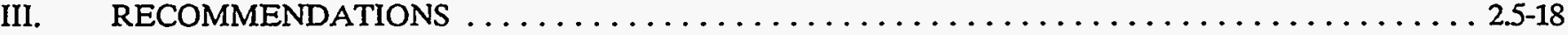

Summary of Significant Differences . . . . . . . . . . .

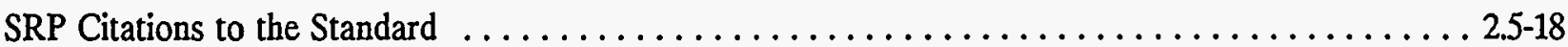

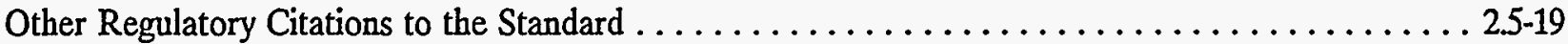




\section{REGULATORY CITATIONS}

This part of the comparison identifies specific citations to ASTM E23 in the SRP and associated Regulatory Guides and 10 CFR sections. Recommendations on the disposition of these citations based on the results of this standard comparison are presented in Part III, Recommendations.

\section{SRP Citations}

\section{SRP Section 5.2 .3}

Revision/Title: Section 5.2.3, Rev. 2, July 1981, "Reactor Coolant Pressure Boundary Materials"

Location: SRP 5.2.3 lists ASTM E23 as Reference 6 in subsection VI, "References."

Context: ASTM E23 is included in the list of references.

\section{Other Citations}

None

\section{CITED VS. LATEST STANDARDS}

This part of the comparison presents those changes from the cited version (1981) to the latest version (1993a) identified for ASTM E23. Many of these changes involve formatting, editorial and grammatical differences. Others involve clarification (e.g., the addition of a figure or illustration) and have no effect on requirements. Those differences between the cited and latest versions of ASTM E23 which are judged to be significant and warranted further investigation relative to the technical and regulatory effects of their citation in regulatory documents are tabulated and discussed on the following pages.

To facilitate review and consideration of their effects on ASTM E23 citations in regulatory documents, significant differences between the cited and latest versions are classified into the following change types:

1. new or changed requirements affecting established NRC positions and requirements,

2. new or changed requirements not addressed by established NRC positions and requirements,

3. new or changed requirements allowing more flexibility,

4. deleted or relaxed requirements, and

5. new or changed requirements adding detail to established NRC regulatory positions.

Further consideration of the effects of the changes presented in this section on the SRP and associated Regulatory Guides and CFR sections that cite ASTM E23 is provided in the Part III, Recommendations, of this section. Those differences classified as change types 1-4 are summarized in Part III. 


\begin{tabular}{|c|c|c|c|}
\hline \multicolumn{4}{|c|}{ CITED VS. LATEST STANDARD DIFFERENCES: ASTM E23 } \\
\hline $\begin{array}{l}\text { Section } \\
\text { cited \& } \\
\text { [latest] }\end{array}$ & $\begin{array}{c}\text { Significant Changes } \\
\text { cited \& [latest] }\end{array}$ & $\begin{array}{l}\text { Type of } \\
\text { Change }\end{array}$ & $\begin{array}{c}\cdot \\
\text { Discussion }\end{array}$ \\
\hline $\begin{array}{c}4.2 \\
{[5.2]}\end{array}$ & $\begin{array}{l}\text { These are comparable sections, with a numeration } \\
\text { shift. } \\
\text { The content of the sections is identical, except that } \\
\text { the } 1981 \text { version of the standard states: } \\
\text { "Pendulums used on Charpy machines are of two } \\
\text { basic designs;" whereas, the } 1993 \text { version states that } \\
\text { "Pendulums used on Charpy machines are of three } \\
\text { basic designs" and includes mention of a compound } \\
\text { pendulum (in addition to C-type and U-type } \\
\text { pendulums). (See also, } 1993 \text { Figure } 1 \text { versus } 1981 \\
\text { Figure 1.) }\end{array}$ & 3 & $\begin{array}{l}\text { The } 1993 \text { version describes three types of Charpy } \\
\text { machine pendulums (C-type, U-type and compound), } \\
\text { versus two types of such pendulums (C-type and U- } \\
\text { type)in the } 1981 \text { version. Neither standard appears } \\
\text { to base the testing requirements on a particular type } \\
\text { of pendulum. However, the } 1993 \text { version allows the } \\
\text { use of apparatus not covered in the } 1981 \text { version. }\end{array}$ \\
\hline
\end{tabular}




\begin{tabular}{|c|c|c|c|}
\hline \multicolumn{3}{|c|}{$\begin{array}{l}\text { STRAIGHTFORWARD } \\
\text { COMPARISONS } \\
\end{array}$} & \multirow[b]{2}{*}{ ENCES: ASTM E23 } \\
\hline \multicolumn{3}{|c|}{ CITED VS. LATEST STANDARD DIFFERENCES: ASTM E23 } & \\
\hline $\begin{array}{l}\text { Section } \\
\text { cited \& } \\
\text { [latest] }\end{array}$ & $\begin{array}{c}\text { Significant Changes } \\
\text { cited \& [latest] }\end{array}$ & $\begin{array}{l}\text { Type of } \\
\text { Change } \\
\end{array}$ & Discussion \\
\hline $\begin{array}{c}4.3 .4 \\
\text { [None] }\end{array}$ & $\begin{array}{l}\text { The } 1981 \text { version of the standard requires that } \\
\text { specimen supports be square with anvil faces within } \\
2.5: 1000 \text { and requires that specimen supports be } \\
\text { coplanar within } 0.125 \mathrm{~mm}(0.005 \text { in.) and parallel } \\
\text { within } 2: 1000 \text {. Such requirements do not appear in } \\
\text { the text of the } 1993 \text { version, but similar information } \\
\text { is provided in Figure } 2 \text { of both versions. }\end{array}$ & 4 & $\begin{array}{l}\text { The section text addressing specifications relative to } \\
\text { Charpy apparatus specimen supports has been } \\
\text { deleted in the } 1993 \text { version. However, the } \\
\text { requirements and tolerances for the supports arc } \\
\text { illustrated in Figure } 2 \text { of both versions. Figure two } \\
\text { is the same in both versions with the exception of } \\
\text { the deletion of the "Notes" and editorial differences. } \\
\text { The "Notes" provided in the } 1981 \text { version contain } \\
\text { specific tolerances. The figure in the } 1993 \text { version } \\
\text { contains a single statement providing tolerances. } \\
\text { There are minor differences between the tolerances } \\
\text { provided. Note } 3 \text { of the } 1981 \text { version provides } \\
\text { surface finish requirements. However it is not clear } \\
\text { whether these requirements apply to the specimen or } \\
\text { the apparatus. The same finish requirements are } \\
\text { contained in Figure } 4 \text { of the } 1993 \text { version for the test } \\
\text { specimen. There are differences between the two } \\
\text { versions of the standard with regard to the allowable } \\
\text { tolerances of the impact testing apparatus (although } \\
\text { they appear to be minor in nature) and the } \\
\text { applicability of the surface finish requirements in the } \\
\text { 1981 version cannot be definitively determined. }\end{array}$ \\
\hline
\end{tabular}




\begin{tabular}{|c|c|c|c|}
\hline \multicolumn{4}{|c|}{ CITED VS. LATEST STANDARD DIFFERENCES: ASTM E23 } \\
\hline $\begin{array}{l}\text { Section } \\
\text { cited \& } \\
\text { [latest] }\end{array}$ & $\frac{\text { Significant Changes }}{\text { cited \& [latest] }}$ & $\begin{array}{l}\text { Type of } \\
\text { Change }\end{array}$ & Discussion \\
\hline $\begin{array}{c}5.2 .3 \\
{[6.2 .3]}\end{array}$ & $\begin{array}{l}\text { These are comparable sections, with a numeration } \\
\text { shift. } \\
\text { The content of the sections is identical, except that } \\
\text { the } 1981 \text { version of the standard states: } \\
\text { "Determine the initial potential energy using the } \\
\text { following procedure when the center of strike of } \\
\text { the pendulum is coincident with the line from the } \\
\text { center of rotation through the center of percussion. } \\
\text { If the center of strike is more than } 2.5 \text { mm ( } 0.1 \text { in.) } \\
\text { from this line, ... ;" whereas, the } 1993 \text { version } \\
\text { states: "Determine the initial potential energy } \\
\text { using the following procedure when the center of } \\
\text { strike of the pendulum is coincident with a radial } \\
\text { line from the center line of the pendulum bearings } \\
\text { (herein called the axis of rotation) to the center of } \\
\text { gravity. (See Appendix X2.) If the center of strike } \\
\text { is more than } 1.0 \text { mm (0.04 in.) from this line, ..." } \\
\text { Also, the } 1981 \text { version refers to Sections } 5.2 .3 .2 \text {, } \\
5.2 .3 .3,5.2 .6 .1 \text { and } 5.2 .7 ; \text { whereas, the } 1993 \text { version } \\
\text { refers to Sections } 6.2 .3 .2,6.2 .3 .3,6.2 .6 .1 \text { and } 6.2 .7 .\end{array}$ & 1 & $\begin{array}{l}\text { The inclusion of greater specificity relative to the } \\
\text { determination of pendulum potential energy in the } \\
1993 \text { version is editorial with the exception of the } \\
\text { allowable tolerances. The } 1993 \text { version allows only a } \\
1 \mathrm{~mm} \text { deviation from center as compared to a } 2.5 \\
\text { mm tolerance in the } 1981 \text { version. This tolerance is } \\
\text { more restrictive than previously required. }\end{array}$ \\
\hline
\end{tabular}




\begin{tabular}{|c|c|c|c|}
\hline \multicolumn{4}{|c|}{$\begin{array}{l}\text { STRAIGHTFORWARD } \\
\text { COMPARISONS }\end{array}$} \\
\hline \multicolumn{4}{|c|}{ CITED VS. LATEST STANDARD DIFFERENCES: ASTM E23 } \\
\hline $\begin{array}{l}\text { Section } \\
\text { cited \& } \\
\text { [latest] }\end{array}$ & $\begin{array}{c}\text { Significant Changes } \\
\text { cited \& [latest] }\end{array}$ & $\begin{array}{l}\text { Type of } \\
\text { Change }\end{array}$ & Discussion \\
\hline $\begin{array}{c}5.2 .3 .4 \\
{[6.2 .3 .4]}\end{array}$ & $\begin{array}{l}\text { These are comparable sections, with a numeration } \\
\text { shift. } \\
\text { The content of the sections is identical, except that } \\
\text { the } 1981 \text { version uses the term "measure" (three } \\
\text { places) and refers to Section } 4.1 .7 \text {; whereas, the } \\
1993 \text { version uses the term "determine" (three } \\
\text { places), refers to Section } 5.1 .7 \text {, and includes the } \\
\text { statement: "The height may be determined by } \\
\text { direct measurement of the elevation of the center } \\
\text { of strike or by calculation from the change in angle } \\
\text { of the pendulum using the following formulas: } \\
\text { (See Fig. } 5 \text { ) } \\
\qquad S=L(1-\operatorname{Cos} \beta) \text { or } h_{1}=L(1-\operatorname{Cos} \alpha)^{\prime \prime \prime \prime}\end{array}$ & 1 & $\begin{array}{l}\text { The } 1993 \text { version includes formulas for calculation of } \\
\text { the height of the pendulum drop as an alternative to } \\
\text { direct measurement. The } 1981 \text { version does not } \\
\text { include the calculation alternative. The } 1993 \text { version } \\
\text { provides an alternative method to determining the } \\
\text { height of the pendulum, this could be construed as } \\
\text { an expansion in the standard with regard to } \\
\text { allowable methods, although the basic requirement } \\
\text { to determine the height is identical between the two } \\
\text { standards. }\end{array}$ \\
\hline
\end{tabular}




\begin{tabular}{|c|c|c|c|}
\hline \multicolumn{4}{|c|}{ CITED VS. LATEST STANDARD DIFFERENCES: ASTM E23 } \\
\hline $\begin{array}{l}\frac{\text { Section }}{\text { cited \& }} \\
\text { [latest] }\end{array}$ & $\begin{array}{c}\text { Significant Changes } \\
\text { cited \& [latest] } \\
\end{array}$ & $\begin{array}{l}\text { Type of } \\
\text { Change }\end{array}$ & Discussion \\
\hline $\begin{array}{c}5.2 .7 \\
{[6.2 .7]}\end{array}$ & $\begin{array}{l}\text { These are comparable sections, with a numeration } \\
\text { shift. } \\
\text { The content of the sections is identical, except that } \\
\text { the } 1981 \text { version uses the term "scale," refers to } \\
\text { Section } 5.2 .3 .3 \text {, uses the term "its weight," and } \\
\text { includes the statement: "Increase this value by } \\
\text { friction and windage losses in accordance with 5.2.6 } \\
\text { and subtract from the potential energy determined } \\
\text { in 5.2.3;" whereas, the } 1993 \text { version uses the term } \\
\text { "direct reading scale," refers to Section } 6.2 .3 .3 \text {, uses } \\
\text { the term "the supporting force," and includes the } \\
\text { statements: "Increase this value by the total } \\
\text { frictional and windage losses for a free swing (see } \\
6.2 .6 .1 \text { multiplied by the ratio of the angle of swing } \\
\text { during a test to twice the angle of fall. Subtract } \\
\text { the sum of the residual energy and proportional } \\
\text { frictional and windage loss from the potential } \\
\text { energy at the latched position. (See } 6.2 .3 \text {.)" }\end{array}$ & 1 & $\begin{array}{l}\text { The requirements regarding the indicating } \\
\text { mechanism accuracy are the same in both standards } \\
\text { with one exception. The } 1993 \text { version includes a } \\
\text { modified approach to determining the residual } \\
\text { energy value used to determine the accuracy of the } \\
\text { indicating mechanism. Specifically, the } 1993 \text { version } \\
\text { adjusts the frictional and windage losses by } \\
\text { multiplying by the ratio of the angle of swing to } \\
\text { twice the angle of fall. The } 1981 \text { version does not } \\
\text { appear to require similar adjustments. The changes } \\
\text { to the } 1993 \text { version involve modification of } \\
\text { calculational methods that impact the performance } \\
\text { of the test procedure. }\end{array}$ \\
\hline
\end{tabular}




\begin{tabular}{|c|c|c|c|}
\hline \multicolumn{4}{|c|}{ CITED VS. LATEST STANDARD DIFFERENCES: ASTM E23 } \\
\hline $\begin{array}{l}\text { Section } \\
\text { cited \& } \\
\text { [latest] }\end{array}$ & $\frac{\text { Significant Changes }}{\text { cited \& [latest] }}$ & $\begin{array}{l}\text { Type of } \\
\text { Change }\end{array}$ & Discussion \\
\hline $\begin{array}{l}\text { None } \\
\text { [11.2] }\end{array}$ & $\begin{array}{l}\text { The } 1993 \text { version of the standard requires that the } \\
\text { verified-range of a Charpy impact machine be } \\
\text { described by a lower value and a higher value; } \\
\text { requires that values of impact energy outside the } \\
\text { verified range be reported as approximate; and } \\
\text { includes specifications relative to determining the } \\
\text { verified range. Such provisions do not appear in } \\
\text { the } 1981 \text { version. }\end{array}$ & 1 & $\begin{array}{l}\text { The } 1993 \text { version includes provisions for determining } \\
\text { the verified range of a Charpy machine. Methods, } \\
\text { specifications, and criteria are provided for } \\
\text { determining higher and lower values that establish } \\
\text { the verified range. There are no similar provisions } \\
\text { in the } 1981 \text { standard. These changes constitute new } \\
\text { requirements for verification of the Charpy impact } \\
\text { machine. }\end{array}$ \\
\hline $\begin{array}{c}10.2 \\
{[11.3]}\end{array}$ & $\begin{array}{l}\text { These are comparable sections, with a numeration } \\
\text { shift. } \\
\text { The content of the sections is identical, except that } \\
\text { the } 1981 \text { version of the standard states: "Charpy } \\
\text { machines shall, however, be verified immediately } \\
\text { after replacing parts, making repairs ... ;" whereas, } \\
\text { the } 1993 \text { version states: "Charpy machines shall } \\
\text { also be verified immediately after replacing parts } \\
\text { that may affect the measured energy, after making } \\
\text { repairs ... " }\end{array}$ & 1 & $\begin{array}{l}\text { The } 1993 \text { version modifies the requirements } \\
\text { regarding the frequency of verification of a Charpy } \\
\text { machine following repairs. The } 1993 \text { version } \\
\text { requires verification be performed following the } \\
\text { replacement of parts that may affect the measured } \\
\text { energy, whereas the } 1981 \text { version requires } \\
\text { verification following parts replacement. The } 1993 \\
\text { version appears to relax the } 1981 \text { requirements by } \\
\text { only requiring verification for certain replacements } \\
\text { as opposed to all replacements as indicated in the } \\
\text { 1981 version. Both versions ensure verification is } \\
\text { performed for those parts that may have an } \\
\text { influence on the machine measurements. However, } \\
\text { the change seems to relax the overall requirements. }\end{array}$ \\
\hline
\end{tabular}




\begin{tabular}{|c|c|c|c|}
\hline \multicolumn{4}{|c|}{ CITED VS. LATEST STANDARD DIFFERENCES: ASTM E23 } \\
\hline $\begin{array}{l}\text { Section } \\
\text { cited \& } \\
\text { [latest] }\end{array}$ & $\begin{array}{c}\text { Significant Changes } \\
\text { cited \& [latest] }\end{array}$ & $\begin{array}{l}\text { Type of } \\
\text { Change }\end{array}$ & Discussion \\
\hline $\begin{array}{l}\text { None } \\
{[11.3 .1]}\end{array}$ & $\begin{array}{l}\text { The } 1993 \text { version of the standard requires that the } \\
\text { accuracy of a Charpy machine be rechecked when } \\
\text { parts that may affect the measured energy are } \\
\text { removed and then reinstalled without modification. } \\
\text { Such a provision does not appear in the } 1981 \\
\text { version. }\end{array}$ & 1 & $\begin{array}{l}\text { The } 1993 \text { version includes provisions for rechecking } \\
\text { the accuracy of Charpy machines following the } \\
\text { removal and reinstallation (without modification) of } \\
\text { parts that may affect the measured energy. There } \\
\text { are no similar requirements in the } 1981 \text { version. } \\
\text { The change appears to expand the requirements for } \\
\text { verification of the Charpy apparatus. }\end{array}$ \\
\hline $\begin{array}{c}\text { None } \\
{[12.2 .1 .1]}\end{array}$ & $\begin{array}{l}\text { The } 1993 \text { version of the standard states that, when } \\
\text { a specimen bath is near its boiling point, } \\
\text { evaporative cooling can dramatically lower the } \\
\text { specimen temperature during the interval between } \\
\text { removal from the bath and fracture ( } \leq 5 \text { seconds); } \\
\text { cites supporting data; and requires that, under such } \\
\text { conditions, referenced data or calibration data from } \\
\text { thermocouples be used to confirm that the } \\
\text { specimen is within the stated tolerance from the } \\
\text { desired temperature when the striker fractures the } \\
\text { specimen. Such provisions do not appear in the } \\
1981 \text { version. } \\
\text {. }\end{array}$ & 1 & $\begin{array}{l}\text { The } 1993 \text { version includes precautions relative to } \\
\text { evaporative cooling of specimens between removal } \\
\text { from a temperature bath, and fracture on the } \\
\text { machine. The } 1993 \text { version also includes provisions } \\
\text { for confirming that the required temperature } \\
\text { tolerances have been met at the time the specimen is } \\
\text { broken. Paragraph } 11.2 .3 .1 \text { of the } 1981 \text { version } \\
\text { directs that the specimen should be moved from the } \\
\text { bath and the impact performed in less than } 5 \\
\text { seconds. It appears that the precautions in the } 1993 \\
\text { version provide the basis or rationale for this time } \\
\text { limit and should be considered clarifications. } \\
\text { However, the additional provisions in the } 1993 \\
\text { version for confirming the temperature tolerances } \\
\text { have been met have no counterpart in the } 1981 \\
\text { version. This change appears to be an expansion in } \\
\text { the requirements. }\end{array}$ \\
\hline
\end{tabular}




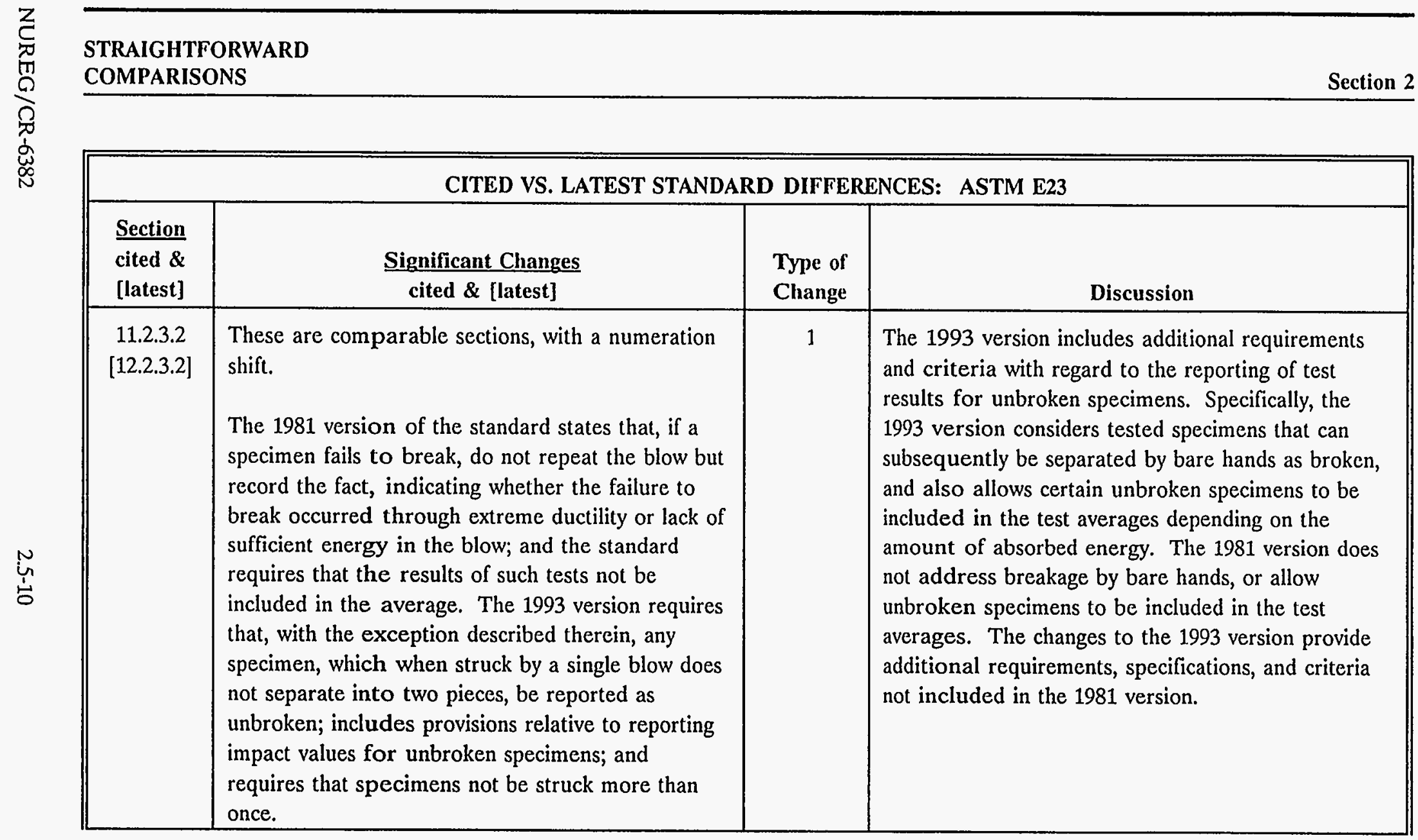




\begin{tabular}{|c|c|c|c|}
\hline \multicolumn{4}{|c|}{ CITED VS. LATEST STANDARD DIFFERENCES: ASTM E23 } \\
\hline $\begin{array}{l}\frac{\text { Section }}{\text { cited \& }} \\
\text { [latest] }\end{array}$ & $\frac{\text { Significant Changes }}{\text { cited \& [latest] }}$ & $\begin{array}{l}\text { Type of } \\
\text { Change }\end{array}$ & Discussion \\
\hline $\begin{array}{c}12 \\
{[13]}\end{array}$ & $\begin{array}{l}\text { These are comparable sections, with a numeration } \\
\text { shift. } \\
\text { The } 1981 \text { version of the standard states that, for } \\
\text { commercial acceptance testing, the type of } \\
\text { specimen used (and size if not the standard size) } \\
\text { and the temperature of the specimen are to be } \\
\text { reported; and the standard requires that, when } \\
\text { required, the energy absorbed, lateral expansion } \\
\text { and/or fracture appearance also be reported. The } \\
1993 \text { version states that, for commercial acceptance } \\
\text { testing, the specimen type (and size if not the full } \\
\text { size specimen), test temperature of the specimen, } \\
\text { and the energy absorbed are to be reported; and } \\
\text { the standard requires that, for other than } \\
\text { commercial acceptance testing, when required, } \\
\text { lateral expansion, fracture appearance, specimen } \\
\text { orientation, specimen location, original specimen } \\
\text { width and original specimen depth also be } \\
\text { reported. }\end{array}$ & 1 & $\begin{array}{l}\text { The reporting requirements for commercial } \\
\text { acceptance testing are essentially identical between } \\
\text { the two standards with the exception that the } 1993 \\
\text { version also requires absorbed energy to be included. } \\
\text { The } 1993 \text { version also expands the list of test data } \\
\text { that may be reported when required or specified. } \\
\text { The changes expand the reporting requirements. } \\
\text { However, this significance is limited in that the } \\
\text { reporting requirements have no impact on the data } \\
\text { acquisition, only on how the data is presented and } \\
\text { which data is presented. }\end{array}$ \\
\hline
\end{tabular}




\begin{tabular}{|c|c|c|c|}
\hline \multicolumn{4}{|c|}{$\begin{array}{l}\text { STRAIGHTFORWARD } \\
\text { COMPARISONS } \\
\end{array}$} \\
\hline \multicolumn{4}{|c|}{ CITED VS. LATEST STANDARD DIFFERENCES: ASTM E23 } \\
\hline $\begin{array}{l}\text { Section } \\
\text { cited \& } \\
\text { [latest] }\end{array}$ & $\begin{array}{c}\text { Significant Changes } \\
\text { cited \& [latest] }\end{array}$ & $\begin{array}{l}\text { Type of } \\
\text { Change }\end{array}$ & Discussion \\
\hline $\begin{array}{l}\text { Fig. } 1 \\
\text { [Fig. 1] }\end{array}$ & $\begin{array}{l}\text { These figures are identical, except that the } 1993 \\
\text { version of the standard includes an illustration for a } \\
\text { compound pendulum. (See also, } 1993 \text { Section } 5.2 \\
\text { versus } 1981 \text { Section } 4.2 \text {.) }\end{array}$ & 3 & $\begin{array}{l}\text { The } 1993 \text { version includes provisions for the use of } \\
\text { three types of Charpy machine pendulums (C-type, } \\
\text { U-type and compound), versus two types of such } \\
\text { pendulums (C-type and U-type) in the } 1981 \text { version. } \\
\text { Neither standard appears to base the testing } \\
\text { requirements on a particular type of pendulum. } \\
\text { However, the } 1993 \text { version allows the use of } \\
\text { apparatus not covered in the } 1981 \text { version. }\end{array}$ \\
\hline
\end{tabular}




\begin{tabular}{|c|c|c|c|}
\hline \multicolumn{4}{|c|}{ CITED VS. LATEST STANDARD DIFFERENCES: ASTM E23 } \\
\hline $\begin{array}{l}\text { Section } \\
\text { cited \& } \\
\text { [latest] }\end{array}$ & $\begin{array}{c}\text { Significant Changes } \\
\text { cited \& [latest] }\end{array}$ & $\begin{array}{l}\text { Type of } \\
\text { Change }\end{array}$ & Discussion \\
\hline $\begin{array}{l}\text { Fig. } 2 \\
\text { [Fig.2] }\end{array}$ & $\begin{array}{l}\text { These figures are identical, except that the } 1981 \\
\text { version of the standard uses the title "Charpy } \\
\text { (Simple Beam) Impact Test," includes the entry } \\
\text { "(2.5:1000)" in addition to the specification " } 90^{\circ} \pm \\
9^{\prime \prime \prime} \text { relative to the angle between the specimen and } \\
\text { the anvil, and includes three notes relative to } \\
\text { applicable tolerances; whereas, the } 1993 \text { version } \\
\text { uses the title "Charpy Striking Tup," shows the } \\
\text { angle between the specimen and the anvil as " } 90^{\circ} \pm \\
9,, " \text { does not include notes relative to applicable } \\
\text { tolerances, and includes an enlarged view of the tip } \\
\text { of the striking edge. }\end{array}$ & 4 & $\begin{array}{l}\text { The } 1993 \text { version deletes specifications relative to } \\
\text { Charpy apparatus specimen supports (from both the } \\
\text { subject figure and the referencing text section), notes } \\
\text { from the applicable figure, and adds an enlarged } \\
\text { view of the tip of the striking edge. The deleted } \\
\text { specifications and notes involve allowable tolerances } \\
\text { and surface finishes. The } 1993 \text { figure contains a } \\
\text { single statement regarding the allowable tolerances. } \\
\text { This statement was also included in the } 1981 \text { version } \\
\text { along with the Notes. It would appear that the } \\
\text { standard has deleted the notes in preference of this } \\
\text { single value. The differences in allowable tolerances } \\
\text { created by this approach appear to be minor and } \\
\text { conservative. With regard to the } 1981 \text { note } \\
\text { regarding surface finish, it cannot be readily } \\
\text { determined if this applies to the specimen, the } \\
\text { apparatus or both. Similar surface finishes are } \\
\text { required for specimens in the } 1993 \text { version. }\end{array}$ \\
\hline
\end{tabular}




\begin{tabular}{|c|c|c|c|}
\hline \multicolumn{3}{|c|}{$\begin{array}{l}\text { STRAIGHTFORWARD } \\
\text { COMPARISONS }\end{array}$} & Section \\
\hline \multicolumn{4}{|c|}{ CITED VS. LATEST STANDARD DIFFERENCES: ASTM E23 } \\
\hline $\begin{array}{l}\frac{\text { Section }}{\text { cited \& }} \\
\text { [latest] }\end{array}$ & $\begin{array}{c}\text { Significant Changes } \\
\text { cited \& [latest] }\end{array}$ & $\begin{array}{l}\text { Type of } \\
\text { Change }\end{array}$ & Discussion \\
\hline $\begin{array}{c}\text { Fig. } 4 \\
\text { [Fig. 4] }\end{array}$ & $\begin{array}{l}\text { These figures are essentially identical, but there are } \\
\text { differences in nomenclature and/or terminology, } \\
\text { the presentation of the contained information, and } \\
\text { permissible variations for cross-sections. }\end{array}$ & 4 & $\begin{array}{l}\text { The various differences in content/presentation } \\
\text { between the two figures are generally editorial in } \\
\text { nature. The only technical difference between the } \\
\text { two standards is with regard to permissible variations } \\
\text { in cross section dimensions as given in Note } 2 \text {. The } \\
1993 \text { version allows a greater variance than the } 1981 \\
\text { version. This change appears to be a relaxation in } \\
\text { previous specifications. }\end{array}$ \\
\hline $\begin{array}{l}\text { Fig. 6 } \\
\text { [Fig. 6] }\end{array}$ & $\begin{array}{l}\text { These figures are identical, except that the } 1993 \\
\text { version of the standard includes notch length to } \\
\text { edge specifications, does not include a note relative } \\
\text { to centering of the notch, uses the term "Notch } \\
\text { depth" versus "Dimensions to bottom of notch," has } \\
\text { a different permissible variation for cross-section } \\
\text { dimensions, and uses a different presentation } \\
\text { format for the permissible variations for notch } \\
\text { depth. }\end{array}$ & 1 & $\begin{array}{l}\text { The } 1993 \text { version includes notch length to edge } \\
\text { specifications not provided in the } 1981 \text { version, and } \\
\text { specifies different tolerances for cross-section } \\
\text { dimensions and notch depths for specimen types B } \\
\text { and C. These changes involve differences in } \\
\text { allowable tolerance specifications. }\end{array}$ \\
\hline $\begin{array}{c}\text { Fig. } 7 \\
\text { [Fig. 7] }\end{array}$ & $\begin{array}{l}\text { These figures are identical, except that the } 1993 \\
\text { version of the standard includes a notch length to } \\
\text { edge specification, uses the term "Notch depth" } \\
\text { versus "Dimensions to bottom of notch," and uses a } \\
\text { different presentation format for notch depth and } \\
\text { the associated permissible variation. }\end{array}$ & 1 & $\begin{array}{l}\text { The inclusion in the } 1993 \text { version of a notch length } \\
\text { to edge specification represents an additional } \\
\text { tolerance specification apparently not required in the } \\
1981 \text { version. This change constitutes an expansion } \\
\text { in requirements. }\end{array}$ \\
\hline
\end{tabular}




\begin{tabular}{|c|c|c|c|}
\hline \multicolumn{4}{|c|}{ CITED VS. LATEST STANDARD DIFFERENCES: ASTM E23 } \\
\hline $\begin{array}{l}\text { Section } \\
\text { cited \& } \\
\text { [latest] }\end{array}$ & $\begin{array}{c}\text { Significant Changes } \\
\text { cited \& [latest] }\end{array}$ & $\begin{array}{l}\text { Type of } \\
\text { Change } \\
\end{array}$ & Discussion \\
\hline $\begin{array}{l}\text { Fig. 11 } \\
\text { [Fig. 11] }\end{array}$ & $\begin{array}{l}\text { These figures are identical, except that the } 1993 \\
\text { version of the standard uses the term "Notch depth" } \\
\text { versus "Dimensions to bottom of notch," uses a } \\
\text { different presentation format for notch depth and } \\
\text { the associated permissible variation, includes as a } \\
\text { note permissible variations specifically applicable to } \\
\text { Type X specimens, and identifies the contents of a } \\
\text { note which also appears in the } 1981 \text { version as } \\
\text { being applicable "for both specimens." }\end{array}$ & 1 & $\begin{array}{l}\text { The } 1993 \text { version includes additional tolerances for } \\
\text { type X Izod specimens. Specifically the } 1993 \text { version } \\
\text { includes tolerances for "notch length to edge" and } \\
\text { "adjacent sides" dimensions. While the "notch length } \\
\text { to edge" tolerance appears to be new to the } 1993 \\
\text { version, the "adjacent sides" tolerance is included in } \\
\text { several other figures in the } 1981 \text { version that provide } \\
\text { specimen dimensions and tolerances. The "adjacent } \\
\text { side" tolerance given in the } 1993 \text { version is consistent } \\
\text { with the values given in the other figures from the } \\
1981 \text { version. However, the changes involve new } \\
\text { specifications from those in the } 1981 \text { version. }\end{array}$ \\
\hline $\begin{array}{l}\text { Fig. } 12 \\
\text { [Fig. 12] }\end{array}$ & $\begin{array}{l}\text { These figures are identical, except that the } 1993 \\
\text { version of the standard includes the note: "The flat } \\
\text { shall be parallel to the longitudinal centerline of } \\
\text { the specimen and shall be parallel to the bottom of } \\
\text { the notch within } 2: 1000, \text {, uses the term "Notch } \\
\text { depth" versus "Dimension to bottom of notch," uses } \\
\text { a different presentation format for notch depth and } \\
\text { the associated permissible variation, and includes a } \\
\text { permissible variation for notch length to } \\
\text { longitudinal centerline. }\end{array}$ & 1 & $\begin{array}{l}\text { The inclusion of a note relative to the specimen flat } \\
\text { and the inclusion of a permissible variation for notch } \\
\text { length to longitudinal centerline represent additional } \\
\text { tolerances for which there are no apparent } \\
\text { counterparts in the } 1981 \text { version. These new } \\
\text { allowable tolerances appear to constitute an } \\
\text { expansion in the requirements of the standard. }\end{array}$ \\
\hline
\end{tabular}




\begin{tabular}{|c|c|c|c|}
\hline 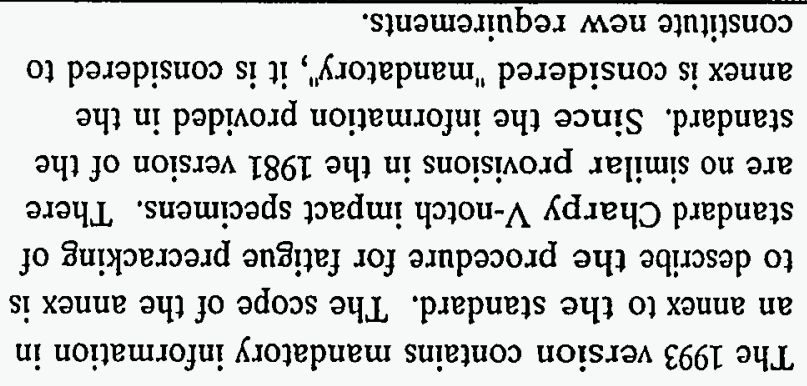 & I & 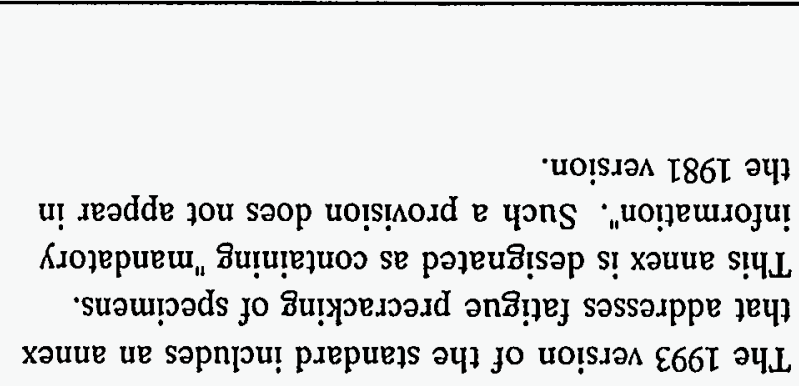 & $\begin{array}{c}{[\tau \forall} \\
\text { xauน }] \\
\text { วuoN }\end{array}$ \\
\hline 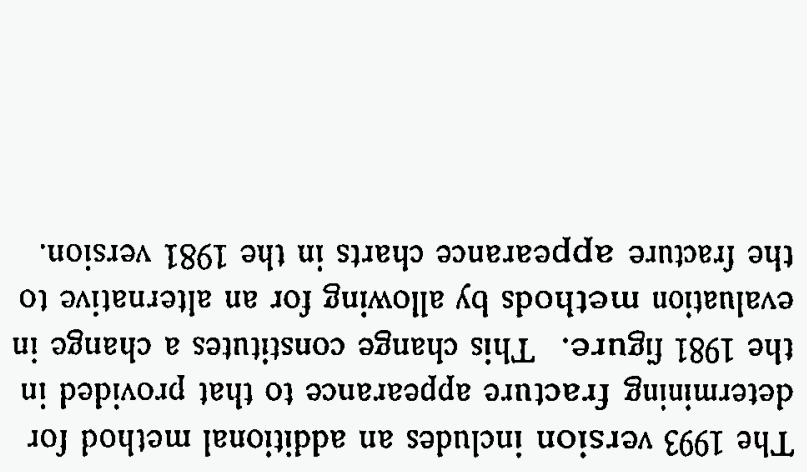 & $\varepsilon$ & 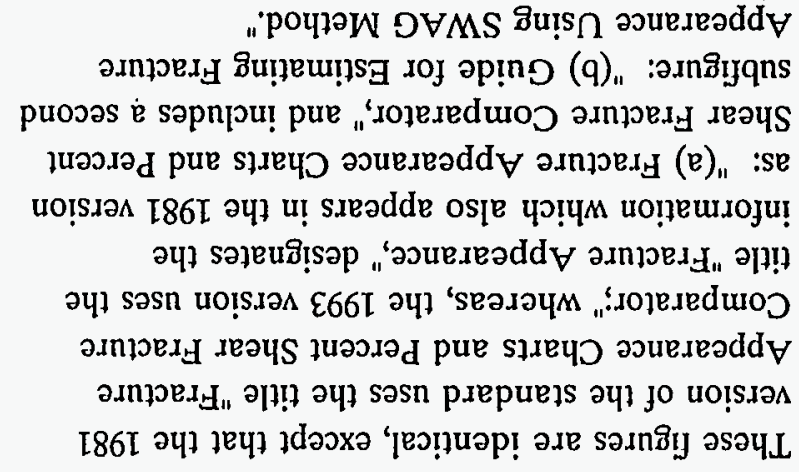 & $\begin{array}{c}\text { [SI } \cdot 8 !+4] \\
\text { SI } \cdot 8 ! d]\end{array}$ \\
\hline uo!ssnวs! $\propto$ & 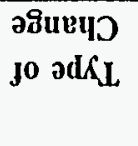 & 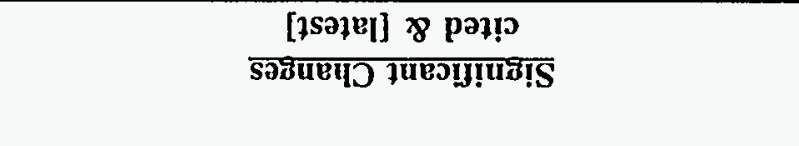 & 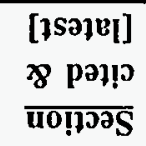 \\
\hline
\end{tabular}




\begin{tabular}{|c|c|c|c|}
\hline \multicolumn{4}{|c|}{ CITED VS. LATEST STANDARD DIFFERENCES: ASTM E23 } \\
\hline $\begin{array}{l}\frac{\text { Section }}{\text { cited \& }} \\
\text { [latest] }\end{array}$ & $\begin{array}{c}\text { Significant Changes } \\
\text { cited \& [latest] } \\
\end{array}$ & $\begin{array}{l}\text { Type of } \\
\text { Change }\end{array}$ & Discussion \\
\hline $\begin{array}{c}\text { XI.1.1 } \\
\text { [XI.1.1] }\end{array}$ & $\begin{array}{l}\text { The } 1981 \text { version of the standard states that Charpy } \\
\text { and Izod type tests bring out brittleness versus } \\
\text { ductility behavior by applying a single overload of } \\
\text { stress; that the energy values determined are } \\
\text { quantitative comparisons on a selected specimen } \\
\text { but cannot be converted into energy values for } \\
\text { design engineering calculations; and that the notch } \\
\text { behavior indicated cannot be generalized to sizes of } \\
\text { specimens and conditions other than those to which } \\
\text { an individual test applies. The } 1993 \text { version states } \\
\text { that Charpy V-notch impact tests have been used } \\
\text { extensively in mechanical testing of steel products, } \\
\text { in research and in procurement specifications; and } \\
\text { the standard states that, where correlations with } \\
\text { fracture mechanics parameters are available, it is } \\
\text { possible to specify CVN toughness values that } \\
\text { would ensure elastic-plastic or plastic behavior for } \\
\text { fracture of fatigue cracked specimens subjected to } \\
\text { minimum operating temperatures and maximum in } \\
\text { service rates of loading. }\end{array}$ & 3 & $\begin{array}{l}\text { While this portion of the standard is considered as } \\
\text { information only, the changes to the introductory } \\
\text { remarks on Charpy V-notch testing appear to allow } \\
\text { broader use of the impact test data. }\end{array}$ \\
\hline
\end{tabular}




\section{RECOMMENDATIONS}

This part of the comparison summarizes significant differences (identified in Part II) between the cited and latest versions of the standard and addresses their regulatory effects on the citing documents. Those changes in the standard that added detail to existing requirements are not included in the summary of significant differences. The regulatory citations to ASTM E23 (identified in Part I) are evaluated based on the significant differences between the cited and latest versions of this standard. Citations in the SRP are evaluated first, followed by citations in associated Regulatory Guides and $10 \mathrm{CFR}$ sections. Recommendations concerning the updating of these citations as they relate to the SRP-UDP are also included in this part of the comparison.

\section{Summary of Significant Differences}

Significant changes include changes to the requirements, specifications, methods, or other elements of the standard that may have a direct impact on implementation of the standard, and for that reason appears to be significant. These changes involve such issues as changes to tolerance specifications for test specimens and apparatus, revised procedures and requirements for verification of the Charpy apparatus, alternative or modified methods for determining pendulum height and residual energy, the addition of an annex containing mandatory information, and modifications to reporting requirements.

ASTM is cited only in the Reference subsection of SRP Section 5.2.3, and neither the standard, nor the reference to the standard appear in the body of the SRP Section. However, the SRP does make reference in several places to Charpy V-notch impact testing, including the Acceptance Criteria and Review Procedures, which indicates that the reference to ASTM E23 was included in the SRP as supporting information, although none of the specific requirements of the standard are discussed. Accordingly, subject to NRC analysis of the significant differences, consideration should be given to revising SRP Section 5.2.3 to reference ASTM E23-1993a since the type and nature of the changes to ASTM E23 do not appear to conflict with the regulatory requirements of the SRP.

\section{SRP Citations to the Standard}

\section{Section 5.2.3, "Reactor Coolant Pressure Boundary Materials" (July 1981)}

Subject to NRC review of the apparently significant changes, consider updating the reference to ASTM E23-1981 to ASTM E23-1993a as follows: 
SRP Section 5.2.3

Paragraph

$\underline{\text { Recommendation }}$

Reference 6

Replace the reference to ASTM E23 with ASTM E23-1993a, "Standard Test Methods for Notched Bar Impact Testing of Metallic Materials," Annual Book of ASTM Standards, American Society for Testing and Materials.

Other Regulatory Citations to the Standard

None 


\subsection{ASTM Standard E208 Comparison}

This section presents a comparison of the version of ASTM E208 cited in the Standard Review Plan (SRP) and associated Regulatory Guides and Code of Federal Regulation (CFR) sections with the latest version of the standard, in support of the Nuclear Regulatory Commission's (NRC's) Standard Review Plan Update and Development Program (SRP-UDP).

\section{CITED STANDARD:}

ASTM E208-1969, "Standard Method for Conducting Drop-Weight Test to Determine Nil-Ductility Transition Temperature of Ferritic Steels." The 1969 version is cited in SRP Section 5.4.1.1. The other SRP sections do not specify the version used. However, the 1969 version was in effect in July 1981 when the SRP sections were issued, and was used for this comparison.

\section{LATEST STANDARD:}

ASTM E208-1991, "Standard Test Method for Conducting Drop-Weight Test to Determine Nil-Ductility Transition Temperature of Ferritic Steels"

\section{CONTENTS}

I.

REGULATORY CITATIONS $\ldots \ldots \ldots \ldots \ldots \ldots \ldots \ldots \ldots \ldots \ldots \ldots \ldots \ldots \ldots \ldots .6 \ldots \ldots \ldots \ldots .2$

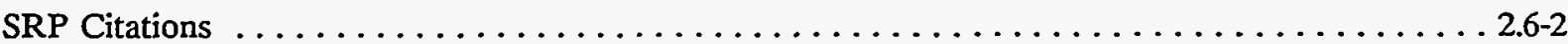

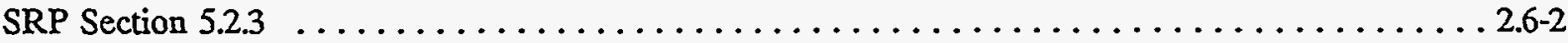

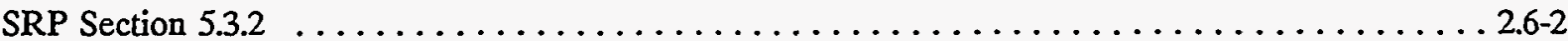

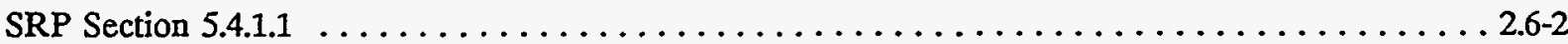

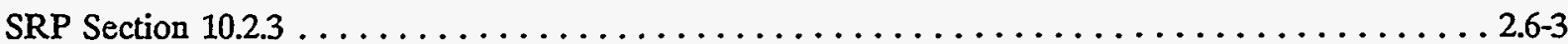

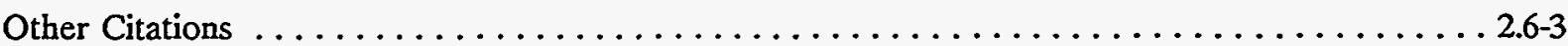

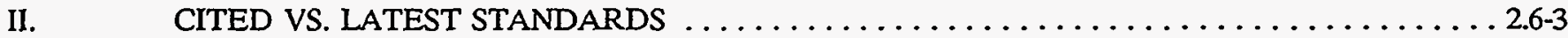

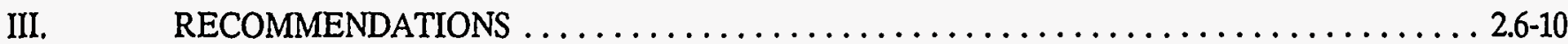

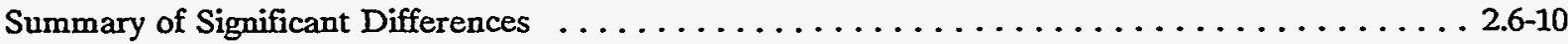

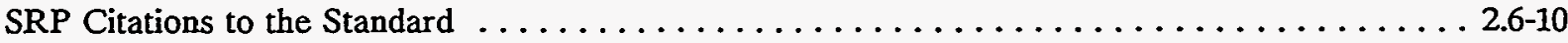

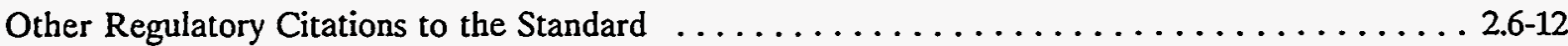




\section{REGULATORY CITATIONS}

This part of the comparison identifies specific citations to ASTM E208 in the SRP and associated Regulatory Guides and 10 CFR sections. Recommendations on the disposition of these citations based on the results of this standard comparison are presented in Part III, Recommendations.

\section{SRP Citations}

\section{SRP Section 5.2.3}

Revision/Title: Section 5.2.3, Rev. 2, July 1981, "Reactor Coolant Pressure Boundary Materials"

Location: SRP 5.2.3 lists ASTM E208 among its References.

Context: ASTM E208 is included in the list of references.

\section{SRP Section 5.3.2}

Revision/Title: Section 5.3.2, Rev. 1, July 1981, "Pressure-Temperature Limits"

Location: SRP 5.3.2, BTP CMEB 5-2, cites ASTM E208 in B. "Branch Technical Positions."

Context: ASTM E208 is cited by SRP 5.3.2 as an acceptable test to determine the NDT temperature.

\section{SRP Section 5.4.1.1}

Revision/Title: Section 5.4.1.1, Rev. 1, July 1981, "Pump Flywheel Integrity"

Location: SRP 5.4.1.1 cites ASTM E208-1969 in subsection II, "Acceptance Criteria" and also under "References."

Context: ASTM E208 is endorsed by SRP 5.4.1.1 as an acceptable test to determine the NDT temperature of the flywheel material. 


\section{SRP Section 10.2 .3}

Revision/Title: Section 10.2.3, Rev. 1, July 1981, "Turbine Disk Integrity"

Location: SRP 10.2.3 cites ASTM E208 in subsection II, "Acceptance Criteria" and also under "References."

Context: ASTM E208 is endorsed by SRP 10.2.3 as an acceptable test to determine the NDT temperature for low-pressure turbine disks.

\section{Other Citations}

None

\section{CITED VS. LATEST STANDARDS}

This part of the comparison presents those changes from the cited version (1969) to the latest version (1991) identified for ASTM E208. Many of these changes involve formatting, editorial and grammatical differences. Others involve clarification (e.g., the addition of a figure or illustration) and have no effect on requirements. Those differences between the cited and latest versions of ASTM E208 which are judged to be significant and warranted further investigation relative to the technical and regulatory effects of their citation in regulatory documents are tabulated and discussed on the following pages.

To facilitate review and consideration of their effects on ASTM E208 citations in regulatory documents, significant differences between the cited and latest versions are classified into the following change types:

1. new or changed requirements affecting established NRC positions and requirements,

2. new or changed requirements not addressed by established NRC positions and requirements,

3. new or changed requirements allowing more flexibility,

4. deleted or relaxed requirements, and

5. new or changed requirements adding detail to established NRC regulatory positions.

Further consideration of the effects of the changes presented in this section on the SRP and associated Regulatory Guides and CFR sections that cite ASTM E208 is provided in the Part III, Recommendations, of this section. Those differences classified as change types 1-4 are summarized in Part III. 


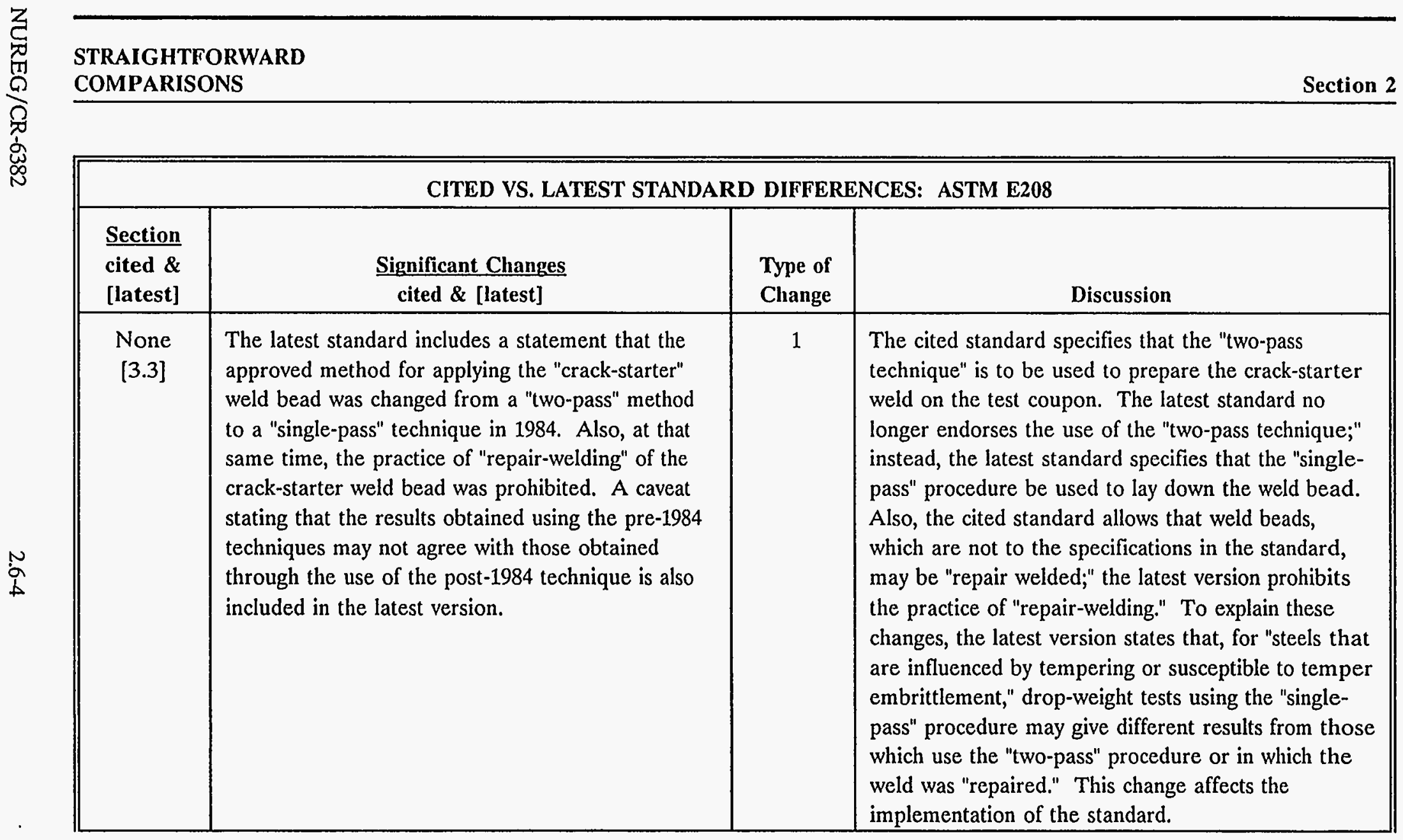




\begin{tabular}{|c|c|c|c|}
\hline \multicolumn{4}{|c|}{ CITED VS. LATEST STANDARD DIFFERENCES: ASTM E208 } \\
\hline $\begin{array}{l}\text { cited \& } \\
\text { [latest] }\end{array}$ & $\frac{\text { Significant Changes }}{\text { cited \& [latest] }}$ & $\begin{array}{l}\text { Type of } \\
\text { Change }\end{array}$ & Discussion \\
\hline $\begin{array}{c}7.4 .3 \\
{[7.4 .3]}\end{array}$ & $\begin{array}{l}\text { The last entry in the table has been changed. In } \\
\text { the cited standard, if } T \text { is the thickness of the cast } \\
\text { product, then the size of a "separately cast, } \\
\text { nonchilled, test coupon" is "T by } T \text { by } 6 \sqrt{T} \text { for } \\
\text { castings that are representative of cast bars." In } \\
\text { the latest version, the phrase "representative of cast } \\
\text { bars" has been changed to read "representative of } \\
\text { cast plates." }\end{array}$ & 4 & $\begin{array}{l}\text { The last entry in the right hand column of the table } \\
\text { in the cited version describes the dimensions of the } \\
\text { test coupon for "castings that are representative of } \\
\text { cast bars." The analogous entry in the latest version } \\
\text { describes coupon dimensions for "castings that are } \\
\text { representative of cast plates." Based on a } \\
\text { conversation with a member of the ASTM E208 } \\
\text { standards committee, this change is most likely an } \\
\text { editorial error, and was not intended by the } \\
\text { standards committee. As a result, the latest version } \\
\text { includes two different specifications for test coupons } \\
\text { for plate-like castings, but none for bar-like castings. } \\
\text { The } 1991 \text { version omits specifications for bar-like } \\
\text { castings. }\end{array}$ \\
\hline
\end{tabular}




\section{STRAIGHTFORWARD}

\begin{tabular}{|c|c|c|c|}
\hline \multicolumn{4}{|c|}{ CITED VS. LATEST STANDARD DIFFERENCES: ASTM E208 } \\
\hline $\begin{array}{l}\text { cited \& } \\
\text { [latest] }\end{array}$ & $\frac{\text { Significant Changes }}{\text { cited \& [latest] }}$ & $\begin{array}{l}\text { Type of } \\
\text { Change }\end{array}$ & Discussion \\
\hline $\begin{array}{c}7.7 \\
{[7.7]}\end{array}$ & $\begin{array}{l}\text { The phrase "in a single pass" has been added to the } \\
\text { end of the first sentence in the latest version. }\end{array}$ & 1 & $\begin{array}{l}\text { Both versions specify the dimensions and important } \\
\text { characteristics of the crack-starter weld bead. The } \\
\text { latest version of the standard also states that the } \\
\text { bead is to be deposited in a single pass. This is a } \\
\text { reflection of the change in the approved procedure } \\
\text { for placing the crack-starter weld. }\end{array}$ \\
\hline $\begin{array}{c}\text { Footnote } \\
3 \\
\text { [Footnote } \\
5]\end{array}$ & $\begin{array}{l}\text { The footnote in the cited version describes } \\
\text { electrodes that have been found to be suitable for } \\
\text { the production of the crack-starter weld; this } \\
\text { description includes the name and address of the } \\
\text { electrode manufacturer. The footnote in the latest } \\
\text { version indicates that the electrode described in the } \\
\text { cited version is no longer manufactured. New } \\
\text { sources of appropriate electrodes are listed, along } \\
\text { with the caveat that the subcommittee has not been } \\
\text { able to test these electrodes and potential users } \\
\text { must perform their own evaluations of the } \\
\text { acceptability of a given electrode type in } \\
\text { accordance with subsection } 7.10 \text { of this standard. }\end{array}$ & 3 & $\begin{array}{l}\text { These footnotes in the two versions of the standard } \\
\text { list weld electrodes that may be used with the } \\
\text { procedures in this standard. The names and } \\
\text { addresses of the manufacturers of these electrodes } \\
\text { are also included. The latest version indicates that } \\
\text { the electrodes listed in the cited version are no } \\
\text { longer being manufactured. The latest version lists } \\
\text { alternate electrodes, but includes the warning that } \\
\text { the electrodes in the new list have not been tested } \\
\text { by the standards committee. Both versions } \\
\text { recommend that the implementors of the standard } \\
\text { conduct their own tests on the suitability of the } \\
\text { electrodes to be used. Nevertheless, this change } \\
\text { affects information that is important to the } \\
\text { implementation of the standard; it also indicates that } \\
\text { the "satisfactory" electrodes per the cited version are } \\
\text { no longer available, but rather there are sources that } \\
\text { "produce appropriate electrodes." }\end{array}$ \\
\hline
\end{tabular}




\begin{tabular}{|c|c|c|c|}
\hline \multicolumn{4}{|c|}{ CITED VS. LATEST STANDARD DIFFERENCES: ASTM E208 } \\
\hline $\begin{array}{l}\text { Section } \\
\text { cited \& } \\
\text { [latest] }\end{array}$ & $\begin{array}{l}\text { Significant Changes } \\
\text { cited \& [latest] }\end{array}$ & $\begin{array}{l}\text { Type of } \\
\text { Change } \\
\end{array}$ & $\begin{array}{c}\cdot \\
\text { Discussion }\end{array}$ \\
\hline $\begin{array}{c}7.7 \\
{[7.7]}\end{array}$ & $\begin{array}{l}\text { The cited version states that points } A \text { and } D \text { (as } \\
\text { shown in figure } 7(a) \text { of the standard) are the weld } \\
\text { start locations and that the terminal point for each } \\
\text { half of the weld bead is the center point } C \text {. The } \\
\text { latest version states that the weld shall proceed } \\
\text { from point } A \text { to point } D \text {, or vice versa, without } \\
\text { interruption. The latest version also states that the } \\
\text { weld is to be a stringer bead, i.e. there is to be no } \\
\text { weaving or oscillation of the electrode transverse to } \\
\text { the direction of the weld. }\end{array}$ & 1 & $\begin{array}{l}\text { Both versions of the standard provide detail in the } \\
\text { procedure by which the crack-starter weld is to be } \\
\text { deposited. As a consequence of the fact that the } \\
\text { latest version has replaced the "two-pass" technique } \\
\text { with the "single-pass" technique, the procedures in } \\
\text { the two versions are vastly different. The latest } \\
\text { version also prohibits a weaving motion from being } \\
\text { used to lay down the weld bead. These changes } \\
\text { impose different requirements on the welding } \\
\text { procedures. }\end{array}$ \\
\hline $\begin{array}{c}7.7 \\
\text { [None] }\end{array}$ & $\begin{array}{l}\text { The cited version discusses that an oscillating or } \\
\text { weaving motion of the weld electrode is } \\
\text { unnecessary if electrodes of the type listed in the } \\
\text { footnote are used. The cited version also mentions } \\
\text { that the weld height at the center of the bead be } \\
\text { equal to the bead crown, and that "any discrepancy } \\
\text { observed after cleaning the weld can be corrected } \\
\text { by adding more metal to the crater-depression." } \\
\text { There is no corresponding discussion in the latest } \\
\text { version. }\end{array}$ & 1 & $\begin{array}{l}\text { The cited version states that an oscillating motion is } \\
\text { unnecessary when depositing the weld bead, but it } \\
\text { does not prohibit the practice as the latest version } \\
\text { does. The cited version also includes a } \\
\text { recommendation on the height of the weld bead, and } \\
\text { allows that more metal may be added to the crater } \\
\text { depression to correct any deficiencies. (Weld } \\
\text { repairing in such a manner is prohibited by the } \\
\text { latest version.) These differences affect welding } \\
\text { procedures. }\end{array}$ \\
\hline $\begin{array}{c}7.9 \\
{[\text { None] }}\end{array}$ & $\begin{array}{l}\text { The cited version includes a procedure by which } \\
\text { welds that are notched too deeply may be repaired. } \\
\text { Such information is not present in the latest } \\
\text { version. }\end{array}$ & 1 & $\begin{array}{l}\text { The cited version includes details of a repair } \\
\text { procedure for crack-starter welds that are notched } \\
\text { too deeply. No similar procedure is presented in the } \\
\text { latest version, consistent with its prohibition against } \\
\text { the use of "weld-repairing" techniques. }\end{array}$ \\
\hline
\end{tabular}




\begin{tabular}{|c|c|c|c|}
\hline \multicolumn{4}{|c|}{ CITED VS. LATEST STANDARD DIFFERENCES: ASTM E208 } \\
\hline $\begin{array}{l}\text { Section } \\
\text { cited \& } \\
\text { [latest] }\end{array}$ & $\begin{array}{c}\text { Significant Changes } \\
\text { cited \& [latest] }\end{array}$ & $\begin{array}{l}\text { Type of } \\
\text { Change }\end{array}$ & Discussion \\
\hline $\begin{array}{c}\text { None } \\
\text { [Note 1, } \\
\text { Note 2] }\end{array}$ & $\begin{array}{l}\text { Note } 1 \text { in the latest standard includes a procedure } \\
\text { which may be useful in determining if a tightly } \\
\text { closed crack extends across the tension surface. } \\
\text { Note } 2 \text { in the latest version clarifies the guidance } \\
\text { for determining if a specimen has been broken as a } \\
\text { result of the drop-weight test. This information is } \\
\text { not available in the cited standard. }\end{array}$ & 1 & $\begin{array}{l}\text { The latest version contains information and guidance } \\
\text { that is not found in the cited version. The latest } \\
\text { version includes a procedure for determining if a } \\
\text { tightly closed crack has actually propagated across } \\
\text { the tension surface of the specimen. Also, the latest } \\
\text { version includes guidance which states that if any } \\
\text { crack on the tension face extends to the edge of the } \\
\text { specimen, the specimen is considered broken, } \\
\text { regardless of whether or not the crack began at the } \\
\text { crack-starter. The addition of this information to } \\
\text { the latest version affects testing procedures. }\end{array}$ \\
\hline $\begin{array}{c}13.2 .3 \\
{[13.2 .3]}\end{array}$ & $\begin{array}{l}\text { In the cited version of the standard, the test is not } \\
\text { considered valid if "the weld-deposit notch is not } \\
\text { visibly broken after the test and the drop-weight } \\
\text { specimen is not deflected fully to contact the anvil } \\
\text { stop..." In the latest version, the word "either" has } \\
\text { been inserted at the beginning of the quoted text } \\
\text { and the word "and" replaced with "or." }\end{array}$ & 1 & $\begin{array}{l}\text { The criteria for determining if a particular test } \\
\text { performance is invalid are as follows: (1) the weld- } \\
\text { deposit notch is not visibly broken, and (2) the drop- } \\
\text { weight specimen has not been deflected to the anvil } \\
\text { stop. In the cited version, both of these criteria } \\
\text { must be met for the test to be considered invalid. In } \\
\text { the latest version, the presence of either of the } \\
\text { conditions is sufficient to invalidate the test. This } \\
\text { difference affects test evaluation criteria. }\end{array}$ \\
\hline
\end{tabular}




\begin{tabular}{|c|c|c|c|}
\hline \multicolumn{4}{|c|}{ CITED VS. LATEST STANDARD DIFFERENCES: ASTM E208 } \\
\hline $\begin{array}{l}\text { Section } \\
\text { cited \& } \\
\text { [latest] }\end{array}$ & $\frac{\text { Significant Changes }}{\text { cited \& [latest] }}$ & $\begin{array}{l}\text { Type of } \\
\text { Change }\end{array}$ & Discussion \\
\hline $\begin{array}{c}\text { Fig. } 6 \\
\text { [Fig. 6] }\end{array}$ & $\begin{array}{l}\text { The table in the latest version includes dimensions } \\
\text { for the length of the weld bead. A note has been } \\
\text { added to the table in the latest version which } \\
\text { indicates that the length of the weld bead is not } \\
\text { critical as long as the crack-starter notch is at the } \\
\text { center of the specimen and that the weld bead does } \\
\text { not contact the sample support structure when the } \\
\text { specimen is fully deflected. None of this } \\
\text { information is present in the table within the cited } \\
\text { version. }\end{array}$ & 1 & $\begin{array}{l}\text { The table in the latest version includes information } \\
\text { that is not included in the cited version. This } \\
\text { information involved the specification of the length } \\
\text { of the weld bead, along with tolerances for that } \\
\text { parameter. There has also been a footnote added to } \\
\text { the table which indicates that the length of the weld } \\
\text { bead is not critical as long as the bead meets certain } \\
\text { criteria. The changes add new information and } \\
\text { criteria to the latest version of the standard. }\end{array}$ \\
\hline
\end{tabular}




\section{RECOMMENDATIONS}

This part of the comparison summarizes significant differences (identified in Part II) between the cited and latest versions of the standard and addresses their effects on the citing documents. Those changes in the standard that added detail to existing requirements are not included in the summary of significant differences. The regulatory citations to ASTM E208 (identified in Part I) are evaluated based on the significant differences between the cited and latest versions of this standard. Citations in the SRP are evaluated first, followed by citations in associated

Regulatory Guides and 10 CFR sections. Recommendations concerning the updating of these citations as they relate to the SRP-UDP are also included in this part of the comparison.

\section{Summary of Significant Differences}

Examples of significant changes are a new requirement to abandon the two-pass welding procedure and replace it with a preferred single-pass procedure, the prohibition of repair welding in the latest version, the prohibition of welding with a weaving (oscillating) motion in the latest version, an apparent erroneous exclusion of provisions for cast bars in the latest version, changes in weld electrodes permitted for use with the standard, a new procedure and new criteria in the latest version for reporting fracture test results, new criteria for determining the validity of test performance, and new requirements for weld bead length and length tolerances.

ASTM E208-1991 does not appear to have any changes that would cause it to be unacceptable to replace ASTM E208-1969 as the standard method for conducting drop-weight tests to determine the nil-ductility transition temperature of ferritic steel.

\section{SRP Citations to the Standard}

\section{Section 5.2.3, Rev. 2, "Reactor Coolant Pressure Boundary Materials" (July 1981)}

Consideration should be given for SRP Section 5.2.3 to reference ASTM E208-1991, "Standard Test Method for Conducting Drop-Weight Test to Determine Nil-Ductility Transition Temperature of Ferritic Steels" as a replacement for the unspecified version citation to ASTM E208. This recommendation is subject to NRC review and analysis of the identified significant changes. 
Recommendations for updating specific references in SRP Section 5.2.3 are as follows:

SRP Section 5.2.3

Paragraph

$\underline{\text { Recommendation }}$

Reference 7

Replace the reference to ASTM E-208 with ASTM E208-1991, "Standard Test Method for Conducting Drop-Weight Test to Determine NilDuctility Transition Temperature of Ferritic Steels."

Section 5.3.2, Rev. 1, "Pressure-Temperature Limits" (July 1981)

Subject to NRC analysis of the identified significant differences, consideration should be given to replace the citation of ASTM E208 in Branch Technical Position MTEB 5-2 with ASTM E208-1991. Recommendations for updating specific references in SRP Section 5.3.2 are as follows:

SRP Section 5.3.2

Paragraph $\quad$ Recommendation

B. Branch Technical Replace the reference to ASTM E-208 with ASTM E208-1991. Position

Section 5.4.1.1, Rev. 1, "Pump Flywheel Integrity" (July 1981)

Subject to NRC analysis of the identified significant differences, consideration should be given to replace the citation of ASTM E208-1969 with ASTM E208-1991 in SRP Section 5.4.1.1. Recommendations for updating specific references in SRP Section 5.4.1.1 are as follows:

SRP Section 5.4.1.1

Paragraph

$\underline{\text { Recommendation }}$

II. Acceptance

Replace the reference to "ASTM E-208" with "ASTM E208-1991."

Criteria

Reference 3

Replace the reference to ASTM E-208-69 with ASTM E208-1991, "Standard Test Method for Conducting Drop-Weight Test to Determine NilDuctility Transition Temperature of Ferritic Steels," Annual Book of ASTM Standards, American Society for Testing and Materials. 
Section 10.2.3, Rev. 1, "Turbine Disk Integrity" (July 1981)

Subject to NRC analysis of the identified significant differences, consideration should be given to replace the citation of ASTM E208 with ASTM E208-1991 in SRP Section 10.2.3. Recommendations for updating specific references in SRP Section 10.2.3 are as follows:

SRP Section 10.2.3

Paragraph

II. Acceptance

Criteria

Reference 3

None

\section{Recommendation}

Replace the reference to "ASTM E-208" with "ASTM E208-1991."

Replace the reference to ASTM E-208 with ASTM E208-1991, "Standard Test Method for Conducting Drop-Weight Test to Determine NilDuctility Transition Temperature of Ferritic Steels," Annual Book of ASTM Standards, American Society for Testing and Materials.

\section{Other Regulatory Citations to the Standard}


Section 3

\section{PROBLEMATIC COMPARISONS}




\subsection{ASTM Standard D1587 Comparison}

This section presents a comparison of the version of ASTM D1587 cited in the Standard Review Plan (SRP) and associated Regulatory Guides and Code of Federal Regulation (CFR) sections with the latest version of the standard, in support of the Nuclear Regulatory Commission's (NRC's) Standard Review Plan Update and Development Program (SRP-UDP).

\section{CITED STANDARD:}

ASTM D1587-1967, "Standard Method for Thin-Walled Tube Sampling of Soils"

\section{LATEST STANDARD:}

ASTM D1587-1983, "Standard Practice for Thin-Walled Tube Sampling of Soils". Subsequent to the completion of this comparison, ASTM issued a 1994 version of the standard. The 1994 version will be considered as potential future work.

\section{CONTENTS}

Page

I. REGULATORY CITATIONS $\ldots \ldots \ldots \ldots \ldots \ldots \ldots \ldots \ldots \ldots \ldots \ldots \ldots \ldots \ldots \ldots \ldots \ldots \ldots \ldots \ldots \ldots \ldots \ldots \ldots \ldots .1-2$

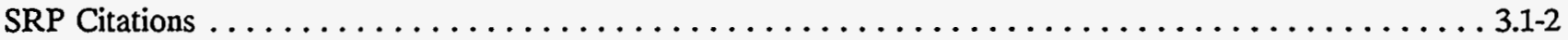

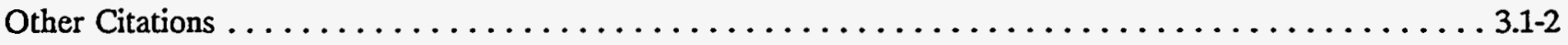

Regulatory Guide $1.132 \ldots \ldots \ldots \ldots \ldots \ldots \ldots \ldots \ldots \ldots \ldots \ldots \ldots \ldots \ldots \ldots \ldots \ldots \ldots \ldots \ldots \ldots \ldots .1-2$

II. CITED VS. LATEST STANDARD DIFFERENCES $\ldots \ldots \ldots \ldots \ldots \ldots \ldots \ldots \ldots \ldots \ldots \ldots \ldots \ldots \ldots \ldots \ldots .1-2$

III. RECOMMENDATIONS $\ldots \ldots \ldots \ldots \ldots \ldots \ldots \ldots \ldots \ldots \ldots \ldots \ldots \ldots \ldots \ldots \ldots \ldots \ldots \ldots \ldots \ldots \ldots \ldots \ldots \ldots \ldots .1-15$

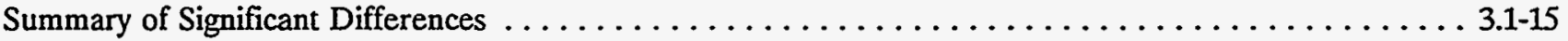

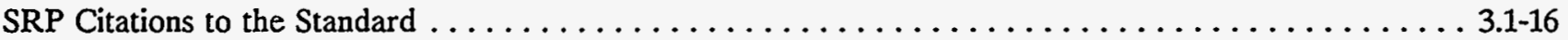

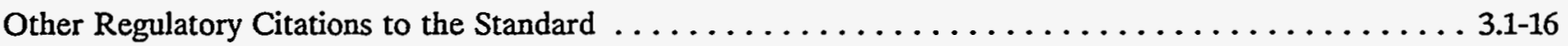




\section{REGULATORY CITATIONS}

This part of the comparison identifies specific citations to ASTM D1587 in the SRP and associated Regulatory Guides and 10 CFR sections. Recommendations on the disposition of these citations based on the results of this standard comparison are presented in Part III, Recommendations.

\section{SRP Citations}

None

\section{Other Citations}

\section{Regulatory Guide 1.132}

Revision/Title: Rev. 1, March 1979, "Site Investigations for Foundations of Nuclear power Plants"

Location: Regulatory Guide 1.132 cites ASTM D1587-1967 in subsection C, "Regulatory Position" and as Reference 13 in the Reference subsection in Appendix D.

Context: ASTM D1587 is cited for specifications of boring tubes for sampling soils. Regulatory Guide 1.132 provides additional requirements that are not provided in ASTM D1587. Regulatory Guide 1.132 is cited as an Acceptance Criterion in SRP Sections 2.5.1, 2.5.2, 2.5.3, 2.5 .4 and 2.5.5 for the development of site specific investigative programs and the conduct of subsurface investigations, the spacing and depth of borings and sampling.

\section{CITED VS. LATEST STANDARD DIFFERENCES}

This part of the comparison presents those changes from the cited version (1967) to the latest version (1983) identified for ASTM D1587. Many of these changes involve formatting, editorial and grammatical differences. Others involve clarification (e.g., the addition of a figure or illustration) and have no effect on requirements. Those differences between the cited and latest versions of ASTM D1587 which are judged to be significant and warranted further investigation relative to the technical and regulatory effects of their citation in regulatory documents are tabulated and discussed on the following pages. 
To facilitate review and consideration of their effects on ASTM D1587 citations in regulatory documents, significant differences between the cited and latest versions are classified into the following change types:

1. new or changed requirements affecting established NRC positions and requirements,

2. new or changed requirements not addressed by established NRC positions and requirements,

3. new or changed requirements allowing more flexibility,

4. deleted or relaxed requirements, and

5. new or changed requirements adding detail to established NRC regulatory positions.

Further consideration of the effects of the changes presented in this section on the SRP and associated Regulatory Guides and CFR sections that cite ASTM D1587 is provided in the Part II, Recommendations, of this section. Those differences classified as change types 1-4 are summarized in Part $\mathrm{MI}$. 


\begin{tabular}{|c|c|c|c|}
\hline \multicolumn{3}{|c|}{$\begin{array}{l}\text { PROBLEMATIC } \\
\text { COMPARISONS }\end{array}$} & \multirow[b]{2}{*}{ NCES: ASTM D1587 } \\
\hline \multicolumn{3}{|c|}{ CITED VS. LATEST STANDARD DIFFERENCES: ASTM D1587 } & \\
\hline $\begin{array}{l}\frac{\text { Section }}{\text { cited \& }} \\
\text { [latest] }\end{array}$ & $\begin{array}{c}\text { Significant Changes } \\
\text { cited \& [latest] }\end{array}$ & $\begin{array}{l}\text { Type of } \\
\text { Change } \\
\end{array}$ & Discussion \\
\hline $\begin{array}{c}1 \\
{[1]}\end{array}$ & $\begin{array}{l}\text { The } 1967 \text { version indicated that, in general, open- } \\
\text { tube samplers and piston samplers are the two } \\
\text { types of samplers that use thin-walled tubes; piston } \\
\text { samplers are better and can be used in almost all } \\
\text { soils; and that since the thin-walled tube } \\
\text { requirements are the same for both types of } \\
\text { samples, the method described applies equally to } \\
\text { both. The } 1983 \text { version states that "thin-walled } \\
\text { tubes used in piston, plug, or rotary-type samplers } \\
\text { such as the Denison or Pitcher, must comply with } \\
\text { the portions of this practice which describe the } \\
\text { thin-walled tubes (5.3)." }\end{array}$ & 3 & $\begin{array}{l}\text { The types of samplers were increased from open- } \\
\text { tube and piston samplers in the } 1967 \text { version to } \\
\text { piston, plug, or rotary-type samplers in the } 1983 \\
\text { version. The changes to the } 1983 \text { version that } \\
\text { address additional types of samplers increase the } \\
\text { scope of the standard, and thus, may allow for use of } \\
\text { samplers not previously addressed by the } 1967 \\
\text { version. }\end{array}$ \\
\hline $\begin{array}{c}\text { None } \\
{[\text { Note 1] }}\end{array}$ & $\begin{array}{l}\text { NOTE } 1 \text { that this practice does not apply to liners } \\
\text { used within the above samplers was added to the } \\
1983 \text { version. }\end{array}$ & 3 & $\begin{array}{l}\text { The added note in the } 1983 \text { version that this practice } \\
\text { does not apply to liners used within samplers limits } \\
\text { the applicability of the requirements of the standard. }\end{array}$ \\
\hline $\begin{array}{c}\text { None } \\
{[2]}\end{array}$ & $\begin{array}{l}\text { Practices D 2488, "Practice for Description and } \\
\text { Identification of Soils (Visual-Manual Procedure)," } \\
\text { D 3550, "Practice for Ring-Lines Barrel Sampling } \\
\text { of Soils), and D 4220, "Practices for Preserving and } \\
\text { Transporting Soil Samples" were listed in the } 1983 \\
\text { version as applicable documents. Footnote } 2 \text { was } \\
\text { added to indicate the volume number of the } \\
\text { Annual Book of ASTM Standards containing the } \\
\text { applicable standards. }\end{array}$ & 1 & $\begin{array}{l}\text { The implementation of new practices by reference to } \\
\text { D } 2488 \text {, D 2550, and D } 4220 \text { appears to be a } \\
\text { significant change, because reference of these } \\
\text { practices may introduce additional requirements. } \\
\text { Regulatory review is needed to determine the } \\
\text { consequences of implementing these practices to the } \\
\text { regulatory citation in Regulatory Guide } 1.132 \text {. }\end{array}$ \\
\hline
\end{tabular}




\begin{tabular}{|c|c|c|c|}
\hline \multicolumn{4}{|c|}{ CITED VS. LATEST STANDARD DIFFERENCES: ASTM D1587 } \\
\hline $\begin{array}{l}\text { Section } \\
\text { cited \& } \\
\text { [latest] }\end{array}$ & $\begin{array}{c}\text { Significant Changes } \\
\text { cited \& [latest] }\end{array}$ & $\begin{array}{l}\text { Type of } \\
\text { Change }\end{array}$ & $\begin{array}{c}\cdot \\
\text { Discussion }\end{array}$ \\
\hline $\begin{array}{c}2.1 \\
{[5.1,5.2]}\end{array}$ & $\begin{array}{l}\text { "Before insertion of the thin-walled tube" was } \\
\text { deleted from the } 1967 \text { version. A permissive in the } \\
1967 \text { version that any drilling equipment may be } \\
\text { used that can affect continuous and rapid } \\
\text { penetration of the tube into the sampled soil" was } \\
\text { changed to "and that does not hinder the } \\
\text { penetration of the thin-walled sampler" in Section } \\
5.1 \text { and to a requirement in Section } 5.2 \text { that } \\
\text { sampler insertion equipment shall be adequate to } \\
\text { provide a relatively rapid continuous penetration } \\
\text { force. "Open borehole diameter and the inside } \\
\text { diameter of driven casing or hollow stem auger } \\
\text { shall not exceed } 3.5 \text { times the outside diameter of } \\
\text { the thin-walled tube" was added to the } 1983 \\
\text { version. }\end{array}$ & 1 & $\begin{array}{l}\text { The new specification that open borehole diameter } \\
\text { and inside diameter of driven casing or hollow stem } \\
\text { auger shall not exceed } 3.5 \text { times the outside diameter } \\
\text { of the thin-walled tube imposes a new requirement. } \\
\text { The other changes appear to be reorganization of } \\
\text { material that do not affect requirements. }\end{array}$ \\
\hline
\end{tabular}




\begin{tabular}{|c|c|c|c|}
\hline \multicolumn{3}{|c|}{$\begin{array}{l}\text { PROBLEMATIC } \\
\text { COMPARISONS }\end{array}$} & Section 3 \\
\hline \multicolumn{4}{|c|}{ CITED VS. LATEST STANDARD DIFFERENCES: ASTM D1587 } \\
\hline $\begin{array}{l}\text { Section } \\
\text { cited \& } \\
\text { [latest] }\end{array}$ & $\begin{array}{c}\text { Significant Changes } \\
\text { cited \& [latest] }\end{array}$ & $\begin{array}{l}\text { Type of } \\
\text { Change }\end{array}$ & Discussion \\
\hline $\begin{array}{c}2.2 \\
{[5.3]}\end{array}$ & $\begin{array}{l}\text { The mm equivalent for tube sizes in inches was } \\
\text { deleted, "Any materials having adequate strength } \\
\text { and resistance to corrosion will be satisfactory" was } \\
\text { changed to "metal having adequate strength for use } \\
\text { in the soil and formation intended," the } \\
\text { requirement for the inside clearance ratio in the } \\
1967 \text { version to be between } 0.5 \text { and } 3 \text { percent was } \\
\text { changed to } 1 \% \text { or as specified by the engineer or } \\
\text { geologist for the soil and formation to be sampled, } \\
\text { and requirements for a length to diameter ratio } \\
\text { between five and ten to be available for penetration } \\
\text { into sands and between ten and fifteen for } \\
\text { penetration into clays was moved to subsection } 6.4 \\
\text { in the } 1983 \text { version with additional requirements } \\
\text { for determining the length of advance by the } \\
\text { resistance and condition of the formation. The } \\
1983 \text { version added a comment that the inside } \\
\text { clearance ratio should increase with the increase of } \\
\text { the plasticity of the soil. } \\
\text { A requirement in the } 1967 \text { version for tubes to be } \\
\text { round and smooth, without bumps, dents, or } \\
\text { scratches and clean, and free from rust and dirt } \\
\text { was changed to tubes shall be clean and free of all } \\
\text { (Cont'd) }\end{array}$ & 1 & $\begin{array}{l}\text { The } 1983 \text { version adds requirements for determining } \\
\text { the length of advance by the resistance and condition } \\
\text { of the formation; changes a requirement for the } \\
\text { inside clearance ratio to be changed from between } \\
0.5 \text { and } 3 \text { percent to } 1 \% \text {; adds a comment that the } \\
\text { inside clearance ratio should increase with the } \\
\text { increase in plasticity of the soil; recommends that } \\
\text { tubes should have protective coating; requires tubes } \\
\text { storing samples stored for over } 72 \text { hours to be } \\
\text { coated; allows lubricating oil, lacquer, epoxy, Teflon, } \\
\text { plating, alternate base metals, and other coatings; } \\
\text { and requires the engineer or geologist to specify the } \\
\text { type of coating. These changes offer new provisions } \\
\text { and add new requirements for the manufacture and } \\
\text { application of thin wall tubes. It should be noted } \\
\text { that Regulatory Guide } 1.132 \text { provides separate } \\
\text { criteria for the inside clearance ratio in C.6.d. }\end{array}$ \\
\hline
\end{tabular}




\begin{tabular}{|c|c|c|c|}
\hline \multicolumn{4}{|c|}{ CITED VS. LATEST STANDARD DIFFERENCES: ASTM D1587 } \\
\hline $\begin{array}{l}\text { Section } \\
\text { cited \& } \\
\text { [latest] }\end{array}$ & $\frac{\text { Significant Changes }}{\text { cited \& [latest] }}$ & $\begin{array}{l}\text { Type of } \\
\text { Change }\end{array}$ & Discussion \\
\hline $\begin{array}{c}2.2 \\
{[5.3]} \\
\text { (Cont'd) }\end{array}$ & $\begin{array}{l}\text { surface irregularities in the } 1983 \text { version. The } 1967 \\
\text { version indicated that corrosion resistance can be } \\
\text { provided by a suitable coating, and that sizes other } \\
\text { than these may be used, if specified. The } 1983 \\
\text { version recommends that tubes should have } \\
\text { protective coating to prevent damage to the tube } \\
\text { and the sample; requires tubes storing samples } \\
\text { stored for over } 72 \text { hours to be coated; allows } \\
\text { lubricating oil, lacquer, epoxy, Teflon, plating, } \\
\text { alternate base metals, and other coatings; and } \\
\text { requires the engineer or geologist to specify the } \\
\text { type of coating. }\end{array}$ & & \\
\hline $\begin{array}{l}2.2 .2 \\
{[5.4]}\end{array}$ & $\begin{array}{l}\text { The } 1967 \text { version requires two } 9.1 \mathrm{~mm} \text { vent holes in } \\
\text { the sampler head, and a } 3.9 \mathrm{~cm}^{2} \text { vent in the } \\
\text { coupling head check valve. The } 1983 \text { version } \\
\text { requires the sampler head to contain a suitable } \\
\text { check valve and a venting area equal to or greater } \\
\text { than the area through the check valve. Attachment } \\
\text { of the head to the tube is required to be concentric } \\
\text { and coaxial. }\end{array}$ & 3 & $\begin{array}{l}\text { The requirements in the } 1967 \text { version for two } 9.1 \\
\text { mm vent holes in the sampler head and a } 3.9 \mathrm{~cm}^{2} \\
\text { vent in the coupling head check valve were changed } \\
\text { in the } 1983 \text { version for the sampler head to contain a } \\
\text { suitable check valve, for a venting area equal to or } \\
\text { greater than the area through the check valve, and } \\
\text { for the attachment of the head to the tube to be } \\
\text { concentric and coaxial. These changes in } \\
\text { requirements in the } 1983 \text { version affect specifications } \\
\text { for venting through the sampler head. }\end{array}$ \\
\hline
\end{tabular}


PROBLEMATIC

\begin{tabular}{|c|c|c|c|}
\hline \multicolumn{4}{|c|}{ CITED VS. LATEST STANDARD DIFFERENCES: ASTM D1587 } \\
\hline $\begin{array}{l}\frac{\text { Section }}{\text { cited \& }} \\
\text { [latest] }\end{array}$ & $\frac{\text { Significant Changes }}{\text { cited \& [latest] }}$ & $\begin{array}{l}\text { Type of } \\
\text { Change }\end{array}$ & Discussion \\
\hline $\begin{array}{c}2.3 \\
{[\text { None] }}\end{array}$ & $\begin{array}{l}\text { The } 1967 \text { version specifies the requirements for } \\
\text { wax and other components for sealing the sample } \\
\text { tubes. These requirements were not carried } \\
\text { forward to the } 1983 \text { version. }\end{array}$ & 4 & $\begin{array}{l}\text { The requirements in the } 1967 \text { version for wax and } \\
\text { other components were not carried forward to the } \\
1983 \text { version. This change in requirements affects } \\
\text { the methods used to seal the ends of the sample } \\
\text { tubes. }\end{array}$ \\
\hline $\begin{array}{l}\text { None } \\
{[5.3]}\end{array}$ & $\begin{array}{l}\text { The } 1983 \text { version refers to Table } 1 \text { and Subsection } \\
6.4 \text { for tube lengths, and to Table } 2 \text { for tolerances. }\end{array}$ & 1 & $\begin{array}{l}\text { These new sections in the } 1983 \text { version provide } \\
\text { guidance for locating and imposing requirements for } \\
\text { tube lengths and tolerances. }\end{array}$ \\
\hline $\begin{array}{l}\text { None } \\
\text { [Table] }\end{array}$ & $\begin{array}{l}\text { Table } 2 \text { was added to the } 1983 \text { version to describe } \\
\text { dimensional tolerances. }\end{array}$ & 1 & $\begin{array}{l}\text { The addition of dimensional tolerances to the } 1983 \\
\text { version imposes new fabrication, procurement, and } \\
\text { inspection requirements. }\end{array}$ \\
\hline $\begin{array}{c}3.2 \\
{[6.2]}\end{array}$ & $\begin{array}{l}\text { "The use of" and "The procedure of" were deleted } \\
\text { in the } 1983 \text { version. "Shall not be allowed" was } \\
\text { changed to "are/is not permitted" in two places; } \\
\text { "any Side discharge bit is permitted" was changed } \\
\text { to "Side discharge bits may be used, with caution;" } \\
\text { and "hole" was changed to "borehole to sampling } \\
\text { elevation." Instructions to remove loose material } \\
\text { from the center of a casing or hollow stem auger } \\
\text { as carefully as possible to avoid disturbance of the } \\
\text { material to be sampled were added to the } 1983 \\
\text { version. }\end{array}$ & 1 & $\begin{array}{l}\text { Instructions added to the } 1983 \text { version to remove } \\
\text { loose material from the center of a casing or hollow } \\
\text { stem auger provide new requirements. This change } \\
\text { appears to be consistent with requirements in } \\
\text { Regulatory Guide } 1.132 \text { in Section C.6. }\end{array}$ \\
\hline
\end{tabular}




\begin{tabular}{|c|c|c|c|}
\hline \multicolumn{4}{|c|}{ CITED VS. LATEST STANDARD DIFFERENCES: ASTM D1587 } \\
\hline $\begin{array}{l}\text { Section } \\
\text { cited \& } \\
\text { [latest] }\end{array}$ & $\begin{array}{c}\text { Significant Changes } \\
\text { cited \& [latest] }\end{array}$ & $\begin{array}{l}\text { Type of } \\
\text { Change }\end{array}$ & Discussion \\
\hline $\begin{array}{c}\text { None } \\
\text { [Note 2] }\end{array}$ & $\begin{array}{l}\text { NOTE } 2 \text { was added to the } 1983 \text { version to indicate } \\
\text { that roller bits are available in downward-jetting } \\
\text { and diffused-jet configurations. Downward-jetting } \\
\text { configuration rock bits are not acceptable. Diffuse- } \\
\text { jet configurations are generally acceptable. }\end{array}$ & 1 & $\begin{array}{l}\text { A new note added to the } 1983 \text { version to indicate } \\
\text { that roller bits are available in downward-jetting and } \\
\text { diffused-jet configurations appears to be significant, } \\
\text { because the note imposes a new requirement that } \\
\text { downward-jetting configuration rock bits are not } \\
\text { acceptable, while diffuse-jet configurations are } \\
\text { generally acceptable. }\end{array}$ \\
\hline $\begin{array}{c}3.4 \\
{[6.5} \\
\text { Note 4] }\end{array}$ & $\begin{array}{l}\text { "Soils are so hard" was changed to "Formation is } \\
\text { too hard." Provisions to use Practice D } 3550 \text { or } \\
\text { other methods, as directed by the engineer or } \\
\text { geologist, were added in the } 1983 \text { version. An } \\
\text { instruction to turn the tube at least two revolutions } \\
\text { to shear the sample off at the end before pulling } \\
\text { was moved to NOTE } 4 \text { in the } 1983 \text { version. } \\
\text { Numerous editorial word changes were made. }\end{array}$ & 1 & $\begin{array}{l}\text { The added provisions to use Practice D } 3550 \text { or } \\
\text { other methods as directed by the engineer or } \\
\text { geologist in the } 1983 \text { version appear to impose new } \\
\text { requirements. }\end{array}$ \\
\hline $\begin{array}{c}3.5 \\
\text { [None] }\end{array}$ & $\begin{array}{l}\text { An instruction in the } 1967 \text { version to repeat the } \\
\text { sampling procedures at intervals not longer than } 5 \\
\mathrm{ft} \text { in homogeneous strata and at every change in } \\
\text { strata was not carried forward into the } 1983 \\
\text { version. }\end{array}$ & 4 & $\begin{array}{l}\text { The omission of an instruction in the } 1983 \text { version to } \\
\text { repeat the sampling procedures at intervals not } \\
\text { longer than } 5 \mathrm{ft} \text { in homogeneous strata and at every } \\
\text { change in strata affects requirements for sampling. } \\
\text { However, it should be noted that Regulatory Guide } \\
1.132 \text { provides independent specifications for } \\
\text { sampling depth intervals in B.6. }\end{array}$ \\
\hline
\end{tabular}




\begin{tabular}{|c|c|c|c|}
\hline \multicolumn{4}{|c|}{$\begin{array}{l}\text { PROBLEMATIC } \\
\text { COMPARISONS } \\
\end{array}$} \\
\hline \multicolumn{4}{|c|}{ CITED VS. LATEST STANDARD DIFFERENCES: ASTM D1587 } \\
\hline $\begin{array}{l}\text { Section } \\
\text { cited \& } \\
\text { [Iatest] }\end{array}$ & $\begin{array}{c}\text { Significant Changes } \\
\text { cited \& [latest] }\end{array}$ & $\begin{array}{l}\text { Type of } \\
\text { Change } \\
\end{array}$ & Discussion \\
\hline $\begin{array}{c}4.1,4.4 \\
{[7.1]}\end{array}$ & $\begin{array}{l}\text { Editorial changes include deletion of "sampler," } \\
\text { "and also the length penetrated," "before applying } \\
\text { wax, and "of sample." A requirement to remove at } \\
\text { least } 1 \text { in. of material from the lower end of the } \\
\text { tube for soil description and make a careful } \\
\text { description giving composition, condition, color } \\
\text { and, if possible, structure and consistency in the } \\
1967 \text { version was changed to provide a description } \\
\text { of the soil in accordance with Practice D } 2488 \text { in } \\
\text { the } 1983 \text { version. The detailed description of the } \\
\text { final sealing and preparation of the ends for } \\
\text { shipping in the } 1967 \text { version was modified to } \\
\text { provide increased emphasis on performance } \\
\text { requirements in the } 1983 \text { version. New } \\
\text { requirements to measure the overall sample length } \\
\text { and alternatively to seal the tube without removal } \\
\text { of soil from the ends of the tube, if so directed by } \\
\text { the engineer or geologist, were added to the } 1983 \\
\text { version. }\end{array}$ & 1 & $\begin{array}{l}\text { The requirement to make a careful description of } \\
\text { the soil in the } 1967 \text { version was changed to a } \\
\text { requirement to provide a description of the soil in } \\
\text { accordance with Practice D } 2488 \text { in the } 1983 \text { version; } \\
\text { a requirement for a detailed description in the } 1967 \\
\text { version of the final sealing and preparation of the } \\
\text { ends was changed to an instruction to provide } \\
\text { increased emphasis on performance oriented } \\
\text { requirements in the } 1983 \text { version; and new } \\
\text { requirements were added in the } 1983 \text { version to } \\
\text { measure the overall sample length and alternatively } \\
\text { to seal the tube without removal of soil from the } \\
\text { ends of the tube, if so directed by the engineer or } \\
\text { geologist. These impose new and changed } \\
\text { requirements for soil analysis and sample } \\
\text { preparation. }\end{array}$ \\
\hline $\begin{array}{c}\text { None } \\
\text { [Note 5] }\end{array}$ & $\begin{array}{l}\text { A note was added to the } 1983 \text { version to permit } \\
\text { field extrusion and packaging of extruded samples } \\
\text { under the specific direction of a geotechnical } \\
\text { engineer or geologist. }\end{array}$ & 3 & $\begin{array}{l}\text { The note added to the } 1983 \text { version to permit field } \\
\text { extrusion and packaging of extruded samples under } \\
\text { the specific direction of a geotechnical engineer or } \\
\text { geologist appears to introduce new provisions. }\end{array}$ \\
\hline
\end{tabular}




\begin{tabular}{|c|c|c|c|}
\hline \multicolumn{4}{|c|}{ CITED VS. LATEST STANDARD DIFFERENCES: ASTM D1587 } \\
\hline $\begin{array}{l}\text { Section } \\
\text { cited \& } \\
\text { [latest] }\end{array}$ & $\frac{\text { Significant Changes }}{\text { cited \& [latest] }}$ & $\begin{array}{l}\text { Type of } \\
\text { Change }\end{array}$ & Discussion \\
\hline $\begin{array}{c}\text { None } \\
{[\text { Note 6] }}\end{array}$ & $\begin{array}{l}\text { A note was added that tubes sealed over the ends } \\
\text { as opposed to those sealed with expanding packers } \\
\text { should contain end padding in end voids in order } \\
\text { to prevent drainage or movement of the sample } \\
\text { within the tube. }\end{array}$ & 1 & $\begin{array}{l}\text { The note added to the } 1983 \text { version that tubes sealed } \\
\text { over the ends, as opposed to those sealed with } \\
\text { expanding packers, should contain end padding in } \\
\text { end voids to prevent drainage or shifting of the } \\
\text { sample adds a new recommendation. }\end{array}$ \\
\hline $\begin{array}{c}4.2 \\
{[7.2]}\end{array}$ & $\begin{array}{l}\text { The detailed procedures in the } 1967 \text { version to } \\
\text { label the sample tubes were changed to functional } \\
\text { requirements to affix labels or apply markings as } \\
\text { necessary to identify the sample and assure survival } \\
\text { during transportation and storage. }\end{array}$ & 3 & $\begin{array}{l}\text { The change from a detailed procedure in the } 1967 \\
\text { version for labeling sample tubes to a functional } \\
\text { requirement for identification of samples in the } 1983 \\
\text { version may affect labeling practice. }\end{array}$ \\
\hline $\begin{array}{c}4.3 \\
\text { [None] }\end{array}$ & $\begin{array}{l}\text { Requirements to prevent freezing and extreme } \\
\text { temperatures and to ship samples protected with } \\
\text { resilient packing material to reduce shock, } \\
\text { vibration, and disturbance were not carried over to } \\
\text { the } 1983 \text { version. }\end{array}$ & 4 & $\begin{array}{l}\text { The omission of requirements to prevent freezing } \\
\text { and extreme temperatures, and to protect samples } \\
\text { with resilient packing material during shipping may } \\
\text { affect preparation, storage, and shipping procedures. }\end{array}$ \\
\hline $\begin{array}{c}5.1 \\
{[8.1]}\end{array}$ & $\begin{array}{l}\text { The requirement in the } 1967 \text { version for the boring } \\
\text { data to be recorded in the field and include the } \\
\text { following was changed to the appropriate } \\
\text { information is required as follows in the } 1983 \\
\text { version. }\end{array}$ & 4 & $\begin{array}{l}\text { The omission of the requirement in the } 1983 \text { version } \\
\text { for boring data to be recorded in the field could } \\
\text { affect the procedure for recording the boring data. }\end{array}$ \\
\hline
\end{tabular}




\begin{tabular}{|c|c|c|c|}
\hline \multicolumn{4}{|c|}{$\begin{array}{l}\text { PROBLEMATIC } \\
\text { COMPARISONS }\end{array}$} \\
\hline \multicolumn{4}{|c|}{ CITED VS. LATEST STANDARD DIFFERENCES: ASTM D1587 } \\
\hline $\begin{array}{l}\text { Section } \\
\text { cited \& } \\
\text { [latest] }\end{array}$ & $\frac{\text { Significant Changes }}{\text { cited \& [latest] }}$ & $\begin{array}{l}\text { Type of } \\
\text { Change }\end{array}$ & Discussion \\
\hline $\begin{array}{c}5.1 .4 \\
{[8.1 .3]}\end{array}$ & $\begin{array}{l}\text { "Surface elevation, if available" was changed to } \\
\text { "Surface elevation or reference to a datum." }\end{array}$ & 1 & $\begin{array}{l}\text { The change from "surface elevation" to "surface } \\
\text { elevation or reference to a datum" could be } \\
\text { significant if reference to a datum provides a } \\
\text { different level of precision or if surface elevation } \\
\text { were required for normalization of data during } \\
\text { analyses. }\end{array}$ \\
\hline $\begin{array}{r}5.1 .6 \\
{[8.1 .7} \\
8.1 .12 \\
8.1 .13]\end{array}$ & $\begin{array}{l}\text { "Method of advancing sampler, penetration and } \\
\text { recovery lengths" was changed to "Method of } \\
\text { sampler insertion: push or drive" and "Recovery: } \\
\text { length of sample obtained." "Length of sampler } \\
\text { advance" was added to the } 1983 \text { version. }\end{array}$ & 1 & $\begin{array}{l}\text { The change from documenting the method of } \\
\text { advancing the sampler in the } 1967 \text { version to a } \\
\text { choice of only "push or drive" in the } 1983 \text { version } \\
\text { reduces the number of possible choices. The } \\
\text { omission of guidance to document the penetration } \\
\text { length in the } 1983 \text { version could result in a loss of } \\
\text { information, and therefore appears to be a } \\
\text { significant change. The added requirement in the } \\
1983 \text { version for documenting the length of sampler } \\
\text { advance in the report provides additional } \\
\text { information. }\end{array}$ \\
\hline $\begin{array}{c}5.1 .7 \\
{[8.1 .6]}\end{array}$ & $\begin{array}{l}\text { "Type and size of sampler" was changed to } \\
\text { "Description of sampler: size, type of metal, type } \\
\text { of coating." }\end{array}$ & 1 & $\begin{array}{l}\text { The change in provisions for documentation from } \\
\text { "type of sampler" in the } 1967 \text { version to "type of } \\
\text { metal" in the } 1983 \text { version limits the options in type } \\
\text { of sampler. The added provision for documenting } \\
\text { the type of coating in the } 1983 \text { version added new } \\
\text { information to be documented. }\end{array}$ \\
\hline
\end{tabular}




\begin{tabular}{|c|c|c|c|}
\hline \multicolumn{4}{|c|}{ CITED VS. LATEST STANDARD DIFFERENCES: ASTM D1587 } \\
\hline $\begin{array}{l}\text { Section } \\
\text { cited \& } \\
\text { [latest] }\end{array}$ & $\begin{array}{c}\text { Significant Changes } \\
\text { cited \& [latest] }\end{array}$ & $\begin{array}{l}\text { Type of } \\
\text { Change }\end{array}$ & Discussion \\
\hline $\begin{array}{c}5.1 .8 \\
{[8.1 .11]}\end{array}$ & $\begin{array}{l}\text { "Description of soil" was changed to "Soil } \\
\text { description in accordance with Practice D 2488." }\end{array}$ & 1 & $\begin{array}{l}\text { The added instruction to describe the soil in } \\
\text { accordance with Practice D } 2488 \text { adds a new } \\
\text { requirement. }\end{array}$ \\
\hline $\begin{array}{c}5.1 .9 \\
{[\text { None] }}\end{array}$ & $\begin{array}{l}\text { "Thickness of layer" was not carried over in the } \\
1983 \text { version. }\end{array}$ & 4 & $\begin{array}{l}\text { The omission of a requirement to document layer } \\
\text { thickness in the } 1983 \text { version could result in a loss of } \\
\text { information. }\end{array}$ \\
\hline $\begin{array}{l}5.1 .10 \\
{[8.1 .9]}\end{array}$ & $\begin{array}{l}\text { "Depth to water surface; to loss of water; to } \\
\text { artesian head; time at which reading was made" } \\
\text { was changed to "Depth to groundwater level: date } \\
\text { and time measured." }\end{array}$ & 1 & $\begin{array}{l}\text { The change from "depth to water surface" to "depth } \\
\text { to groundwater level" is an editorial change. The } \\
\text { omission of "to loss of water; to artesian head" could } \\
\text { result in a loss of information. The added } \\
\text { requirement to document the date in the } 1983 \\
\text { version provides additional information for the } \\
\text { report. }\end{array}$ \\
\hline $\begin{array}{c}5.1 .11 \\
\text { [None] }\end{array}$ & $\begin{array}{l}\text { "Type and make of machine" was not carried over } \\
\text { in the } 1983 \text { version. }\end{array}$ & 4 & $\begin{array}{l}\text { The omission of the requirements to document the } \\
\text { type and make of machine in the } 1983 \text { version could } \\
\text { result in a loss of information. }\end{array}$ \\
\hline $\begin{array}{l}5.1 .12 \\
{[8.1 .8]}\end{array}$ & $\begin{array}{l}\text { "Size of casing, depth of cased hole" was changed } \\
\text { to "Method of drilling, size of hole, casing, and } \\
\text { drilling fluid used" in the } 1983 \text { version. }\end{array}$ & 1 & $\begin{array}{l}\text { The added requirements in the } 1983 \text { version to } \\
\text { document the method of drilling and the drilling } \\
\text { fluid used, provides additional information. }\end{array}$ \\
\hline $\begin{array}{c}5.1 .13 \\
\text { [None] }\end{array}$ & $\begin{array}{l}\text { "Names of crewmen" was not carried over in the } \\
1983 \text { version. }\end{array}$ & 4 & $\begin{array}{l}\text { The deletion of the names of crewmen from the } \\
\text { report in the } 1983 \text { version could result in a loss of } \\
\text { information. }\end{array}$ \\
\hline
\end{tabular}




\begin{tabular}{|c|l|c|c||}
\hline \multicolumn{4}{|c|}{ CITED VS. LATEST STANDARD DIFFERENCES: ASTM D1587 } \\
\hline $\begin{array}{c}\text { Section } \\
\text { cited \& } \\
\text { [latest] }\end{array}$ & \multicolumn{1}{|c|}{$\begin{array}{c}\text { Significant Changes } \\
\text { cited \& [latest] }\end{array}$} & $\begin{array}{c}\text { Type of } \\
\text { Change }\end{array}$ & \multicolumn{1}{c||}{ Discussion } \\
\hline $\begin{array}{c}5.1 .14 \\
\text { [None] }\end{array}$ & $\begin{array}{l}\text { "Weather, remarks" was not carried over in the } \\
1983 \text { version. }\end{array}$ & 4 & $\begin{array}{l}\text { The deletion of provisions in the 1983 version for } \\
\text { documenting the weather and remarks could result } \\
\text { in a loss of information. }\end{array}$ \\
\hline $\begin{array}{c}\text { None } \\
\text { 8.1.10] }\end{array}$ & $\begin{array}{l}\text { "Any possible current or tidal effect on water level" } \\
\text { was added to the 1983 version. }\end{array}$ & 1 & $\begin{array}{l}\text { The added requirements in the 1983 version for } \\
\text { documenting any possible current or tidal effect on } \\
\text { water level provides additional information. }\end{array}$ \\
\hline
\end{tabular}




\section{RECOMMENDATIONS}

This part of the comparison summarizes significant differences (identified in Part II) between the cited and latest versions of the standard and addresses their effects on the citing documents. Those changes in the standard that added detail to existing requirements are not included in the summary of significant differences. The regulatory citations to ASTM D1587 (identified in Part I) are evaluated based on the significant differences between the cited and latest versions of this standard. Citations in the SRP are evaluated first, followed by citations in associated Regulatory Guides and 10 CFR sections. Recommendations concerning the updating of these citations as they relate to the SRP-UDP are also included in this part of the comparison.

\section{Summary of Significant Differences}

The recommendations which follow are contingent upon NRC analysis of the apparently significant differences identified. Examples of significant changes that are an increase in requirements are an increase in the number of recommended types of tube samplers; implementation of new ASTM practices; a new specification for the ratio of the borehole inside diameter to the outside diameter of the thin-walled tube; new requirements for determining the length of tube sampler advance; a new requirement for tubes storing samples longer than 72 hours to be coated; a new requirement for the engineer or geologist to specify the coating type; a change in requirements for vent hole size in the sampler head and in the coupling head check valve; new guidance for locating and imposing requirements for tube lengths and tolerances; new instructions to remove loose material from the center of a casing or hollow stem auger; a new rejection of downwardjetting configuration rock bits and endorsement of diffuse-jet configurations; the added instruction to describe the soil in accordance with ASTM Practice D 2488; an increased emphasis on performance oriented requirements for sealing sampler ends; a new permissive for field extrusion and packaging of extruded samples under the specific direction of a geotechnical engineer or geologist; new requirements for maintaining identification of tube samples; and additional reporting requirements.

Examples of significant changes that are decreased requirements are an exclusion of the practice to liners; a deletion of requirements for wax for sealing the ends of sample tubes; the deletion of an instruction to repeat the sampling procedures at intervals not longer than $5 \mathrm{ft}$ in homogeneous strata and at every change in strata; the deletion of requirements to prevent exposure of samples to freezing and extreme temperatures; the omission of the requirement for boring data to be recorded in the field; and the omission of guidance to record the type and make of machine, layer thickness, penetration length, weather, and names of crewmen in the report.

While detailed analysis is beyond the scope of the Standard Review Plan Update Project, ASTM D1587-1983 does not appear to have any changes that would cause it to be unacceptable to replace ASTM D1587-1967 for boring tube specifications and as a reference in Regulatory Guide 1.132. Most of the changes involve increased requirements. Changes that reduce requirements (such as the deletion of the requirement to repeat the sampling procedures at intervals not longer than 5 feet is already covered in Regulatory Guide 1.132 in Section C.6 where requirements for sampling depth intervals are specified) tend to be covered 
separately by requirements in Regulatory Guide 1.132. The relaxation of the minimum inside clearance ratio from 0.5 to $1 \%$ does not appear to be significant, because Regulatory Guide 1.132 specifies requirements for the inside clearance ratio in C.6.d. Regulatory Guide 1.132 specifies other guidelines in B.4.b(2) and C.6 that are not included in ASTM D1587.

NRC review is needed to determine the acceptability of the identified changes that appear to be significant. Pending this review, consideration should be given for Regulatory Guide 1.132 to reference ASTM D15871983, "Standard Practice for Thin-Walled Tube Sampling of Soils," as a replacement for ASTM D1587-1967, "Standard Method for Thin-Walled Tube Sampling of Soils."

SRP Citations to the Standard

None

\section{Other Regulatory Citations to the Standard}

Regulatory Guide 1.132, Rev. 1, "Site Investigations for Foundations of Nuclear Power Plants" (March 1979)

Recommendations for updating specific references in Regulatory Guide 1.132 are as follows:

Regulatory Guide

1.132 Paragraph

Recommendation

c.6.a.

Revise to: "a. Tubes should meet the specifications of ASTM Standard D 1587-83 (Ref. 13);"

Reference 13

Replace the reference to ASTM D1587-1967 with ASTM D 1587-1983, "Standard Practice for Thin-Walled Tube Sampling of Soils." 


\subsection{ASTM Standard D3286 Comparison}

This section presents a comparison of the version of ASTM D3286 cited in the Standard Review Plan (SRP) and associated Regulatory Guides and Code of Federal Regulation (CFR) sections with the latest version of the standard, in support of the Nuclear Regulatory Commission's (NRC's) Standard Review Plan Update and Development Program (SRP-UDP).

\section{CITED STANDARD:}

ASTM D3286-1973, "Standard Method of Test for Gross Calorific Value of Solid Fuel by the Isothermal-Jacket Bomb Calorimeter"

\section{LATEST STANDARD:}

ASTM D3286-1991a, "Standard Test Method of Test for Gross Calorific Value of Coal and Coke by the Isoperibol Bomb Calorimeter"

\section{CONTENTS}

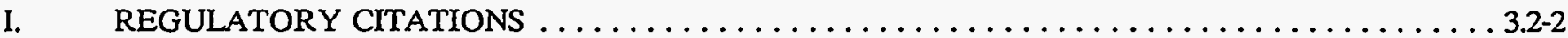

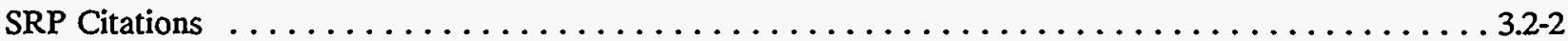

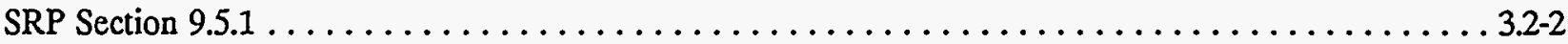

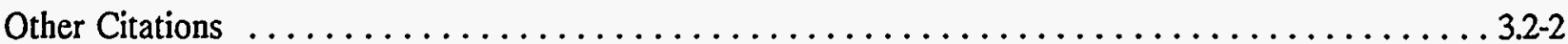

Regulatory Guide $1.120 \ldots \ldots \ldots \ldots \ldots \ldots \ldots \ldots \ldots \ldots \ldots \ldots \ldots \ldots \ldots \ldots \ldots \ldots \ldots \ldots \ldots \ldots \ldots .2-2$

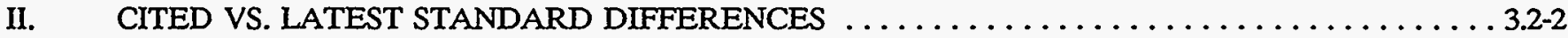

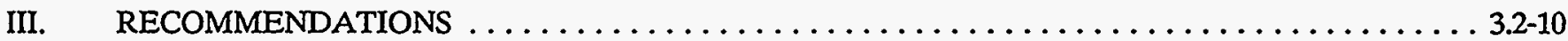

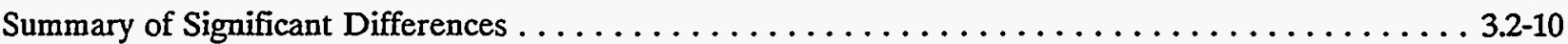

SRP Citations to the Standard . . . . . . . . . . . . . . . . . . . . . . . . 3.2-11

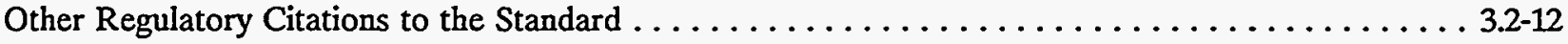




\section{REGULATORY CITATIONS}

This part of the comparison identifies specific citations to ASTM D3286 in the SRP and associated Regulatory Guides and 10 CFR sections. Recommendations on the disposition of these citations based on the results of this standard comparison are presented in Part III, Recommendations.

\section{SRP Citations}

\section{SRP Section 9.5.1}

Revision/Title: Rev. 3, July 1981, "Fire Protection Program"

Location: ASTM D3286-1973 is cited in Branch Technical Position CMEB 9.5-1 "Guidelines for Fire Protection for Nuclear Power Plants under "References."

Context: ASTM D3286-1973 is cited as a reference.

\section{Other Citations}

\section{Regulatory Guide 1.120}

Revision/Title: Rev. 1, November, 1977, "Fire Protection Guidelines for Nuclear Power Plants"

Location: Regulatory Guide 1.120 cites ASTM D3286-1973 in C.4.a.(4)(b) and in "References" under Other Documents."

Context: ASTM D3286 is cited by Regulatory Guide 1.120 for a method of test to be used by a nationally recognized testing laboratory to verify that the potential heat release of interior finishes is $3500 \mathrm{Btu} / \mathrm{lb}$ or less.

\section{CITED VS. LATEST STANDARD DIFFERENCES}

This part of the comparison presents those changes from the cited version (ASTM D3286-1973) to the latest version (ASTM D3286-1991a) identified for ASTM D3286. Many of these changes involve formatting, editorial and grammatical differences. Others involve clarification (e.g., the addition of a figure or illustration) and have no effect on requirements. Those differences between the cited and latest version of ASTM D3286 which are judged to be significant and warranted further investigation relative to the technical and regulatory effects of their citation in regulatory documents are tabulated and discussed on the following pages. 
To facilitate review and consideration of their effects on ASTM D3286 citations in regulatory documents, significant differences between the cited and latest versions are classified into the following change types:

1. new or changed requirements affecting established NRC positions and requirements,

2. new or changed requirements not addressed by established NRC positions and requirements,

3. new or changed requirements allowing more flexibility,

4. deleted or relaxed requirements, and

5. new or changed requirements adding detail to established NRC regulatory positions.

Further consideration of the effects of the changes presented in this section on the SRP and associated Regulatory Guides and CFR sections that cite ASTM D3286 is provided in the Part II, Recommendations, of this section. Those differences classified as change types 1-4 are summarized in Part III. 


\begin{tabular}{|c|c|c|c|}
\hline \multicolumn{4}{|c|}{$\begin{array}{l}\text { PROBLEMATIC } \\
\text { COMPARISONS }\end{array}$} \\
\hline \multicolumn{4}{|c|}{ CITED VS. LATEST STANDARD DIFFERENCES: ASTM D3286 } \\
\hline $\begin{array}{l}\frac{\text { Section }}{\text { cited \& }} \\
\text { [latest] }\end{array}$ & $\frac{\text { Significant Changes }}{\text { cited \& [latest] }}$ & $\begin{array}{l}\text { Type of } \\
\text { Change }\end{array}$ & Discussion \\
\hline $\begin{array}{l}\text { Title } \\
\text { [Title] }\end{array}$ & $\begin{array}{l}\text { Word changes in the title were "Method of Test" to } \\
\text { Test Method," "Solid Fuel" to "Coal and Coke" and } \\
\text { "Isothermal-Jacket" to "Isoperibol." }\end{array}$ & 1 & $\begin{array}{l}\text { The terms "isothermal-jacket" and "isoperibol" are } \\
\text { interchangeable. Therefore, this change is not } \\
\text { significant. However, the change from "solid fuel" to } \\
\text { "coal and coke" reduces the applicability of using the } \\
\text { 1991a version of ASTM D } 3286 \text { for testing for the } \\
\text { calorific value of interior finishes specified in } \\
\text { C.4.a.(4)(b) of Reg. Guide 1.120. }\end{array}$ \\
\hline $\begin{array}{c}1.1 \\
{[1.1]}\end{array}$ & $\begin{array}{l}\text { Changes are "solid fuel" to "coal and coke" and } \\
\text { isothermal-jacket" to "isoperibol." }\end{array}$ & 1 & $\begin{array}{l}\text { The change from "solid fuel" to "coal and coke" in the } \\
\text { scope of the 1991a version reduces the applicability } \\
\text { of using the 1991a version of ASTM D3286 for } \\
\text { testing for the calorific value of interior finishes } \\
\text { specified in C.4.a.(4)(b) of Reg. Guide } 1.120 \text {. }\end{array}$ \\
\hline
\end{tabular}




\begin{tabular}{|c|c|c|c|}
\hline \multicolumn{4}{|c|}{ CITED VS. LATEST STANDARD DIFFERENCES: ASTM D3286 } \\
\hline $\begin{array}{l}\text { Section } \\
\text { cited \& } \\
\text { [latest] }\end{array}$ & $\begin{array}{c}\text { Significant Changes } \\
\text { cited \& [latest] }\end{array}$ & $\begin{array}{l}\text { Type of } \\
\text { Change } \\
\end{array}$ & Discussion \\
\hline $\begin{array}{c}2.1 \\
{[2.1]}\end{array}$ & 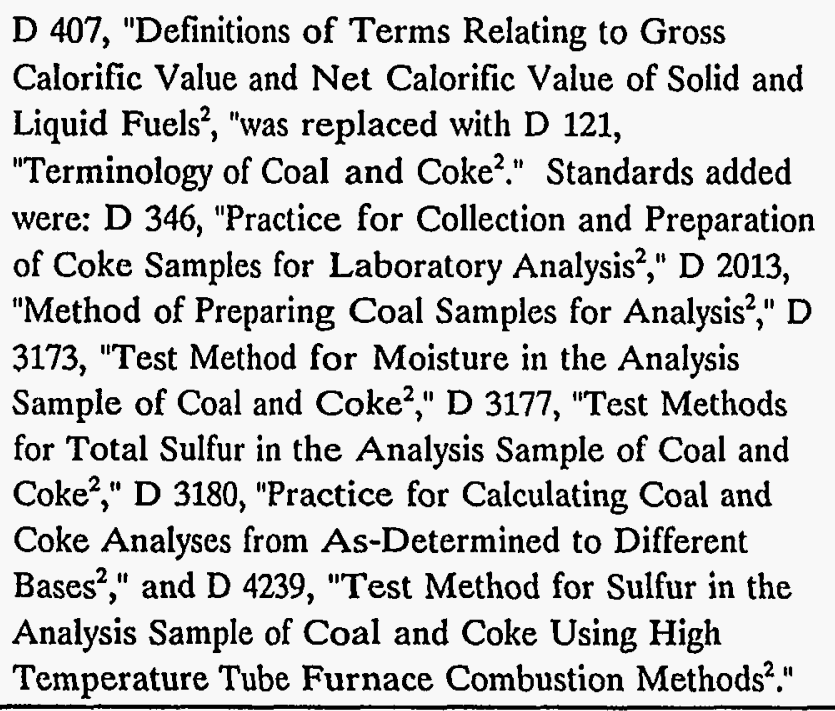 & 1 & $\begin{array}{l}\text { The changes in the referenced ASTM standards } \\
\text { reflect a change in applicability of the standard from } \\
\text { testing solid and liquid fuels to testing coal and coke } \\
\text { for calorific value. This change in the scope for the } \\
\text { 1991a version reduces the applicability of using the } \\
\text { 1991a version of ASTM D3286 for testing for the } \\
\text { calorific value of interior finishes specified in } \\
\text { C.4.a.(4)(b) of Reg. Guide 1.120. }\end{array}$ \\
\hline $\begin{array}{c}\text { Footnotes } \\
2-5 \\
\text { [Footnotes } \\
2-5]\end{array}$ & $\begin{array}{l}\text { The reference citations for Footnotes } 2 \text { through } 5 \\
\text { were updated. }\end{array}$ & 1 & $\begin{array}{l}\text { The references support the change in scope from } \\
\text { solid fuel to coal and coke and may therefore reduce } \\
\text { the applicability of using the 1991a version for testing } \\
\text { calorific value of interior finishes specified in } \\
\text { C.4.a.(4)(b) of Reg. Guide } 1.120 \text {. }\end{array}$ \\
\hline
\end{tabular}




\begin{tabular}{|c|c|c|c|}
\hline \multicolumn{4}{|c|}{$\begin{array}{l}\text { PROBLEMATIC } \\
\text { COMPARISONS } \\
\end{array}$} \\
\hline \multicolumn{4}{|c|}{ CITED VS. LATEST STANDARD DIFFERENCES: ASTM D3286 } \\
\hline $\begin{array}{l}\text { Section } \\
\text { cited \& } \\
\text { [latest] }\end{array}$ & $\frac{\text { Significant Changes }}{\text { cited \& [latest] }}$ & $\begin{array}{l}\text { Type of } \\
\text { Change }\end{array}$ & Discussion \\
\hline $\begin{array}{c}4.2 \\
{[3.1 .2]}\end{array}$ & $\begin{array}{l}\text { The brief definition of gross calorific value was } \\
\text { deleted, solid fuels was deleted, and } Q_{v} \text { was added. } \\
\text { The citation of D } 407 \text { for definitions was changed to } \\
\text { D } 121 \text { for terminology. }\end{array}$ & 1 & $\begin{array}{l}\text { The deletion of solid fuels and the change in citation } \\
\text { of D407, entitled "Definitions of Terms Relating to } \\
\text { Gross Calorific Value and Net Calorific Value of } \\
\text { Solid and Liquid Fuels," to D121, entitled } \\
\text { "Terminology of Coal and Coke," reduces the } \\
\text { applicability of using the } 1991 \text { a version of ASTM } \\
\text { D3286 for testing for the calorific value of interior } \\
\text { finishes specified in C.4.a.(4)(b) of Reg. Guide 1.120. }\end{array}$ \\
\hline $\begin{array}{c}\text { None } \\
{[5]}\end{array}$ & $\begin{array}{l}\text { This section describing the significance and use of the } \\
\text { gross calorific value is new with the 1991a version. }\end{array}$ & 1 & $\begin{array}{l}\text { The new section entitled "Significance and Use" } \\
\text { briefly describes what the test method is used for. } \\
\text { This new section primarily addresses testing of coal } \\
\text { and coke. This change may affect the applicability of } \\
\text { using the 1991a version of ASTM D3286 for testing } \\
\text { for the calorific value of interior finishes specified in } \\
\text { C.4.a.(4)(b) of Reg. Guide } 1.120 \text {. }\end{array}$ \\
\hline $\begin{array}{l}\text { None } \\
{[5.1]}\end{array}$ & $\begin{array}{l}\text { This section describes the business use of the gross } \\
\text { calorific value for coal and is new with the 1991a } \\
\text { version. }\end{array}$ & 1 & $\begin{array}{l}\text { The added description of the business use of the } \\
\text { gross calorific value for coal may affect the } \\
\text { applicability of using the 1991a version of ASTM } \\
\text { D3286 for testing for the calorific value of interior } \\
\text { finishes specified in C.4.a.(4)(b) of Reg. Guide 1.120. }\end{array}$ \\
\hline
\end{tabular}




\begin{tabular}{|c|c|c|c|}
\hline \multicolumn{4}{|c|}{ CITED VS. LATEST STANDARD DIFFERENCES: ASTM D3286 } \\
\hline $\begin{array}{l}\text { Section } \\
\text { cited \& } \\
\text { [latest] }\end{array}$ & $\frac{\text { Significant Changes }}{\text { cited \& [latest] }}$ & $\begin{array}{l}\text { Type of } \\
\text { Change }\end{array}$ & Discussion \\
\hline $\begin{array}{l}\text { None } \\
{[5.2]}\end{array}$ & $\begin{array}{l}\text { This section describes the regulatory use of the gross } \\
\text { calorific value for coal and is new with the 1991a } \\
\text { version. }\end{array}$ & 1 & $\begin{array}{l}\text { The added description of the regulatory use of the } \\
\text { gross calorific value for coal may affect the } \\
\text { applicability of using the 1991a version of ASTM } \\
\text { D3286 for testing for the calorific value of interior } \\
\text { finishes specified in C.4.a.(4)(b) of Reg. Guide 1.120. }\end{array}$ \\
\hline $\begin{array}{c}5.7 \\
{[6.9]}\end{array}$ & $\begin{array}{l}\text { "Firing" was changed to "Ignition" in two places; the } \\
\text { diameter and gage switched positions; Chromel C } \\
\text { alloy, iron, and palladium were added as acceptable } \\
\text { wire materials; and constant ignition wire mass was } \\
\text { added as a requirement. }\end{array}$ & 3 & $\begin{array}{l}\text { The identification of additional Chromel } C \text { alloy, } \\
\text { iron, and palladium wire materials that provide } \\
\text { results similar to platinum or nickel-chromium alloy } \\
\text { wire provides more materials options to the user. }\end{array}$ \\
\hline $\begin{array}{c}\text { None } \\
{[9]}\end{array}$ & $\begin{array}{l}\text { A description of the sample requirements with } \\
\text { citation of applicable standards was added. }\end{array}$ & 1 & $\begin{array}{l}\text { Addition of sample requirements with citation of } \\
\text { applicable standards for coal and coke may be } \\
\text { significant. This change in the scope for the 1991a } \\
\text { version reduces the applicability of using the 1991a } \\
\text { version of ASTM D } 3286 \text { for testing for the calorific } \\
\text { value of interior finishes specified in C.4.a.(4)(b) of } \\
\text { Reg. Guide 1.120. }\end{array}$ \\
\hline $\begin{array}{c}7.2 .5 \\
{[10.3 .5]}\end{array}$ & $\begin{array}{l}\text { Editorial changes were made, detail was added to the } \\
\text { text, reference to the analysis of coal or coke samples } \\
\text { is new, and the requirements appear to be more } \\
\text { restrictive in the 1991a version. }\end{array}$ & 1 & $\begin{array}{l}\text { The added reference to coal or coke samples reduces } \\
\text { the applicability of using the 1991a version of ASTM } \\
\text { D3286 for testing for the calorific value of interior } \\
\text { finishes specified in C.4.a.(4)(b) of Reg. Guide 1.120. }\end{array}$ \\
\hline $\begin{array}{c}\text { Note } 6 \\
\text { [Note 3] }\end{array}$ & $\begin{array}{l}\text { Note } 3 \text { in the } 1991 \text { a version adds palladium wire as a } \\
\text { material for which there is no correction provided the } \\
\text { ignition energy is constant. }\end{array}$ & 3 & $\begin{array}{l}\text { The addition of palladium wire as another acceptable } \\
\text { material increases the selection materials for the } \\
\text { user. }\end{array}$ \\
\hline
\end{tabular}




\begin{tabular}{|c|c|c|c|}
\hline \multicolumn{3}{|c|}{$\begin{array}{l}\text { PROBLEMATIC } \\
\text { COMPARISONS }\end{array}$} & \multirow[b]{2}{*}{ ICES: ASTM D3286 } \\
\hline \multicolumn{3}{|c|}{ CITED VS. LATEST STANDARD DIFFERENCES: ASTM D3286 } & \\
\hline $\begin{array}{l}\underline{\text { Section }} \\
\text { cited \& } \\
\text { [latest] }\end{array}$ & $\begin{array}{c}\text { Significant Changes } \\
\text { cited \& [latest] }\end{array}$ & $\begin{array}{l}\text { Type of } \\
\text { Change }\end{array}$ & Discussion \\
\hline $\begin{array}{c}8.1 \\
{[11.1]}\end{array}$ & $\begin{array}{l}\text { The second sentence regarding checking the energy } \\
\text { equivalent in the same manner as a routine fuel } \\
\text { sample in accordance with Section } 9 \text { was deleted in } \\
\text { the 1991a version. }\end{array}$ & 1 & $\begin{array}{l}\text { The deletion of the instruction regarding a routine } \\
\text { fuel sample in accordance with Section } 9 \text { reduces the } \\
\text { applicability of using the 1991a version of ASTM } \\
\text { D3286 for testing for the calorific value of interior } \\
\text { finishes specified in C.4.a.(4)(b) of Reg. Guide 1.120. }\end{array}$ \\
\hline $\begin{array}{c}9 \\
{[12]}\end{array}$ & "Solid Fuel" was changed to "Coal and Coke." & 1 & $\begin{array}{l}\text { The change from solid fuel to coal and coke reduces } \\
\text { the applicability of using the 1991a version of ASTM } \\
\text { D3286 for testing for the calorific value of interior } \\
\text { finishes specified in C.4.a.(4)(b) of Reg. Guide 1.120. }\end{array}$ \\
\hline $\begin{array}{c}9.1 \\
{[12.1]}\end{array}$ & $\begin{array}{l}\text { The 1991a version adds that the sample should be } \\
\text { thoroughly mixed in the sample bottle before it is } \\
\text { weighed and that each determination should be made } \\
\text { in accordance with the procedure described in } 10.3 .2 \\
\text { through 10.3.8. }\end{array}$ & 1 & $\begin{array}{l}\text { The new requirement for mixing the sample before it } \\
\text { is weighed into the sample holder provides for more } \\
\text { homogeneous samples and better reproducibility of } \\
\text { results. }\end{array}$ \\
\hline $\begin{array}{c}9.4 \\
{[12.4]}\end{array}$ & $\begin{array}{l}\text { Method D } 271 \text { was deleted and replaced with } \\
\text { Methods D } 3177 \text { or D } 4239 \text { for the determination of } \\
\text { the sulfur content of coal. }\end{array}$ & 1 & $\begin{array}{l}\text { The replacement of Method D } 271 \text { with Methods D } \\
3177 \text { or D } 4239 \text { is a refinement over the } 1973 \text { version } \\
\text { for determining the sulfur content of coal. }\end{array}$ \\
\hline $\begin{array}{l}\text { Note } 10 \\
\text { [None] }\end{array}$ & $\begin{array}{l}\text { Note } 10 \text { regarding the use of Method D } 271 \text { was } \\
\text { deleted for the 1991a version. }\end{array}$ & 1 & $\begin{array}{l}\text { The deletion of Note } 10 \text { regarding the use of Method } \\
\text { D } 271 \text { is consistent with the replacement of Method } \\
\text { D } 271 \text { with Methods D } 3177 \text { or D } 4239 \text { in the 1991a } \\
\text { version. }\end{array}$ \\
\hline
\end{tabular}




\begin{tabular}{|c|c|c|c|}
\hline \multicolumn{4}{|c|}{ CITED VS. LATEST STANDARD DIFFERENCES: ASTM D3286 } \\
\hline $\begin{array}{l}\frac{\text { Section }}{\text { cited \& }} \\
\text { [latest] }\end{array}$ & $\frac{\text { Significant Changes }}{\text { cited \& [latest] }}$ & $\begin{array}{l}\text { Type of } \\
\text { Change }\end{array}$ & Discussion \\
\hline $\begin{array}{c}\text { None } \\
{[15]}\end{array}$ & $\begin{array}{l}\text { Section } 15 \text { is new for the } 1991 \text { a version. It cites Test } \\
\text { Method D } 3171 \text { to evaluate moisture and Practice D } \\
3180 \text { to convert the calorific value to other bases. }\end{array}$ & 1 & $\begin{array}{l}\text { The addition of Section } 15 \text { citing Test Method D } \\
3171 \text { and Practice D } 3180 \text { reduce the applicability of } \\
\text { using the } 1991 \text { a version of ASTM D } 3286 \text { for testing } \\
\text { the calorific value of interior finishes specified in } \\
\text { C.4.a.(4)(b) of Reg. Guide } 1.120 \text {. }\end{array}$ \\
\hline $\begin{array}{c}11.1 \\
{[16.1]}\end{array}$ & $\begin{array}{l}\text { The word "for" and specification of } 250-\mu \mathrm{m} \text { (No. } 60 \text { ) } \\
\text { samples were added. }\end{array}$ & 1 & $\begin{array}{l}\text { The added granular size specification for the split } \\
\text { analysis samples to control moisture reduces the } \\
\text { variability in results caused by differences in moisture } \\
\text { contents. }\end{array}$ \\
\hline $\begin{array}{l}\mathrm{X} 2.3 .2 \\
{[\mathrm{XI} .2]}\end{array}$ & $\begin{array}{l}\text { The section was divided into two sections, the section } \\
\text { number was revised, cited section numbers were } \\
\text { revised, "Definitions D } 407 \text { " was changed to } \\
\text { "Terminology D } 121, \text { " "g" was changed to "grams," } \\
\text { kcal/mole were changed to } \mathrm{kJ} / \mathrm{mol} \text {, citation of NBS } \\
\text { Circular } 500 \text { was applied for the energy of formation } \\
\text { and the energy of reaction for } \mathrm{H}_{2} \mathrm{SO}_{4} \text { " } \mathrm{x} \text { " was } \\
\text { changed to "times," there were numerous editorial } \\
\text { changes, "g" was changed to "gas," and "l" was } \\
\text { changed to "liquid." }\end{array}$ & 1 & $\begin{array}{l}\text { The change from citing Definitions D } 407 \text { relating to } \\
\text { solid and liquid fuels in the } 1973 \text { version to } \\
\text { Terminology D } 121 \text { relating to coal and coke reflects } \\
\text { a change in applicability of the standard from testing } \\
\text { solid and liquid fuels to testing coal and coke for } \\
\text { calorific value. This change in the scope for the } \\
\text { 1991a version reduces the applicability of using the } \\
\text { 1991a version of ASTM D } 3286 \text { for testing for the } \\
\text { calorific value of interior finishes specified in } \\
\text { C.4.a.(4)(b) of Reg. Guide } 1.120 \text {. }\end{array}$ \\
\hline
\end{tabular}




\section{RECOMMENDATIONS}

This part of the comparison summarizes significant differences (identified in Part II) between the cited and latest versions of the standard and addresses their regulatory effects on the citing documents. Those changes in the standard that added detail to existing requirements are not included in the summary of significant differences. The regulatory citations to ASTM D3286 (identified in Part I) are evaluated based on the significant differences between the cited and latest versions of this standard. Citations in the SRP are evaluated first, followed by citations in associated Regulatory Guides and 10 CFR sections. Recommendations concerning the updating of these citations as they relate to the SRP-UDP are also included in this part of the comparison.

\section{Summary of Significant Differences}

The recommendations which follow are contingent upon NRC analysis of the apparently significant differences identified in the comparison. Standard ASTM D3286 - 1973, is only cited in the list of references in SRP Section 9.5.1, Branch Technical Position (BTP) CMEB 9.5-1 and is not cited or referenced within the text of the SRP or BTP. The cited version of the standard (ASTM D3286-1973) applies to calorific testing of solid fuel. The latest version of the standard (ASTM D3286-1991a) only applies to the testing of coal and coke. It appears that this change in scope associated with the latest version limits its applicability in the context of fire protection for nuclear power plants.

Significant changes that enhance the standard by improving clarity, increasing choices of equivalent materials, and increasing control over factors that affect the reproducibility of results are the addition of Chromel $\mathrm{C}$ alloy, iron, and palladium ignition wires; a new requirement for mixing the sample before it is weighed into the sample holder; and the added granular size specification for the split analysis samples to control moisture and thereby reduce the variability in results caused by differences in moisture contents. One very significant change is that the 1991a version of ASTM 3286 is applicable only to coal and coke. The 1973 version of ASTM D3286, referenced in SRP 9.5.1, is applicable to solid fuels.

Discussion with an author of ASTM D3286, indicated that the change from "solid fuel" to "coal and coke" reduces the applicability of using the 1991a version of ASTM D3286 for testing other materials. Test reports for materials other than coal or coke must carry a disclaimer regarding the use of this standard to determine the calorific value of materials other than coal or coke. If the next revision of SRP 9.5.1 were to cite the 1991a version of ASTM D3286, it should consider providing a disclaimer of applicability to materials other than coal and coke. 


\section{SRP Citations to the Standard}

Section 9.5.1, Rev. 3, "Fire Protection Program" (July 1981)

Pending NRC review of the apparently significant changes, consider deleting the reference to ASTM D3286-1973, based on the following:

SRP Section

9.5.1

Paragraph

\section{$\underline{\text { Recommendation }}$}

REFERENCES Updating BTP CMEB 9.5-1 to cite the latest version of the standard (ASTM D3286 - 1991a) is not recommended based on the change of applicability from solid fuels in the cited version to only coal and coke in the latest version. The existing citation of ASTM D3286 (1973) in the references of BTP CMEB 9.5-1 appears to have been carried over in the revision to the previous version of the BTP (BTP ASB 9.51). However, the text in BTP ASB 9.5-1 that was associated with the standard was deleted in BTP CMEB 9.5-1. This deleted text allowed alternatives to noncombustible interior finishes based in part on material heat release as determined using ASTM D3286 (1973). BTP CMEB 9.5-1 states that interior finishes should be non-combustible. Therefore, it is recommended that the reference to ASTM D3286 - 1973 be deleted from BTP CMEB 9.5-1, because the reference does not support any current positions or guidance contained within the BTP. 
Other Regulatory Citations to the Standard

Regulatory Guide 1.120, "Fire Protection Guidelines for Nuclear Power Plants" (November 1977)

Pending NRC review of the significant differences, recommendations for updating references in Regulatory Guide 1.120 regarding the citation of ASTM D3286 are as follows:

Regulatory Guide 1.120 Paragraph

C.4.a.(4)(b)

\section{$\underline{\text { Recommendation }}$}

The paragraph states that interior wall and structural components, thermal insulation materials, radiation shielding materials, and soundproofing should be noncombustible. Interior finishes should be noncombustible or listed by a nationally recognized testing laboratory such as Factory Mutual or Underwriters Laboratory, Inc., for:

(a) Surface flamespread rating of 50 or less when tested under ASTM E-84, and

(b) Potential heat release of $3500 \mathrm{Btu} / \mathrm{lb}$ or less when tested under ASTM D3286 or NFPA 259. /1/

Updating Regulatory Guide 1.120 to cite the latest version of the standard (ASTM D3286 - 1991a) is not recommended based on the change of applicability from solid fuels in the cited version to only coal and coke in the latest version. Regulatory Guide 1.120, Revision 1, was issued for comment in November 1977. If the NRC decides to revise Regulatory Guide 1.120 in the future, it is expected that the existing version of the Regulatory Guide would require considerable updating to reflect current regulatory positions and guidance that have been developed or evolved since the Regulatory Guide was issued. If such an update to Regulatory guide 1.120 occurs, consideration should be given to assessing the continued applicability of ASTM D3286 (1973) in light of more recent or updated standards such as NFPA 259, "Standard Test Method for Potential Heat of Building Materials." 


\subsection{ASTM Standard E11 Comparison}

This section presents a comparison of the version of ASTM E11 cited in the Standard Review Plan (SRP) and associated Regulatory Guides and Code of Federal Regulation (CFR) sections with the latest version of the standard, in support of the Nuclear Regulatory Commission's (NRC's) Standard Review Plan Update and Development Program (SRP-UDP).

\section{CITED STANDARD:}

ASTM E11-1970, "Standard Specification for Wire Cloth Sieves for Testing Purposes"

\section{LATEST STANDARD:}

ASTM E11-1987, "Standard Specification for Wire-Cloth Sieves for Testing Purposes"

\section{CONTENTS}

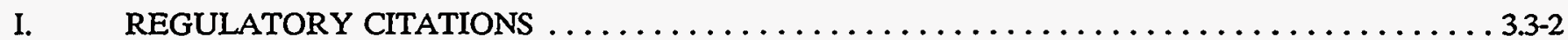

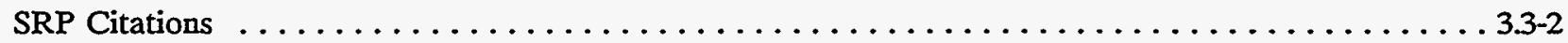

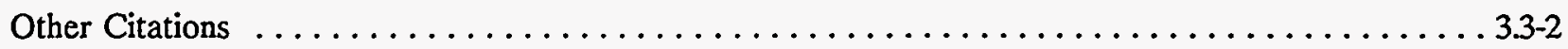

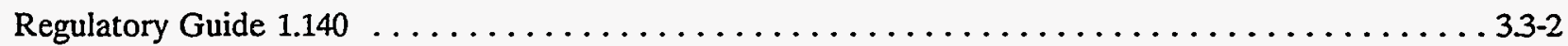

II. CITED VS. LATEST STANDARD DIFFERENCES $\ldots \ldots \ldots \ldots \ldots \ldots \ldots \ldots \ldots \ldots \ldots \ldots \ldots \ldots \ldots \ldots . .2$

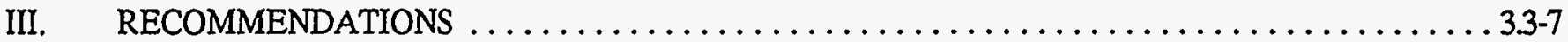

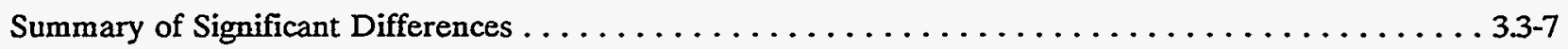

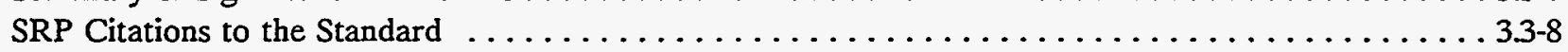

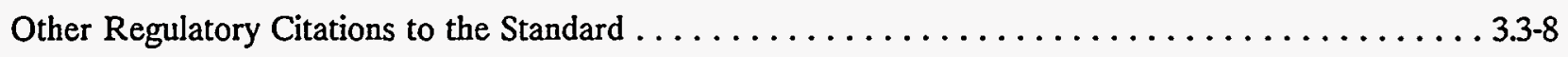




\section{REGULATORY CITATIONS}

This part of the comparison identifies specific citations to ASTM E11 in the SRP and associated Regulatory Guides and 10 CFR sections. Recommendations on the disposition of these citations based on the results of this standard comparison are presented in Part III, Recommendations.

\section{SRP Citations}

None

\section{Other Citations}

\section{Regulatory Guide $\mathbf{1 . 1 4 0}$}

Revision/Title: October, 1979, "Design, Testing, and Maintenance Criteria for Normal Ventilation Exhaust System Air filtration and Adsorption Units of Light-Water-Cooled Nuclear Power Plants."

Location: Regulatory Guide 1.140 cites ASTM E11-1970 in subsection C, "Regulatory Position."

Context: ASTM E11 is endorsed by Regulatory Guide 1.140 as acceptable specifications for wire cloth sieves for testing the particle size distribution of activated carbon. Regulatory Guide 1.140 is cited in the Acceptance Criteria and Review Procedures in SRP Section 11.3, "Gaseous Waste Management Systems," for the design, testing, and maintenance of normal ventilation exhaust systems. Acceptance criterion II.B.5 and Review Procedure III.5 deal specifically with design, testing and maintenance criteria for charcoal adsorbers in filtration systems.

\section{CITED VS. LATEST STANDARD DIFFERENCES}

This part of the comparison presents those changes from the cited version (1970) to the latest version (1987) identified for ASTM E11. Many of these changes involve formatting, editorial and grammatical differences. Others involve clarification (e.g., the addition of a figure or illustration) and have no effect on requirements. Those differences between the cited and latest versions of ASTM E-11 which are judged to be significant and warranted further investigation relative to the technical and regulatory effects of their citation in regulatory documents are tabulated and discussed on the following pages. 
To facilitate review and consideration of their effects on ASTM E11 citations in regulatory documents, significant differences between the cited and latest versions are classified into the following change types:

1. new or changed requirements affecting established NRC positions and requirements,

2. new or changed requirements not addressed by established NRC positions and requirements,

3. new or changed requirements allowing more flexibility,

4. deleted or relaxed requirements, and

5. new or changed requirements adding detail to established NRC regulatory positions.

Further consideration of the effects of the changes presented in this section on the SRP and associated Regulatory Guides and CFR sections that cite ASTM E11 is provided in the Part III, Recommendations, of this section. Those differences classified as change types 1-4 are summarized in Part III. 


\begin{tabular}{|c|c|c|c|}
\hline \multicolumn{4}{|c|}{ CITED VS. LATEST STANDARD DIFFERENCES: ASTM E11 } \\
\hline $\begin{array}{l}\text { Section } \\
\text { cited \& } \\
\text { [latest] }\end{array}$ & $\frac{\text { Significant Changes }}{\text { cited \& [latest] }}$ & $\begin{array}{l}\text { Type of } \\
\text { Change }\end{array}$ & $\begin{array}{c}\cdot \\
\text { Discussion }\end{array}$ \\
\hline $\begin{array}{l}\text { None } \\
{[2]}\end{array}$ & $\begin{array}{l}\text { This new section provides ASTM, Federal, Military, } \\
\text { and ISO Standard references. The ASTM } \\
\text { standards were included in notes in the } 1970 \\
\text { version. The references to Federal, Military, and } \\
\text { ISO standards are new in the } 1987 \text { version. The } \\
\text { new Section } 2 \text { introduces new Footnotes } 3 \text { through } \\
7 \text { to indicate where the standards are located or } \\
\text { their source of availability. }\end{array}$ & 1 & $\begin{array}{l}\text { The added references to standards ISO } 565 \text { for } \\
\text { opening sizes and ISO } 3310 / 1 \text { technical requirements } \\
\text { and testing metal wire cloth may be significant. } \\
\text { Discussion with the chairman of the ASTM E11 } \\
\text { standards committee on May } 2,1994 \text { indicated, } \\
\text { however, that the addition of these two references in } \\
\text { the } 1987 \text { version did not change the requirements } \\
\text { because the standard does not impose these } \\
\text { standards as requirements. Also the requirements of } \\
\text { these added standards appear to be consistent with } \\
\text { the requirements in the } 1970 \text { version of the standard. }\end{array}$ \\
\hline $\begin{array}{c}2.2 \\
{[3.2]}\end{array}$ & $\begin{array}{l}\text { Stainless steel was added as an acceptable material } \\
\text { for wire cloth in the } 1987 \text { version. }\end{array}$ & 3 & $\begin{array}{l}\text { The addition of stainless steel as an acceptable } \\
\text { material for wire cloth may be a significant change. } \\
\text { However, discussion with the chairman of the ASTM } \\
\text { E11 standards committee on May } 2,1994 \text { indicated } \\
\text { that stainless steel wire cloth has been used under } \\
\text { the materials category of "other suitable wire" prior } \\
\text { to the } 1987 \text { version. }\end{array}$ \\
\hline
\end{tabular}




\begin{tabular}{|c|c|c|c|}
\hline \multicolumn{4}{|c|}{ CITED VS. LATEST STANDARD DIFFERENCES: ASTM E11 } \\
\hline $\begin{array}{l}\frac{\text { Section }}{\text { cited \& }} \\
\text { [latest] }\end{array}$ & $\frac{\text { Significant Changes }}{\text { cited \& [latest] }}$ & $\begin{array}{l}\text { Type of } \\
\text { Change }\end{array}$ & Discussion \\
\hline $\begin{array}{l}3.4 \\
{[5.4]}\end{array}$ & $\begin{array}{l}\text { Restricted use of } 3 \text {-in. frames with openings larger } \\
\text { than } 150 \mu \mathrm{m} \text { (No. 100) was deleted. }\end{array}$ & 4 & $\begin{array}{l}\text { Removal of the restriction on the use of } 3 \text {-in. frames } \\
\text { for sieves with openings larger than } 150 \mu \mathrm{m} \text { (No. } \\
100 \text { ) appears to be a relaxation in requirements. } \\
\text { The sieve openings specified in Regulatory Guide } \\
1.140 \text { are larger than } 150 \mu \mathrm{m} \text { (No. } 100 \text { ). Discussion } \\
\text { with the chairman of the ASTM E11 standards } \\
\text { committee on May } 2,1994 \text { indicated that the } \\
\text { restrictions on } 3 \text {-in. sieves in the } 1970 \text { version were } \\
\text { too restrictive because the results from 3-in. sieves } \\
\text { should be similar to results using standard frames } \\
\text { for sieve sizes specified in Regulatory Guide } 1.140 \text {. } \\
\text { This difference appears to involve a relaxation in } \\
\text { requirements. }\end{array}$ \\
\hline $\begin{array}{l}\text { Appendix } \\
\text { A1 } \\
\text { [Appendix } \\
\text { XI] }\end{array}$ & $\begin{array}{l}\text { The } 1987 \text { version indicates that this appendix } \\
\text { provides "Nonmandatory Information." }\end{array}$ & 4 & $\begin{array}{l}\text { The addition of a note indicating that this appendix } \\
\text { provides nonmandatory information may be } \\
\text { significant. Discussion with the chairman of the } \\
\text { ASTM E11 standards committee on May 2, } 1994 \\
\text { indicated that the nonmandatory information note } \\
\text { would not change the methods of checking wire } \\
\text { cloth sieves for compliance. This difference appears } \\
\text { to involve a relaxation in requirements. }\end{array}$ \\
\hline
\end{tabular}




\begin{tabular}{||c|c|c|c||}
\hline \hline \multicolumn{5}{|c|}{ CITED VS. LATEST STANDARD DIFFERENCES: ASTM E11 } \\
\hline $\begin{array}{c}\text { Section } \\
\text { [latest] }\end{array}$ & \multicolumn{1}{|c|}{$\begin{array}{c}\text { Significant Changes } \\
\text { cited \& [latest] }\end{array}$} & $\begin{array}{l}\text { Type of } \\
\text { Change }\end{array}$ & \multicolumn{1}{|c|}{ Discussion } \\
\hline $\begin{array}{c}\text { A.1.1- } \\
\text { A.2.2 }\end{array}$ & $\begin{array}{l}\text { Detailed methods for using metrology to measure } \\
\text { and calculate the dimensional characteristics of } \\
\text { wire cloth sieves are provided by Appendix A1 in } \\
\text { XI.5.1] } \\
\text { the 1970 version. Appendix X1 in the 1987 version } \\
\text { does not include the detailed instruction on } \\
\text { metrology and concentrates more on the } \\
\text { acceptance criteria to determine if wire cloth sieves } \\
\text { conform to specification. }\end{array}$ & 1 & $\begin{array}{l}\text { Discussion with the chairman of the ASTM E11 } \\
\text { standards committee on May 2, 1994 indicated that } \\
\text { Appendix A1 of the 1970 version contained excessive } \\
\text { detail. The level of detail in Appendix X1 of the } \\
\text { 1987 version was reduced, but the requirements of } \\
\text { the standard were not changed. The regulatory } \\
\text { implications of the extensive changes in the appendix } \\
\text { may be significant, however. }\end{array}$ \\
\hline
\end{tabular}




\section{RECOMMENDATIONS}

This part of the comparison summarizes significant differences (identified in Part II) between the cited and latest versions of the standard and addresses their regulatory effects on the citing documents. Those changes in the standard that added detail to existing requirements are not included in the summary of significant differences. The regulatory citations to ASTM E11 (identified in Part I) are evaluated based on the significant differences between the cited and latest versions of this standard. Citations in the SRP are evaluated first, followed by citations in associated Regulatory Guides and 10 CFR sections. Recommendations concerning the updating of these citations as they relate to the SRP-UDP are also included in this part of the comparison.

\section{Summary of Significant Differences}

The recommendations which follow are contingent upon NRC analysis of the significant differences identified in this comparison. The following changes between the 1970 and 1987 versions of ASTM E11 appear to be significant: references to two ISO standards for opening sizes and technical requirements and testing metal wire cloth sieves were added, stainless steel was added as a suitable material for wire cloth, a restriction on the use of 3-in. sieve frames was deleted, and extensive changes were made to Appendix A1 with a new indication that it presents nonmandatory information.

The added references to standards ISO 565 for opening sizes and ISO 3310/1 technical requirements and testing metal wire cloth may be significant. Identifying the ramifications of adding these standards to the regulatory citation in Regulatory Guide 1.140 is beyond the scope of this review.

The addition of stainless steel wire as a cloth material appears to be a significant difference. However, stainless steel wire cloth has been used under the materials category of "other suitable wire" prior to the 1987 version.

The removal of the restriction on the use of 3-in. frames for sieves with openings larger that the $150 \mu \mathrm{m}$ (No. 100) appears to be a relaxation in requirements. The sieve openings specified in Regulatory Guide 1.140 are larger than $150 \mu \mathrm{m}$ (No. 100). Discussion with the chairman of the ASTM E11 standards committee indicated that the restrictions on 3-in. sieves in the 1970 version were too restrictive, because 3-in. sieves provide results comparable to those from standard frames for the sieve sizes specified in Regulatory Guide 1.140 .

The extensive changes to Appendix A1 may be significant. However, discussion with the chairman of the ASTM E11 standards committee indicated that the Appendix AI of the 1970 version contained excessive detail. The level of detail in.Appendix X1 of the 1987 version was reduced, but the requirements of the standard were not changed. 
The addition of a note indicating that Appendix A1 provides nonmandatory information may be significant. Because the 1970 version did not include the nonmandatory information note for Appendix A1, this change may have regulatory significance. NRC review is needed to determine the acceptability of this potentially significant change.

\section{SRP Citations to the Standard}

None

\section{Other Regulatory Citations to the Standard}

Regulatory Guide 1.140, Rev. 1, "Design, Testing, and Maintenance Criteria for Normal Ventilation Exhaust System Air filtration and Adsorption Units of Light-Water-Cooled Nuclear Power Plants" (October 1979)

NRC review is needed to determine the acceptability of the significant differences. Pending this review, consideration should be given to updating the citation of ASTM E11 from the 1970 to the latest 1987 version.

Regulatory Guide 1.140 Paragraph

C.3.g.

\section{$\underline{\text { Recommendation }}$}

The paragraph states that each original or replacement batch of impregnated activated carbon used in the absorber section should meet the qualification and batch test results summarized in Table 1 of this guide. In Table 1, the acceptable particle size distribution for new activated carbon is based on testing with wire cloth sieves per specifications in ASTM E11.

Even though the majority of the differences between the 1970 version and the 1987 version of ASTM E11 do not appear to be significant, the 1987 version provides additional detail in some areas, reduces excessive detail in some areas, and appears to reflect the latest industry practice. It appears that Regulatory Guide 1.140 would be enhanced by citing the latest (1987) version of ASTM E11 that is maintained by ASTM, subject to NRC review of the significant changes. 


\section{DISTRIBUTION}

No. Of

Copies

\section{OFFSITE}

U.S. Nuclear Regulatory Commission

$5 \quad$ Mr. Gene Suh

U.S. Nuclear Regulatory Commission Office of Nuclear Reactor Regulation

Mailstop O-12 E4

Washington, D.C. 20555

\section{ONSITE}

27 Pacific Northwest Laboratory

Mr. E. J. Cleary (20)

Information Release Office (7) 
8. PERFORMING ORGANIZATION - NAME AND ADDRESS (IINRC, provide Division, Ofice or Region, U.S. Nuclear Regulatory Commission, and malling address; if contractor, provide name and mailing address.)

Pacific Northwest Laboratory

Richland, WA 99352

9. SPONSORING ORGANIZATION - NAME AND ADDRESS (if NRC, type "Same as above"; if contractor, provide NRC Division, Office or Region, U.S. Nuclear Regulatory Commission, and mailing address.)

Division of Inspection and Support Programs

Office of Nuclear Reactor Regulation

U.S. Nuclear Regulatory Commission

Washington, DC 20555-0001

10. SUPPLEMENTARY

Gene Suh, NRC Project Manager

11. ABSTRACT (200 words or /ess)

This report provides the results of comparisons of the cited and latest versions of ASTM standards cited in the NRC Standard Review Plan for the Review of Safety Analysis Reports for Nuclear Power Plants (NUREG 0800) and related documents. The comparisons were performed by Battelle Pacific Northwest Laboratories in support of the NRC's Standard Review Plan Update and Development Program. Significant changes to the standards, from the cited version to the latest version, are described and discussed in a tabular format for each standard. Recommendations for updating each citation in the Standard Review Plan are presented. Technical considerations and suggested changes are included for related regulatory documents (i.e., Regulatory Guides and the Code of Federal Regulations) citing the standard. The results and recommendations presented in this document have not been subjected to NRC staff review.

12. KEY WORDSIDESCRIPTORS (List words or phrases that will assist researchers in locating the report)

Code, Standard, Standard Review Plan, SRP, American Society for Testing and Materials, ASTM

13. AVAILABILITY STATEMENT Unlimited

14. SECURITY CLASSIFICATION (This Page) Unclassified (This Report)

Unclassified

15. NUMBER OF PAGES

16. PRICE 
